\title{
Poznámky k problematice interiéru nezděných staveb středověkého Brna (konfrontace archeologických poznatků a mikromorfologické analýzy podlahových úrovní vybraných staveb)
}

\author{
Notes on the issues of the interior of non-masonry buildings in \\ medieval Brno (confrontation of archaeological findings and \\ a micromorphological study of floor levels of selected buildings)
}

- Lenka Lisá*, Petr Holub, Marek Peška, Antonín Zůbek -

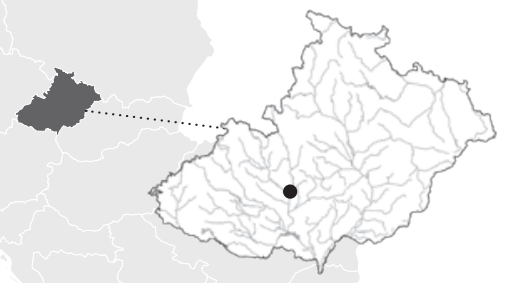

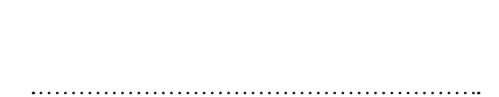

\section{KEYWORDS}

Micromorphology in an archaeological context - non-masonry architecture - formation processes - house maintenance - 13th-14th centuries

\section{ABSTRACT}

The study summarises the basic findings regarding non-masonry buildings in medieval Brno and the prospects for further knowledge. A modern methodological approach in the form of micromorphology in an archaeological context, particularly regarding the interiors of these buildings, was used to add more information. From more than 200 micromorphological samples taken in Brno since 2008, a total of 16 from five sites in the historical centre of the city were selected for this partial study. Temporally, this concerns the period between the early 13th and the mid-14th centuries. The basic outcome of the study is the analysis, interpretation and division of the samples into typological groups. Based on typical features, sunken parts of the structures used for a relatively long time could be divided from the above-ground structures even though in some cases the "floor sandwich" had been partly removed due to ongoing maintenance. Finally, the results were confronted with a macroscopic observation by an archaeologist and with ethnographic knowledge. It was possible to identify the more detailed microstratigraphy of the floor sandwiches than by macroscopic observations in most cases and therefore specify the interpretation of the origin of the floor sandwich.

\footnotetext{
* Corresponding author - E-mail address: lisa@gli.cas.cz
}

https://doi.org/10.47382/pv0622-06

Received 13 September 2021; received in revised form 30 November 2021. Available online 30 December 2021.

Copyright (c) 2021 Czech Acad Sci, Inst Archaeology Brno, and the authors. This is an open access article under the CC BY-NC-ND 4.0 license (https://creativecommons.org/licenses/by-nc-nd/4.0/).

Competing interests: The authors have declared that no competing interests exist.

\section{1. Úvod}

Nezděná architektura je jedním z nejvýraznějších témat v bádání o stavebním vývoji a charakteru zástavby středověkých měst. V českých zemích a širším středoevropském prostoru měla profánní zástavba stř̌edověkých měst v nejstarší fázi vývoje povětšinou nezděnou podobu. Zděné konstrukce se uplatňovaly u nejvýznamnějších městských budov, vstupních bran, hradeb a církevních objektů (kaplí, kostelů, klášterů) a jejich užití v běžné měštanské zástavbě bylo zpočátku spíše ojedinělé. Domy a stavby na samotných městištích byly dřevohliněné, teprve postupně docházelo k přeměně do zděné podoby. Žádná z těchto staveb se v našich zemích do dnešní doby nezachovala stojící a vzácně dochované části měštanských dřevohliněných staveb pochází až z období po třicetileté válce.

Přestože je otázka nejstarší měštanské zástavby jedním z nejzajímavějších badatelských témat v oblasti městské archeologie, dosud se jí u nás, na rozdíl od německého prostř̌edí, nedostalo odpovídajícího zájmu. Nejen v české, ale i v zahraniční archeologické literatuře prozatím až na výjimky postrádáme shrnutí poznatků o dřevohliněných stavbách v raných stř̌edoevropských městech, včetně obecnější analýzy dílčích témat jako jsou konstrukce, prostorová dispozice, chronologie atd. (z několika existujících regionálních přehledů a sborníků srovnej např. Brachmann, Klápště (eds.) 1996; Donat 2000; Gläser (ed.) 2001; Klápště (ed.) 2002; Küntzel 2010; Rębkowski 2001, 121-157; Schneider (ed.) 2012). Řada terénních poznatků navíc byla dosud zveřejněna nedostatečně, nebo vůbec. Problematiku se na základě publikovaných výsledků snažila uchopit monografie J. Piekalského z roku 2004 (Piekalski 2004). Převážně však jsou k dispozici pouze studie pozitivisticky prezentující celkové situace bez dalších interpretací a komentářů, a to většinou v rámci sumarizujících zpráv z jednotlivých výzkumů.

Zatímco obecné vymezení jednotlivých staveb, resp. jejich prostorovou dispozici a konstrukci, lze řešit běžnou interpretací výsledků terénních archeologických výzkumů s omezenou pomocí historických pramenů, ikonografí, analogií či etnologických poznatků (Holub et al. 2003), konkrétní využití odkrytých prostor, údržba a jejich životnost jsou stále předmětem dalších diskusí. Jde zejména o stanovení obytné či hospodářské funkce oddělených částí, nebo i celých objektů. Možnosti funkční interpretace daného objektu např. na základě jeho umístění na parcele má své limity, zejména proto, že máme povětšinou prozkoumány pouze výseky jednotlivých městišt s fragmenty někdejších staveb. Jasným dokladem někdejší obytné funkce tedy zůstává pouze prokázané otopné zařízení. V rámci př̀edkládané studie jsme se proto pokusili soustředit na studium podlahových souvrství. Ta byla, na rozdíl od zánikových zásypů, funkční součástí někdejších staveb a jsou dokladem jejich vývoje. Dosud jim však 
nebyla věnována významnější pozornost, a našim cílem bylo ověřit obecné možnosti jejich výpovědní hodnoty.

Dosud byla základem poznání podlahových souvrství makroskopická interpretace, která je však závislá na schopnostech jednotlivých archeologů empiricky vyhodnotit zvrstvení v interiéru. U takto posuzovaných vrstev však nelze s jistotou určit jejich původ. Některé z podlahových vrstev lze považovat za konstrukčníudusané přenesené podloží, jiné jsou proti tomu předmětem diskusí např. velmi tenké černé uhlíkaté vrstvičky (zašlapaný popel? spálené desky? atd.). Další skupinou jsou např. tenké rezavé vrstvy, u nichž se předpokládá, že by mohly mít organický původ, či šedé, často jílovité vrstvy, které mají zase množství laminárních komponent, a jsou obecně považovány za nášlapy. Nedílnou součástí podlahových souvrství jsou také zuhelnatělé či dřevěné fragmenty konstrukčních prvků, ke kterým se podlahy přimykají, či jsou jimi naopak narušeny. Jak je z výše uvedeného patrné, jsou stávající standardní postupy interpretace terénních situací velmi omezeny. Logickým krokem pro rozšíření našich znalostí a ověření dosavadních makroskopických interpretací jednotlivých vrstev je větší využití moderních metod v rámci př́rodních věd. Jde o podstatně komplexnější prrístup k vyhodnocení archeologických situací, rozšiřující stávající pozorování o řadu nových kvalit. Jedná se o mikroskopický pohled na dosud netušené detaily. Takový pohled přináší zejména ověření subjektivní a makroskopické interpretace vrstev a zásypů v terénu, a může zodpovědět či dále nastolit nové otázky. Standardně již dnes probíhá dendrochronologická analýza dřevěných či zuhelnatělých vzorků zajištující dataci odkrytých konstrukčních prvků, dále dendrologická analýza určující druh dřeviny, ale také archeobotanická a fosfátová analýza vzorků ze zásypů. V našich zemích je jedním z nejnovějších metodických přístupů využití mikromorfologie pro dokumentovaná archeologická zvrstvení. Tato metoda je ostatně již po dvě desetiletí součástí výzkumných standardů na archeologických lokalitách v zahraničí (Goldberg, Macphail 2006). V prrípadě předkládané studie byla právě mikromorfologie aplikována na studium sedimentárního archivu podlahových souvrství/horizontů, jež jsou nedílnou součástí obytného prostoru (Karkanas, Goldberg 2019), a to nejen ve stř̌edověku či novověku (Beran et al. 2013; Lisá et al. 2009; 2020a, b; Lisá, Kolař́ík 2020; Lisá, Lisý 2019). Podlahové horizonty a jejich význam pro interpretaci využití objektu byly v minulosti řešeny i v rámci pravěké archeologie (Macphail, Goldberg 2018; Karkanas 2006; Boivin 2000; Matthews 2005; Jarošová et al. 2010). Způsob jejich formování se lišil v závislosti na období, kulturních zvyklostech či regionu. Například podlahy vikingských domů byly vytvářeny cílenou akumulací vulkanického popela (Milek 2012). Dalším příkladem mohou být podlahy pravěkých a středověkých staveb na území Spojeného království, na jejichž použití jsou doloženy diatomové jíly a tilly (Macphail 1990). Nejdetailněji byly dosud studovány neolitické podlahy z tureckého Çatalhöyük (Boivin 2000; Matthews 2005).

Ve sprašových oblastech střední Evropy byla nejvhodnějším materiálem pro cílenou tvorbu podlahové stratigrafie spraš (Jarošová et al. 2010) nebo spraši podobný místní plavený materiál (Lisá et al. 2020a). Spraš je běžně používána jako konstrukční případně čistící (sanitární) materiál na dorovnávky povrchů, které jsou z nějakého důvodu znečištěny nebo morfologicky nevhodné. Obecně je takový, v tomto př́padě sprašový podlahový set s množstvím cíleně připravených podlah v literatuře označován jako konstruovaná podlaha (Macphail, Goldberg 2018; Karkanas, Goldberg 2019). Vedle toho vrstvičky, které vznikaly jako necílená akumulace (nášlapem), jsou v anglické literatuře označovány jako tzv. „beaten floors“ (Macphail et al. 2004). Thierry Gé se svými kolegy (Gé et al. 1993) představili mikromorfologický koncept, kterým lze podlahové horizonty popsat. Rozlišují celkem dvě, resp. tři zóny, které do sebe obvykle přecházejí. Báze podlahy je dle autorů tvořena tzv. pasivní vrstvou, což může být geologické podloží, starší kulturní vrstva, konstrukční část podlahy (např̀ přemístěná spraš) nebo materiál položený na podlaze (např. prkna). Pasivní vrstvou může být postsedimentárně vytvořena tzv. reakční vrstva, která v podstatě pouze deformuje pasivní zónu. Nejsvrchnější částí podlahového setu/sendviče je tzv. aktivní zóna, tvořená samotným nášlapem (Macphail, Goldberg 2018). To je však pouze obecný popis podlahového sendviče. Z prvků, které tvoří strukturu, lze vyčíst často množství dalších informací týkajících se například typu použitého materiálu, doby vzniku nášlapu, prostředí, ve kterém vznikal, nebo způsobu, jakým byl povrch př́padně udržován.

Na základě studia podlahových horizontů suterénů a nadzemních staveb na území Brna datovaných do konce 13. a začátku 14. století jsme se pokusili rekonstruovat typy konstrukcí podlahových sendvičů v závislosti na pozici v rámci domu nebo parcely, způsoby jejich využívání, a v neposlední řadě také varianty péče o tyto pochozí horizonty. Hlavními otázkami kladenými při interpretaci podlahových sendvičů byly možné paralely či rozdíly mezi nadzemními stavbami a suterény, detekce intenzity využití prostoru, způsob využití prostoru, podmínky panující v daném prostoru, ale také typy materiálu použité při konstrukci podlahových sendvičů. V neposlední řadě nás samozřejmě zajímala také informace o tom, jak se liší makroskopické terénní pozorování a s ním související interpretace od mikromorfologického výstupu. Diskutována je také otázka možných paralel tvorby a úpravy podlahových setů ve středověku a v nedávné minulosti.

\section{Studovaný materiál}

První vzorky na mikromorfologickou analýzu z kontextu stř̌edověké zástavby byly na brněnských výzkumech odebrány v roce 2008 , ve zvýšené míře a systematicky pak v posledních pěti letech. Odebírání samotných vzorků bylo časově velmi náročnou záležitostí, která často probíhala v obtížných terénních podmínkách záchranných výzkumů v různých ročních obdobích. Mnoho vzorků se nepodařilo odebrat na první pokus, a celý proces musel být $\mathrm{v}$ rámci některých lokalit či jednotlivých objektů často opakován. Za rozhodnutím dlouhodobě sledovat tento výzkumný cíl v našich zemích byl tým archeologů z nestátního ústavu Archaia Brno spolu s L. Lisou z Geologického ústavu AV ČR. Získaná kolekce z prostoru středověkého Brna již čítá přes 200 exemplářů (cca 25 ve formě výbrusů), z nichž většina je vázána na situace související s nezděnou středověkou zástavbou Brna a jeho historických předměstí. Je to nepochybně největší soubor vzorků svého druhu v ČR, a patrně v rámci celé stř̌ední Evropy. Doposud byly vyhodnoceny a publikovány pouze výsledky analýz vzorků z podlahových vrstev nadzemních částí čtyř staveb zkoumaných v roce 2015 při archeologickém výzkumu na parcele č. 601 při Veselé ulici (Lisá et al. 2020b). Kromě nich došlo ještě ke zveřejnění poznatků získaných ze vzorku odebraného ze dna středověké zásobní jámy zkoumané v roce 2008 na nádvoří domu Bašty 2 (Lisá et al. 2017). Množství zpracovaných mikromorfologických vzorků je publikováno formou neveřejných výzkumných zpráv.

Vzorky, které jsou prezentovány a diskutovány v této práci, byly získány při záchranných archeologických výzkumech realizovaných ústavem Archaia Brno v průběhu let 2008 až 2015. Pochází z celkem pěti různých poloh středověkého města v hradbách, včetně již částečně publikované lokality Veselá (obr. 1). Vnitřní město bylo nejméně od 14. století rozděleno na čtyři čtvrti (viz Vičar 1965). Zkoumané parcely na ulicích Bašty a Biskupská byly součástí někdejší čtvrti Brněnská v jihozápadní 


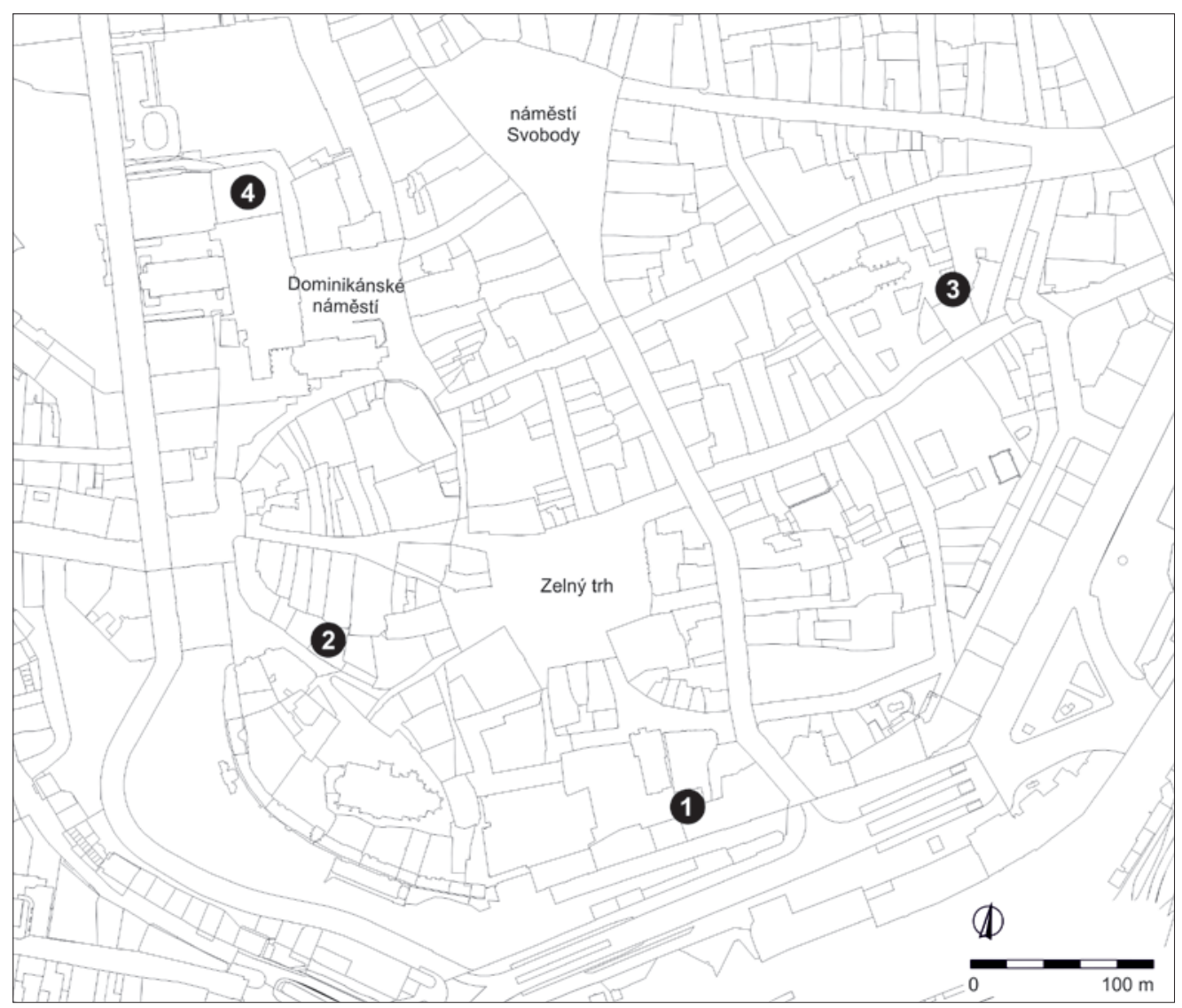

Obr. 1. Vyznačení polohy př́slušných archeologických výzkumů ve výřezu katastrální mapy Brna. 1 - Bašty; 2 - Biskupská; 3 - Orlí; 4 - Panenská Autor M. Peška.

Fig. 1. Location of the archaeological excavations in the cadastre map of Brno. 1 - Bašty street; 2 - Biskupská street; 3 - Orlí street; 4 - Panenská street. Author M. Peška. části města, Orlí náležela do čtvrti Měnínská v jihovýchodní části města a ulice Veselá a Panenská se nacházely ve Veselé čtvrti v severozápadní části města (obr. 2).

Jak již bylo zmíněno, odběr mikromorfologických vzorků neprobíhal náhodně, ale vždy s konkrétním cílem a z relativně dobře rozlišených archeologických situací. Tři vzorky byly odebrány vertikálně $\mathrm{v}$ suterénu dřevohliněné stavby na parcele č. 165/1 domu Orlí 19. Další čtyři pocházejí z výzkumu na parcele č. 351 domu Bašty 2-4, kde byla horizontálně vzorkována podlahová úroveň suterénu dřevohliněné stavby a zahloubené části stavby, jejíž hloubka však nebyla tak výrazná. Pět vzorků bylo odebráno v průběhu výzkumu parcely č. 381 domu Biskupská 7. Jeden zahrnul podlahovou úroveň suterénu a zbývající sledovaly vrstvy nadzemních partií čtyř staveb. Poslední set čtyř vzorků pochází ze tří suterénů a jednoho segmentu nadzemní partie domu na parcele č. 501/1 na ulici Panenská 1. Tyto vzorky byly rozměrnější, aby vždy pokrývaly celou výšku setu podlahového sendviče, proto byly pro účely analýzy roděleny do celkem devíti výbrusů, které na sebe ve skupinách po dvou či po třech vertikálně navazují.

V př́padě vzorků z Orlí 19 byla od mikromorfologické analýzy očekávána odpověd’ nebo alespoň indicie pro řešení otázky, zda je možné v průběhu existence suterénu vyčlenit dvě fáze (blí̌ze viz popis nálezové situace). Vzorky z ulice Bašty 2-4 nabízejí možnost porovnat projev dvou typově odlišných zahloubených objektů, přičemž jeden objekt zde zastupuje měštanskou architekturu vrcholně středověkého města a druhý lze pravděpodobně spojit ještě s předlokačním osídlením. Vzorky z Biskupské 7 umožňují srovnání projevu podlahových úrovní nadzemních staveb ze dvou původních městišt’, přičemž relikty dvou staveb se nacházely ve vztahu stratigrafické posloupnosti. Vzorky z Panenské 1 měly za cíl zpřesnit informaci o typu materiálu použitého jako pochozí horizont a způsob formování podlahového sendviče.
Získaná data byla následně konfrontována s již publikovanými výsledky ze studia podlahových vrstev čtyř staveb z Veselé ulice. Výběr vzorků byl zvolen také pro možnou komparaci suterénů a nadzemních partií, v př́padě Biskupské $7 \mathrm{v}$ rámci jedné lokality. V textu studie tedy jsou konfrontovány výsledky analýz 24 vzorků z pěti lokalit, resp. z 11 staveb z různých částí historického jádra Brna, přesněji ze sedmi suterénů, sedmi nadzemních partií dřevohliněných staveb a jednoho nepř́liš̌ výrazně zahloubeného objektu z počátků města. Všechny vybrané relikty nezděné zástavby pocházejí z období 13.-14. století.

\section{Exkurs: nezděná zástavba středověkého Brna}

Relikty nezděné zástavby sředověkého Brna byly při archeologických výzkumech dokumentovány již od 80. let 20. století a postupně docházelo k souhrnným vyhodnocením získaných poznatků (Loskotová, Procházka 1995; Procházka 1996, 120-128; Procházka 2000, 107-113). Koncem 90. let byla její problematika vytyčena jako jeden ze základních okruhů badatelského zájmu nově založené společnosti Archaia Brno a nezděná zástavba se stala předmětem systematického výzkumu, který zajištuje kolektiv odborných pracovníků této instituce. První souhrnné zpracování věnované tomuto tématu představuje studie z roku 2005 (Holub et al. 2005); aktualizace a shrnutí nových poznatků bude součástí publikačních výstupů grantového projektu „Proměna městského domu ve 13. století“ (GAČR reg. č. 17-23836S).

Brněnská měštanská zástavba byla, stejně jako v ostatních českých a moravských městech, do 14. století převážně nezděná. Na její konstrukci bylo používáno zejména dřevo a jako doplňkový materiál hlína (především ve formě mazanice). Zděné stavby se sice vyskytují již od založení města, jejich četnost se však postupně zvyšuje až v 2. polovině 13. století či spíše na jejím konci. Jistý stavební rozmach předpokládáme kolem roku 1300 a k nahrazení většiny dřevohliněné zástavby došlo zřejmě v masovém 


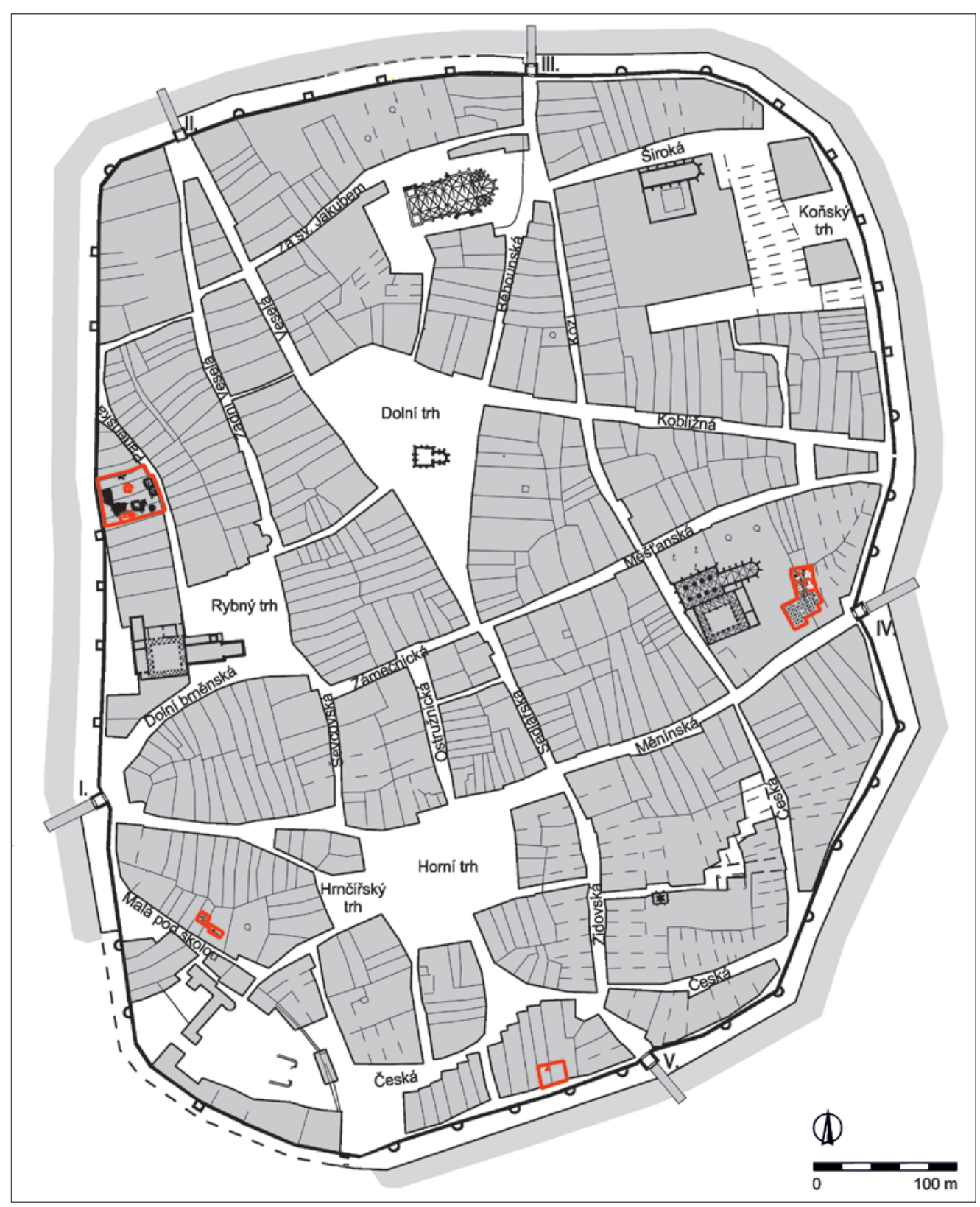

Obr. 2. Vyznačení polohy archeologických výzkumů do rekonstrukčního plánu k roku 1348. Podle Vičar 1965.

Fig. 2. Location of the archaeological excavations in the reconstruction plan from 1348. According to Vičar 1965. měřítku během 1. poloviny 14. století. $\mathrm{V}$ předhusitském období již Brnu dominovaly stavby se zděným jádrem. Dřevohliněné konstrukce však zcela nevymizely, což dokládají jednak archeologické výzkumy, ale i ikonografie a stavebněhistorické průzkumy.

K uvedeným závěrům opravňují především výsledky archeologických výzkumů (Holub et al. 2005; 2013a; 2015, 315-323) a stavebněhistorických průzkumů dochovaných torz středověkých zděných domů. Ikonografické prameny pro toto období nejsou k dispozici, větší objem písemných pramenů přichází až s polovinou 14. století. Poskytují sice nepříliš četné a většinou kusé, avšak v několika př́ípadech také zajímavé zprávy o stavební podobě brněnských domů. Jejich výpověd’ $\mathrm{k}$ tomuto tématu se pokusil shrnout Vičar ve své práci z roku 1971 (Vičar 1971), dílčí poznatky jsou nejnověji prezentovány v rámci publikace $\mathrm{z}$ roku 2013 (Holub et al. 2013b, 823-825), pozornost historiků se však tímto směrem dosud výrazněji neupřela. Ovšem zřejmě i po vytěžení veškerého potenciálu archivních pramenů bude i nadále mít v této problematice rozhodující slovo archeologické bádání.

Někdejší nezděné stavby dnes reprezentují většinou jejich zahloubené části odkrývané v průběhu posledních čtyř desetiletí archeologickými výzkumy. Vedle ojedinělých malých kopaných sklípků a ražených sklepů jsou to především nezděné suterény jako nejvýraznější a nejčastější doklad dřevohliněné zástavby středověkého Brna. Potkáváme se s nimi při archeologických výzkumech takřka na všech někdejších městištích ve vnitřním městě (souhrnně včetně katalogu naposledy Holub et al. 2005), a jsou registrovány také při výzkumech historických předměstí, která tvořila průběžný pás osídlení kolem městských hradeb (Černá et al. 2012, 107; 2014, 182; Holub et al. 2006, 184, 202; 2008, 363; Procházka et al. 2013). Archeologické akce potvrzují jejich existenci také v osadách tvořících širší sídelní strukturu v okolí města (např. někdejší ves Královo Pole - Holub et al. 2006, 205; 2007, 438, 439; osada na pravobřeží Starého Brna Zůbek 2018, 81-86; Zapletalová, Hložek 2010, 137-140). Nicméně vedle zahloubených částí někdejších domů byla v areálu středověkého Brna sporadicky dokumentována i torza souvrství nášlapů a podlah či nejrůznější sloupové jamky a žlábky, které jsou naopak nepř́mými doklady nadzemních částí dřevohliněných staveb.

Zahloubené prostory většinou obdélných či čtvercových půdorysů sloužily jako sklepy domů či hospodářských budov. Jejich stěny byly zpevněny dřevěnými konstrukcemi, př́ístupné byly 
předsazeným vstupním schodištěm či vstupní šijí. Umístění suterénů na parcelách bývá rozmanité. Stále nemáme přesvědčivé doklady o jejich nadzemních částech, předpokládáme však, že obytné domy byly situovány spíše blíže uliční čáře, a zejména sklípky a stavby menších rozměrů ve dvorních partiích mohly mít pravděpodobně hospodářský účel, a to i v př́ípadě, že se jednalo o oddělené části domů. Určitou roli v tomto př́padě hraje i otázka patrovosti jednotlivých staveb. V případě menších staveb (napr. typu špýcharů) mohl být tedy podsklepen celý prostor. U suterénů, které jsou vázány na přední část parcely, lze předpokládat, že náležely $\mathrm{k}$ př́ślušným domům, které stály $\mathrm{v}$ jejich čele. Rozsah těchto suterénů je rozličný, v Brně byly dosud dokumentovány př́pady v rozmezí 16 až $157,5 \mathrm{~m}^{2}$. Některé $\mathrm{z}$ nich byly členěny prostřednictvím příček na dílčí prostory. $\mathrm{V}$ př́ípadě suterénů menších velikostí předpokládáme, že jimi byla podsklepena pouze část př́slušného domu. U některých rozsáhlejších objektů je možné, že zabíraly téměř celý půdorys domu (např. suterén s.s.j. 002 z náměstí Svobody 17 o výměře $120 \mathrm{~m}^{2}$ - Holub et al. 2005, 89-90). Právě mikromorfologická analýza podlah dřevohliněných staveb by nám mohla v budoucnu pomoci nalézt rozdíly mezi jednotlivými stavbami na parcele a případně upřesnit jejich využití.

Poznatky k nadzemním partiím staveb jsou doposud minimální. Jejich poznání je komplikováno, a často v podstatě znemožněno, velkou mírou poničení stř̀edověkého terénu. Zmíněná povrchová souvrství na řadě míst chybí. Výsadní postavení si v tomto ohledu drží severozápadní a jihovýchodní část městského jádra, kde došlo v průběhu středověku k postupnému nárůstu terénu až o $2 \mathrm{~m}$, a na poměrně velkých plochách zůstalo souvrství zachováno do dnešních dnů. V jihovýchodní partii jde o lokality při Františkánské a Josefské ulici. Velká část archeologických akcí se zde však uskutečnila v počátečním období systematického výzkumu Brna a z dnešního pohledu nevytěžila dostatečným způsobem informace týkající se nadzemních částí staveb (Holub et al. 2005, 45, 55; Procházka 2000, 52-60; Procházka, Zůbek 2012 aj.). Př́ślibem do budoucna mohou být nové výzkumy, které budou prováděny při chystaných investičních a revitalizačních akcích $\mathrm{v}$ tomto prostoru. V severozápadní části města jde především o oblast kolem ulice Besední a Veselé. $\mathrm{Z}$ dalších menších lokalit $\mathrm{v}$ jádru města lze zmínit např́íklad Biskupskou ulici, dílčí poznatky k nadzemním partiím zástavby zde byly získány na parcele domu č. 7 (Borský et al. 2016, 215-218). Ve většině případů zůstaly po nadzemních stavbách zachovány často jen solitérní sloupové a kůlové jamky. Méně časté jsou relikty podlahových úprav, tvořené většinou hliněnými vrstvičkami s pozorovatelnými „nášlapy“. Ucelené půdorysy a přesné konstrukční řešení staveb většinou neznáme, několik prrípadů však bylo dokumentováno např. pří záchranném výzkumu na ulici Veselá v letech 2015 až 2017, který je v současnosti ve fázi zpracování. Z prostoru brněnských historických předměstí nabízí podle dosavadních poznatků velký potenciál především území první předměstské čtvrti v oblasti jihovýchodně od hlavního vlakového nádraží. Zachovány jsou zde mohutná stř̌edověká souvrství včetně reliktů nadzemních staveb zahrnující především podlahová souvrství (dosavadní vyhodnocení Zůbek 2019), z nových výzkumů lze jmenovat odkryv na Římském náměstí za domem Orlí 14. Př́slibem do budoucna je dosud nevyhodnocený záchranný archeologický výzkum společnosti Archaia Brno v místech někdejšího hotelu Metropol při křižovatce ulic Mlýnské a Dornychu, kde bylo také zachyceno několik nadzemních staveb; stejně jako v př́ípadě Veselé ulice je výzkum ve fázi zpracování. U všech nadzemních objektů v rámci zmíněných lokalit byly odebrány vzorky podlahových setů pro budoucí analýzy.

\section{Metodický přístup studia podlahových horizontů}

Metodický prrístup studia podlahových horizontů má svá časová a prostorová úskalí. Vzhledem k tomu, že prezentované vzorky byly odebírány během časového úseku cca 10 let a že jde o metodiku v posledních letech výrazně inovovanou, pokusili jsme se během té doby dojít ke konsensu z jakých situací a v jakém množství vzorky odebírat, abychom dostali dostatečné množství informací za přijatelnou cenu a energii do odběrů a zpracování vloženou. Způsob, jakým jsou odebírány podlahové sendviče, není limitován pouze finanční náročností, ale především interpretační možností archeologického kontextu. Nejvhodnější situace pro odběr, resp. následující interpretaci, jsou velkoplošné výzkumy, kde je zřejmý prostorový vztah nejen k umístění na parcele, ale také k vazbám na další budovy nebo využití otevřeného prostoru. Ideální je situace, kdy lze interpretovat typ stavby a prostorový vztah k okolí na základě archeologických indicií, což může být nap̌r. umístění suterénu v přední části parcely, či při jiné komunikaci v rámci domovního bloku, dále je to př́tomnost topeniště či nálezy keramických a jiných skladovacích nádob na podlaze. Vlastní mikromorfologická analýza následně pouze precizuje informaci o způsobu využití v konkrétním kontextu.

V př́ípadě suterénů je vzorkování náročnější, protože jsou většinou tvořeny opakovaným setem mikrovrstev prokládaných sanitárními vrstvami. Pro pochopení dané situace je tedy nutné vzorkovat větší množství vzorků vertikálně. V případě nadzemních podlahových sendvičů, které nejsou př́liš mocné, je problém opačný. Mocnost podlahového sendviče je poměrně malá, ale prostorově variabilní. V takovém prŕípadě je vhodné odebírat větší množství vzorků v horizontálním směru, a to tak, aby vzorek vždy zachycoval podlahový sendvič a jeho podloží, pokud to situace dovoluje. Ve všech př́padech je nutné odebírat plošně větší vzorky, tj. nejméně $4 \times 7 \mathrm{~cm}$, případně větší.

Při odběru je nutné dodržet několik základních kroků. V první řadě musí být alespoň rámcově zřejmé, z jakého kontextu je vzorek odebírán, resp. jeho předpokládaná interpretace např. suterén; nadzemní prostor objektu; typ objektu - obytný, výrobní, ustájení; koridor; venkovní plocha, zásyp. Vzorky jsou následně vyříznuty z profilu, a to tak, aby pokrývaly ideálně celý podlahový sendvič i s podložím. Plocha odběru se tedy bude různit, neměla by však u jednoho vzorku přesáhnout $30 \mathrm{~cm}$, a to $\mathrm{z}$ důvodu problémů spojených s následným zpracováním. Pokud je nutné odebrat mocnější souvrství, je nutné odebrat vzorky vždy s přesahem alespoň $2 \mathrm{~cm}$, tak aby mohly být informace na sebe navázány. Vzorky mohou být odebírány do papírových, plastových nebo plechových boxů či do sádrových obvazů a následně fixovány do potravinářské fólie. Důležité je, aby se při odběru nerozpadly, aby byly zafixovány ve folii a nevyschly dříve, než budou transportovány do laboratoře spolu s předávacím protokolem. Na vzorcích musí být jednoznačně označen jejich původ v souladu s nezaměnitelným číslováním jednotlivých stratigrafických jednotek archeologického výzkumu a šipka ukazující směrem vzhůru do nadloží. Pokud to situace dovoluje, je vhodné odebírat krychle nebo kvádry o rozměrech $4 \times 7 \times 4 \mathrm{~cm}$, případně delší. Množství odebraného materiálu může být následně využito pro další analýzy (geochemickou analýzu, analýzu magnetické susceptibility, pylovou nebo fytolitovou analýzu).

Po transportu do laboratoře byly všechny odebrané vzorky vysušeny a naimpregnovány ve vakuu pryskyřicí Polylite 2000. Po vytvrdnutí, které trvá většinou 6 týdnů, byly vzorky rozřezány a zpracovány do formy krytých výbrusů. Č́st vzorků byla zpracovávána v laboratoři Geologického ústavu AV ČR, v. v. i., část na univerzitě v Gentu nebo na univerzitě v Cambridge. Velikost prezentovaných vzorků se pohybuje většinou ve velikosti $4 \times 7 \mathrm{~cm}$ 
nebo $9 \times 5 \mathrm{~cm}$, v př́ípadě např́íklad lokality Panenská, kde byly vzorkovány mocnější podlahové sendviče suterénů, je velikost odebraných vzorků $5 \times 22$ nebo $5 \times 18 \mathrm{~cm}$. Výsledná plocha pro studium je ve finále tvořena dvěma až třemi na sebe navazujícími výbrusy. Vzorky ve formě výbrusů byly studovány pod binokulárním mikroskopem (Olympus) při zvětšení 4-8× a následně v polarizačním mikroskopu (Nikon) při zvětšení 16-400×. Ve vzorku byly popisovány jednotlivé subfacie, které podlahový sendvič vytvářejí. U nich je následně sledována především mikrostruktura, způsob vytř́ídění, typy a četnost jednotlivých pórů, minerální složení hrubé a jemné frakce, typy organické a organominerální složky a pedogenní struktury dokumentující postsedimentární změny v sedimentu. Vzorky byly popisovány primárně podle metodiky G. Stoopse (2003) a interpretovány na základě dostupné literatury. Výsledky a interpretace jsou v textové části s odkazy na obrazovou dokumentaci a detailními popisy v tab. 1 (viz níže).

\section{Výsledky a interpretace}

\subsection{Historický kontext a nálezová situace vzorků z lokality Bašty 2-4, parcela č. 351 (obr. 20: 1, 2 - viz níže)}

Zkoumaná parcela náležející $\mathrm{k}$ domu Bašty 2-4 (č. p. 413) se nachází v jižní části města. Ve středověku byla součástí domovního bloku v těstné blízkosti městské hradby a Židovské brány. Blok tvořilo několik městišť s průčelím do Uhelného trhu (forum Carbonum, dnes Kapucínské náměstí, a do uličky Před židovskou hradbou (Prope portam Judeorum, dnes dolní část Masarykovy ulice). Prostor byl osídlen již před založením města ve 12. století. Archeologický výzkum byl realizován v roce 2008 v souvislosti s výstavbou parkovacího domu pro plánovaný hotel Padowetz (Dejmal, Peška 2010; Holub et al. 2010, 403-404). Odkryta byla plocha ve dvorní části domu, která podle historických rekonstrukcí náležela zadní části městišť orientovaných k Uhelnému trhu. Výzkum dokumentoval vývoj prostoru od předlokačního osídlení přes vznik města až do současnosti. Nezděnou architekturu reprezentovaly dva zahloubené objekty, jeden ještě z předlokačního období nebo samotných počátků města (s.s.j. 057), ${ }^{1}$ druhý již, dle keramického materiálu z přelomu 13. a 14. století ze zásypu sloupových jam a vzhledem k respektování parcelních hranic, souvisel s městskou strukturou zástavby (s.s.j. 059). Stratigrafie, resp. souvrství nad geologickým sprašovým podložím, byla zcela zničena, takže nelze vysledovat, zda zde v průběhu středověku nestály i nadzemní dřevohliněné stavby.

\subsubsection{Vzorek A20/1 a A20/2 ze s.s.j. 057 - zahloubená část stavby}

Podlahové sendviče byly uloženy na plochém dně výkopu a makroskopicky je bylo možné rozlišit na dvě uloženiny. Spodní byla tvořena tmavě šedou jílovitou hlínou s malým množstvím uhlíků a drobnými zlomky žluté písčité hlíny (s.j. 234), horní sestávala ze světle šedé jílovité hlíny s nahodilými uhlíky a četnými malými zlomky žluté jílovité hlíny (s.j. 233). Původní rozměry objektu byly větší než $3,1 \times 2,3 \mathrm{~m}$, hloubka od předpokládaného původního povrchu činila $0,85 \mathrm{~m}$. Ve zkoumaném segmentu byly dokumentovány tři sloupové jamky, do nichž byly patrně zapuštěny sloupy nadzemní konstrukce. K objektu lze přiřadit ještě další jamku v severním sousedství; dvě jamky při jižní hranici mohly souviset se vstupem do stavby. Zda byla zahloubena jen její část nebo celý půdorys, se nepodařilo ověřit. Ze zásypu objektu po zániku jeho funkce byly získány fragmenty keramiky datované do 1. poloviny 13. století. Vzorky byly odebrány ve vertikálním směru z podlahových úrovní zahloubené části stavby cca 2 metry od sebe.

Vzorek A20/1 bylo možné rozčlenit z pohledu mikromorfologie na dvě základní facie, a to A a B (obr. 3). Detailní mikromorfologický popis je v tab. 1 .

Vzorek A20/2 bylo možné rozčlenit z pohledu mikromorfologie na celkem 4 základní facie, a to A, B, C a D (obr. 4). Detailní mikromorfologické popisy studovaných vzorků jsou uvedeny v tab. 1. Interpretace vzorků A20/1 a A20/2 je následující: pocházely z jedné úrovně jednoho objektu. Protože šlo o poměrně málo mocný podlahový sendvič odkrytý v celé délce zastavěné plochy, byl zde prostor pro odebrání více než jednoho vzorku, což se ukázalo jako prozřetelné. Přestože podlahová vrstva
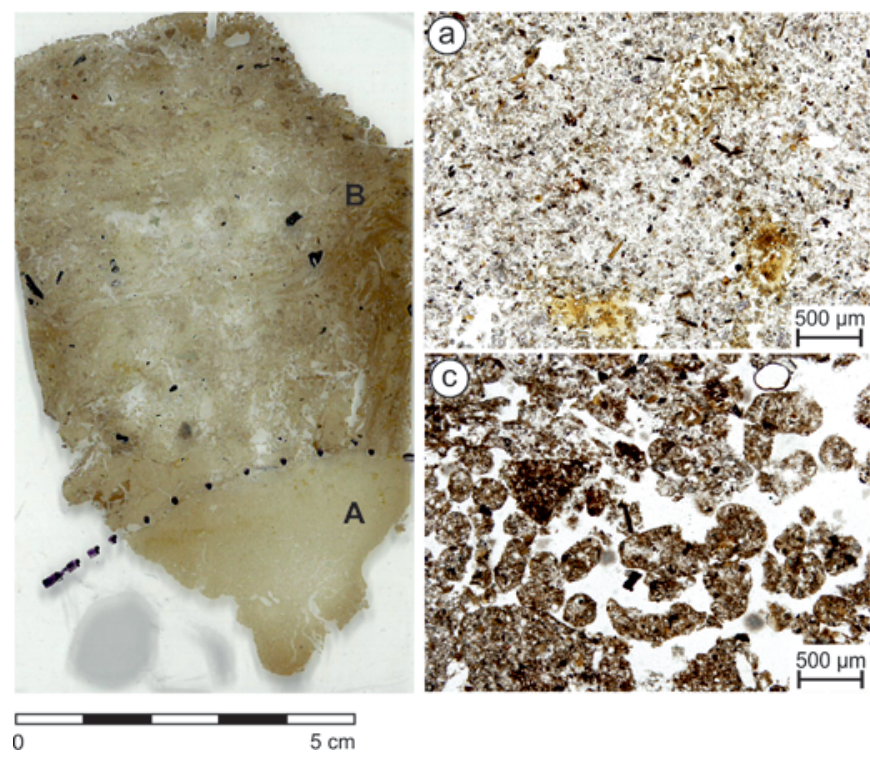

Obr. 3. Základní mikrostratigrafické členění podlahového setu vzorku A20/1 z lokality Bašty s př́kladem typické mikrostruktury; a - místy je matrix impregnována prosakujícími fosfáty (subfacie A); b - uhlíky (žlutá šipka); mikrouhlíky (červená šipka); artikulované fytolity (zelená šipka); fragmenty propálených kostí (modrá šipka) (subfacie B); c - exkrementy mikrofauny (přechod mezi subfacií A a B); d - impregnace matrix fosfáty a železem (subfacie B). Všechny mikrofotografie jsou foceny v průchozím světle (PPL). Autor L. Lisá.

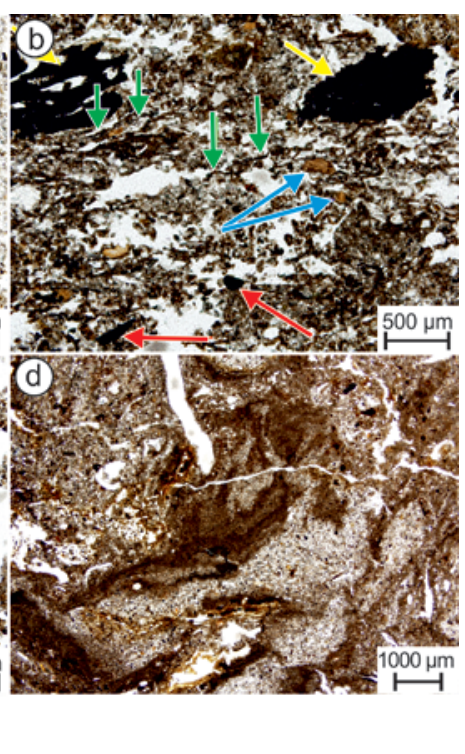

Fig. 3. Basic microstratigraphical division of the floor set documented in sample A20/1 from the Bašty site with examples of the most common micromorphological features; a - the matrix is in places impregnated by percolating phosphates (subfacie A); $b$ - charcoal (yellow arrow); microcharcoal (red arrow); articulated phytoliths (green arrow); fragments of burned bones (blue arrow) (subfacie B); $C$ - microfauna excrements (the transition between subfacie $A$ and $B$ ); $d$ - the $\mathrm{Fe}$ and $P$ impregnation of the matrix (subfacie $B$ ). All microphotographs were taken in plane polarised light (PPL). Author L. Lisá. 

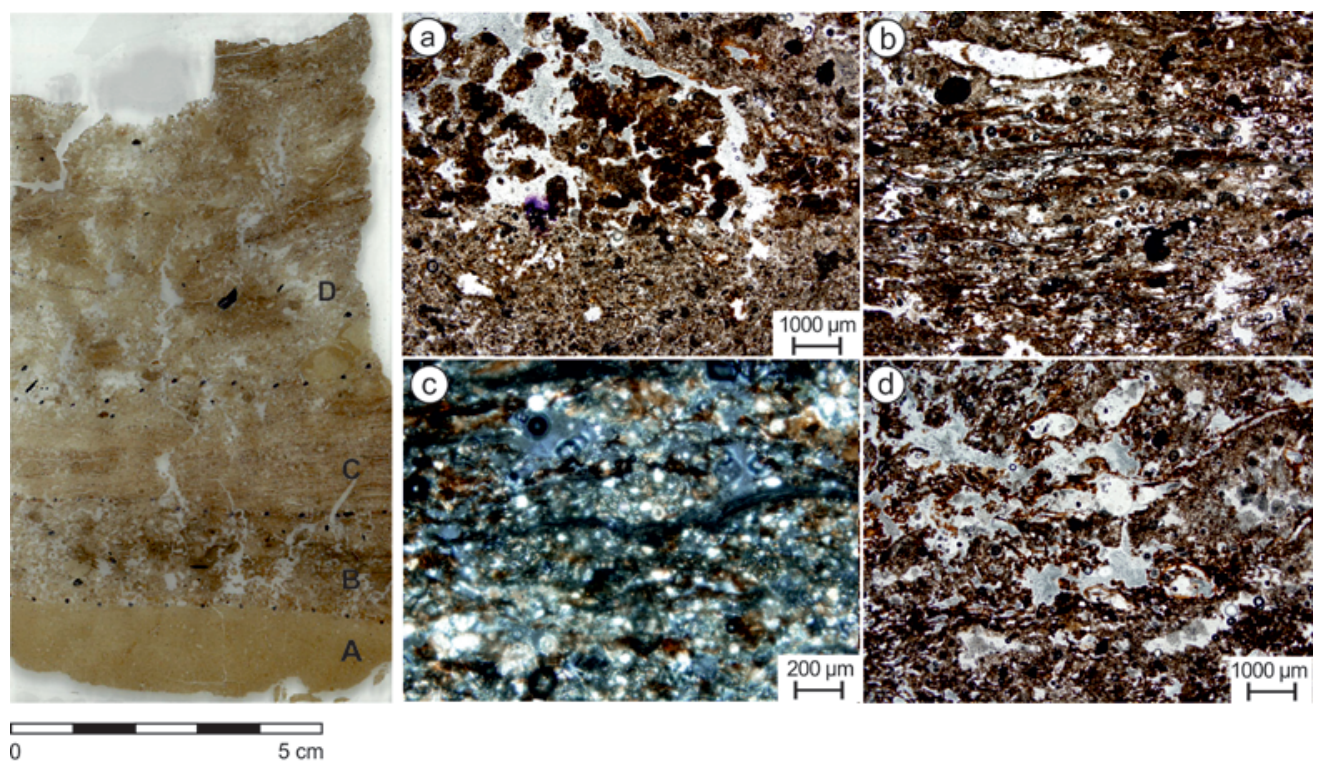

Obr. 4. Základní mikrostratigrafické členění podlahového setu vzorku A20/2 z lokality Bašty s príkladem typické mikrostrury; a - přechod mezi subfacií A a B. Ve svrchní části je akumulace exkrementálních struktur po činosti mikrofauny; b - horizontálně akumulované artikulované fytolity se zbytky rozložené organické hmoty (subfacie C); c - detail na horizontálně uložené akumulace fytolitů. Minerální frakce je tvořena převážně mikritickým a sparitickým karbonátem (subfacie C); $\mathrm{d}$ - nehomogenní bioturbovaná matrix bohatá na organickou hmotu, místy jsou zřetelné akumulace víceméně horizontálně uložených artikulovaných fytolitů (subfacie D). Mikrofotografie a, b, d jsou pořízeny v procházejícím světle (PPL), mikrofotografie c je pořízena ve světle procházejícím zkř́íženými nikoly (XPL). Autor L. Lisá.

vykazovala horizontálně stejné vlastnosti, z hlediska primárního výskytu a také zachování jednotlivých facií jsou studované vzorky poměrně odlišné. Zatímco ve vzorku A20/1 je v mocnosti cca $7 \mathrm{~cm}$ zachována pouze silně bioturbovaná matrix, pravděpodobně stejný typ matrix, ovšem rozčleněný do několika horizontů, je zachován ve vzorku A20/2 v odlehlé části objektu. Podlahová úroveň objektu je tvořena pasivní vrstvou reprezentovanou spraší, na niž nasedá agradovaná pochozí vrstva tvořená množstvím organické hmoty. Ta je zachována především ve formě artikulovaných, horizontálně uložených fytolitů, což indikuje akumulaci sena nebo slámy na pochozí plochu. Tyto jsou zároveň prosyceny minerální matrix, což indikuje postupnou, opakovanou akumulaci podlahové vrstvy bez nutnosti čištění nebo odstraňování formou zametání. Minerální frakce je v tomto případě nabohacena na mikritický a sparitický karbonát který může pocházet jak ze spraše, tak ovšem i z př́ípadného popela, čemuž by nasvědčovala občasná př́tomnost mikrouhlíků nebo fragmentů spálených kostí. Podlahová pochozí úroveň je extrémně bohatá nejen na organickou hmotu ve formě rozprostřeného sena nebo slámy, ale obsahuje zároveň občasné zbytky z běžného odpadu (uhlíky, spálené kosti). Celý set je silně bioturbovaný, extrémně v případě vzorku A20/1, kde byla stratigrafie navíc silně porušena prosakující vodou, která redeponovala fosfáty a železo do podloží. V př́ípadě vzorku A20/2 je podlahový set lépe zachován a postižen především bioturbací. Intenzivní bioturbace je spojena s přítomností rozkládající se organické hmoty. Výsledkem je akumulace exkrementů mikrofauny, která je velmi dobře zřetelná na přechodu mezi podložím a akumulovanou podlahovou vrstvou, a dále potom ve svrchní části akumulované vrstvy. Otázkou zůstává způsob využití sledovaného prostoru. Jedna z možností, která je spojená s větším množstvím rozkládající se organické hmoty, může být spojována s podestýlkou zvířat. Exkrementy ve formě fekálních sferulitů
Fig. 4. Basic microstratigraphical division of the floor set documented in sample A20/2 from the Bašty site with examples of the most common micromorphological features; $a$ - the transition between subfacie $A$ and $B$, in the upper part of the photo there is the accumulation of excremental features after microfauna visible; $b$ - horizontally accumulated articulated phytoliths with the remnants of decomposed organic matter (subfacie C); c - horizontally oriented accumulations of phytoliths - detail; the mineral fraction is composed mostly of micritic and sparitic carbonate (subfacie $C$ ); $d$ - unsorted and bioturbated matrix rich of organic matter; the accumulations of horizontally accumulated and articulated phytoliths are visible in some places (subfacie D). The microphotographs $a, b$ and $d$ were taken in plane polarised light (PPL), microphotograph c was taken in cross polarised light (XPL). Author L. Lisá.

nebo natrávených kostí zde však nebyly indikovány ve výrazném množství, stejně tak ani přítomnost parazitů. Z makroskopického pozorování v terénu se v tomto př́padě nejednalo o typicky nášlapové ani o konstrukční vrstvy.

\subsubsection{Vzorek A20/4 a A20/5 ze s.s.j. 059 - suterén}

Vzorky byly odebrány z podlahových úrovní zahloubeného objektu, které byly uloženy na jeho plochém dně, a to v horizontálním směru vždy cca 2 metry od sebe. Na jednom ze vzorků je zřetelný úklon a jedná se pravděpodobně o vchodový koridor. Objekt byl interpretován jako suterén dřevohliněné stavby. Vybaven byl sklípkem vyhloubeným do východní stěny při jihovýchodním rohu. Suterén byl bezprostředně nahrazen středověkým zděným sklepem, který ve funkci ponechal i zmíněný sklípek. Suterén měl rozměry cca $4 \times>2 \mathrm{~m}$, dokumentovaná hloubka činila 1,30 m. Dle vyhodnocení stratigrafické situace ho lze datovat do 13. století. Není vyloučeno, že vznik podlahové úrovně souvisí až se zděným nástupcem suterénu.

Vzorek A20/4 bylo možné z hlediska mikromorfologie rozčlenit na tř̀i samostatné subfacie s ostrými přechody. Jsou označeny zdola nahoru jako A, B a C (obr. 5). Vzorek A20/5 bylo možné z hlediska mikromorfologie rozčlenit na dvě samostatné subfacie s ostrými přechody. Jsou označeny zdola nahoru jako A a B (obr. 6). Detailní mikromorfologické popisy studovaných vzorků jsou uvedeny v tab. 1. Interpretace vzorků A20/4 a A20/5 je následující: vzorky reprezentují průběžný podlahový sendvič, který je na bázi tvořen spraší. Samotný pochozí horizont vznikl opakovanou agradací materiálu, který se mohl přenášet např. obuví. Tento materiál je tvořen především odpadem $z$ otopného zařízení, které bylo detekováno v těsné blízkosti objektu. Sklon jednotlivých mikrovstviček u vzorku A20/5 indikuje vchodovou část. Tento typ pochozího horizontu vznikl necílenou akumulací a nenese známky konkrétního typu úpravy. 

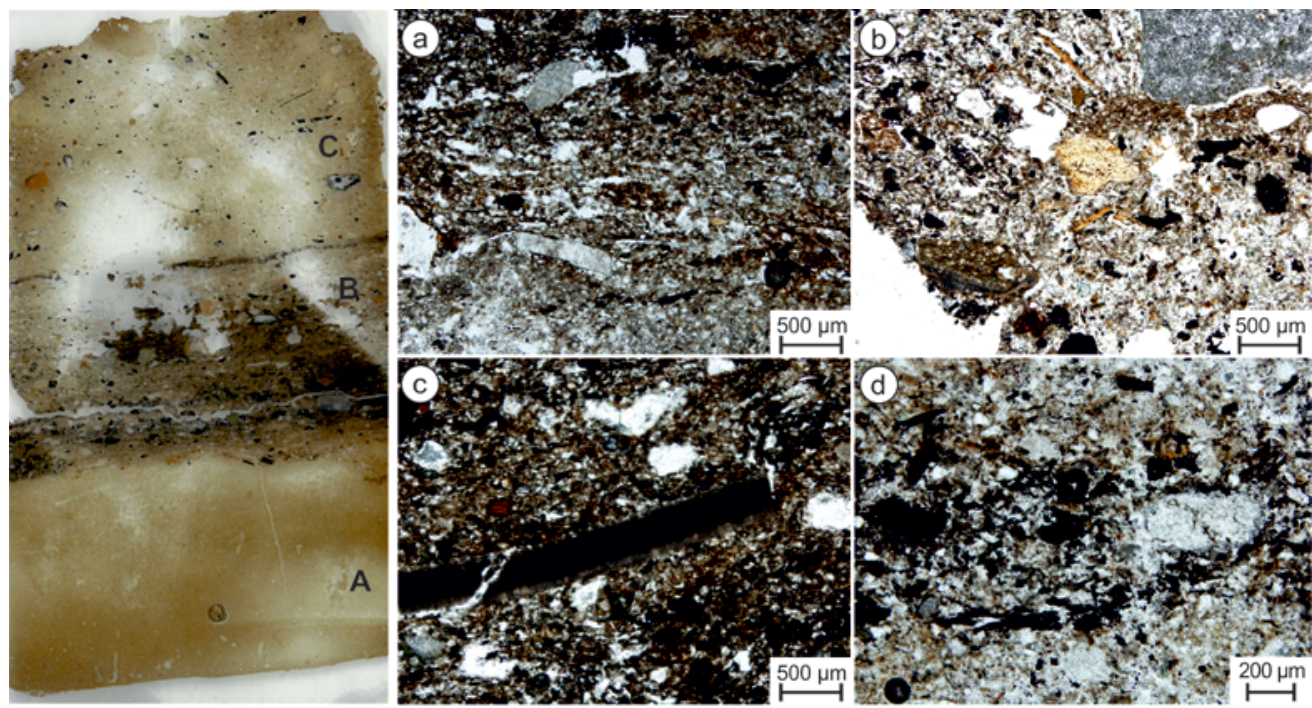

0

$5 \mathrm{~cm}$

Obr. 5. Základní mikrostratigrafické členění podlahového setu vzorku A20/3

z lokality Bašty s př́íkladem typické mikrostruktury; a - horizontálně uložené uhlíky a mikrouhlíky spolu s orientovanou minerální matrix, přechod do podloží je ostrý; b - v centru tři fragmenty propálené kosti; c - skořápka vajíčka; d - mikrouhlíky v rámci facie $B$ tvoří ve svrchní části tenkou vrstvičku. Všechny prezentované mikrofotografie pocházejí ze subfacie $B$ a byly pořízeny v procházejícím světle (PPL). Autor L. Lisá.
Fig. 5. Basic microstratigraphical division of the floor set documented in sample A20/3 from the Bašty site with examples of the most common micromorphological features; a - horizontally accumulated charcoal and microcharcoal together with an oriented matrix, the transition into the layer below is sharp; $b$ - three fragments of burned bones in the centre; c - egg shell; $d$ - upper part of the subfacie $B$ is

characteristic for the thin layer of microcharcoal. All presented microphotographs come from subfacie $B$ and were taken in plane polarised light (PPL). Author L. Lisá

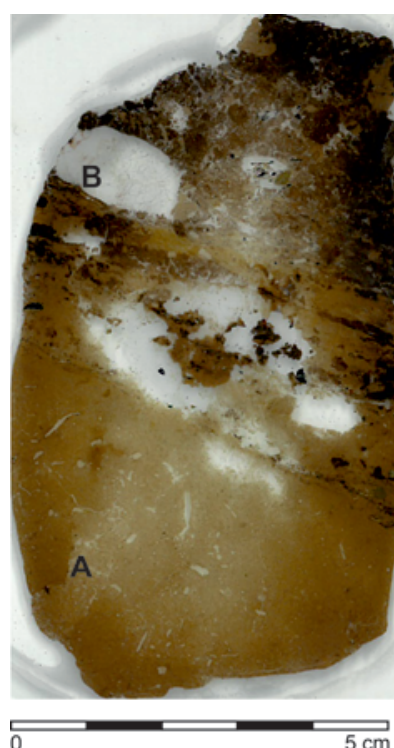

Obr. 6. Základní mikrostratigrafické členění podlahového setu vzorku A20/4 z lokality Bašty s př́kladem typické mikrostruktury; a - impregnační náteky $\mathrm{CaCO} 3$ na pórech po kořenech (subfacie $A$ ); b - viditelné usměrnění minerální frakce, pod sklonem (přechod mezi subfacií A a B); c - fragment propálené matrix (subfacie B); $\mathrm{d}$ - fragment spálené kosti (subfacie $B$ ). Všechny mikrofotografie byly pořízeny v procházejícím světle (PPL). Autor L. Lisá.

\subsection{Historický kontext a nálezová situace vzorků z lokality Biskupská 7, parcela č. 381 (obr. 20: 3-6).}

Zkoumaná parcela náležející k domu 7 (č. p. 280) je vázána na severní linii Biskupské ulice. Ve středověku se nazývala Parva platea sub scola, později Kanovnická. Umístěna je v jihozápadní části města, na svahu nedaleko od nejvyšší partie Petrského návrší. Ze severní strany vymezovala sakrální okrsek farního kostela sv. Petra a bylo možné z ní postupovat na jedno ze dvou hlavních tržišť města, Horní trh (forum Superior, dnes Zelný trh) nebo k Brněnské bráně v prostoru dnešního Šilingrova náměstí. Archeologický výzkum byl realizován v roce 2014 v souvislosti

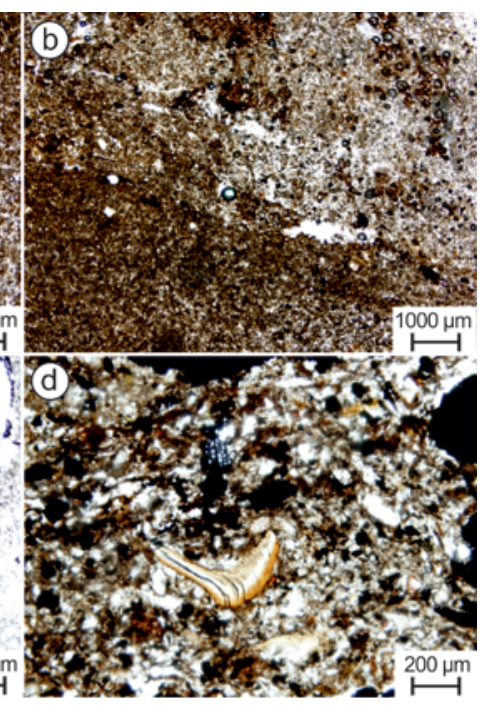

Fig. 6. Basic microstratigraphical division of the floor set documented in the sample A20/4 from the Bašty site with examples of the most common micromorphological features; $a$ - $\mathrm{CaCO} 3$ coatings inside the root channels (subfacie $A$ ); $b$-visible orientation under the angle of mineral fraction (transition between subfacies $A$ and $B$ ); $c$ - fragment of a burned matrix (subfacie $B$ ); $d$ - fragment of a burned bone (subfacie $B$ ). All microphotographs were taken in plane polarised light (PPL). Author L. Lisá.

s generální opravou objektu (Černá et al. 2015) a jeho výsledky byly publikovány společně s historií a stavebním vývojem domu v roce 2016 (Borský et al. 2016). Záchranný výzkum se dotkl především dvorní části parcely, kde přinesl zásadní poznatky ke stavebnímu vývoji a charakteru zástavby z období 13. a 14. století. Do jisté míry potvrdil hypotézu existence dvou původních městišt sloučených později do jedné parcely. Nejstarší zástavba byla nezděná, reprezentoval ji jeden suterén a dále relikty nadzemních částí staveb, které byly identifikovány především podle podlahových úrovní, výkopů pro usazení jednotlivých prvků dřevěné konstrukce a destrukčních planýrek vlastních staveb. 

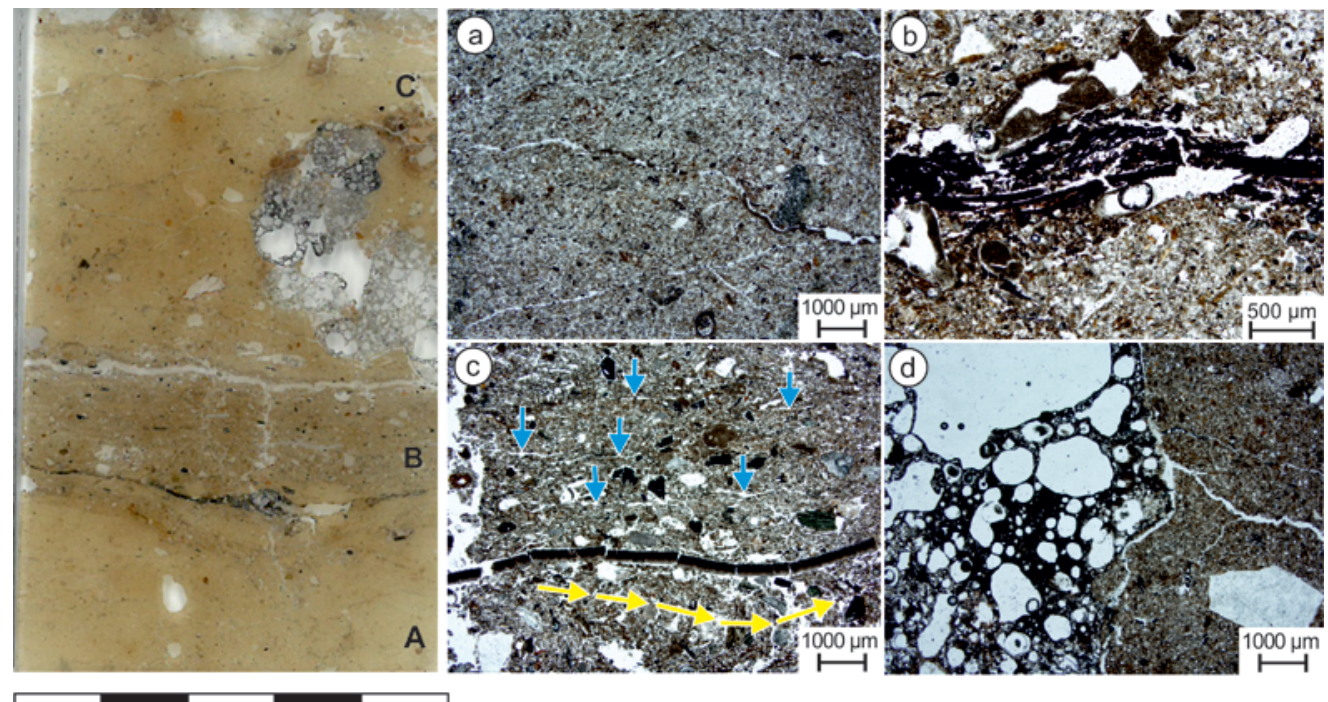

Obr. 7. Základní mikrostratigrafické členění podlahového setu vzorku 1 z lokality Biskupská 7 s př́íladem typické mikrostruktury; a- prasklinová mikrostruktura subfacie A. Některé praskliny jsou vyplněny prachovitými náteky; b - průběžná vrstva spálené organické hmoty na přechodu mezi pasivní a aktivní vrstvou podlahového sendviče (subfacie $A a B$ ); c - v centru je fragmentovaná vaječná skořápka (subfacie B). Pod ní je žlutými šipkami naznačen směr lezení mikrofauny a nad ní modrými šipkami označeny horizontální mikropóry, které svědčí o opakovaném silném tlaku z nadloží; d - fragment strusky ze subfacie $C$. Všechny mikrofotografie byly foceny v procházejícím světle (PPL). Autor L. Lisá.

Do zkoumaného prostoru zřejmě domy v nejstarším období nezasahovaly, resp. nenalezli jsme o tom žádné doklady. Později však došlo $\mathrm{k}$ výstavbě štítově orientovaných budov, které zabraly také části někdejších dvorů. Na západním městišti (prostor sondy S1) se podařilo dokumentovat relikty tří po sobě následujících fází nadzemních dřevohliněných domů (s.s.j. 020-022). Čtvrtou fázi představoval zahloubený suterén (s.s.j. 024). Z nejstaršího období vývoje před výstavbou domů byla $\mathrm{v}$ prostoru sondy S1 dokumentována tři drobná otopná zařízení (Merta et al. 2016). Na východním městišti (prostor sondy S2) byly rozeznány dvě stavební fáze dřevohliněného domu (s.s.j. 002, 003). Ve starším období jim předcházela blíže neurčená nezděná stavba (s.s.j. 011), která však zřejmě stávala pouze v prostoru dvora. Na obou dvorech nelze vyloučit (spíše předpokládat) existenci dalších staveb „lehčí“ konstrukce.

\subsubsection{Vzorek č. 1 - nadzemní část stavby (s.j. 163-162-161)}

Vzorek č. 1 zahrnul v sobě tři uloženiny. Detailní mikromorfologický popis je v tab. 1. Bázi (s.j. 163) a svrchní část (s.j. 161) tvořila okrová plastická hlína, přičemž mohlo jít o hmotu nevypálené mazanice. Tyto vrstvy měly mocnost okolo $5 \mathrm{~cm}$ a byly interpretovány jako konstrukční (sanační) vrstvičky podlahy. Mezi nimi se nacházela vrstvička šedé plastické hlíny (s.j. 162) o mocnosti $1 \mathrm{~cm}$, která zřejmě vznikla jako výsledek komunikačních procesů a úprav podlahy. Odběr vzorku se soustředil především na zachycení této uloženiny za účelem bližšího poznání jejího charakteru a upřesnění interpretace. Dokumentovaná terénní situace totiž nabízela i další interpretační variantu. $\mathrm{Na}$ jiných místech zkoumané plochy totiž popsanému souvrství odpovídala jednolitá vrstva okrové plastické hlíny (s.j. 130), která byla spojena s planýrováním neshořelé partie předchozí stavby s.s.j. 002 a vytvořila konstrukci podlahy nové stavby s.s.j. 003. Ono zvrstvení mohlo vzniknout v krátkém časovém intervalu během nanášení této uloženiny. Zkoumanou část stavby s.s.j. 003 lze považovat za zadní část domu, který byl okapově orientován k uliční linii. K jeho charakteru a konstrukci se nelze
Fig. 7. Basic microstratigraphical division of the floor set documented in sample 1 from the Biskupská 7 site with examples of the most common micromorphological features; a - crack microstructure of subfacie A; some of the cracks are infilled with silty clay coating; $b$ - a continual layer of burned organic matter between the passive and active layer of the floor sandwich (the transition between subfacies $A$ and $B$ ); $C$ - there is a fragmented eggshell in the centre of the photo (subfacie $B$ ); the direction of the passage feature is marked with yellow arrows below the eggshell; above the eggshell are horizontal micropores related to the strong press from the surface marked with blue arrows; $d$ - the fragments of slag from subfacie $C$. All microphotographs were taken in plane polarised light (PPL). Author L. Lisá.

blíže vyjádřit. Ve zkoumaném segmentu se podařilo zachytit doklady svislých konstrukčních prvků v podobě sedmi sloupových a kůlových jamek a dvou větších sloupových jam. Ty nemusely být všechny stejného stáří, je možné, že náležely několika dílčím stavebním fázím (úpravám) stavby. Dle stratigrafické situace a vyhodnocení získaného mobiliáře (především zlomků keramických nádob) lze dobu její existence zasadit do 13. století.

$\mathrm{Z}$ hlediska mikromorfologického popisu výbrusu jej bylo možné rozdělit na tři subfacie označené odspodu jako A, B a C (obr. 7). Detailní mikromorfologické popisy studovaných vzorků jsou uvedeny v tab. 1. Interpretace vzorku Biskupská 1 je následující: pasivní vrstva je vzhledem ke své nehomogenitě tvořena již přemístěným sprašovým sedimentem. Je tedy možné uvažovat o ní jako o konstrukční pasivní vrstvě. Obsahuje množství horizontálních pórů, což nasvědčuje intenzivnímu zatížení z nadloží. Některé z těchto pórů jsou vyplněny prachovitými náteky, což lze interpretovat jako důsledek pronikání roztoků obohacených o prachovitou složku. Nadložní pochozí vrstva je tvořena nášlapem. Ten obsahuje organický kuchyňský odpad, tzn. rozloženou organickou hmotu, skořápky, spálené kosti, uhlíky a zároveň má množství horizontálních puklinek svědčících o intenzivním tlaku z nadloží. Tento tlak se mohl zároveň promítat do podloží, tzn. do subfacie A. Některé z těchto puklinek jsou opět vyplněny prachovitými náteky. Nadložní vrstva tvoří další intencionální pasivní vrstvu, tzn. vrstvu tvořenou přemístěnou spraší. I v této vrstvě jsou dokumentovány prachovité náteky. Jedinou výraznější inkluzí této vrstvy je fragment strusky. Opět jsou zde zastoupeny horizontální póry, i když ne v takové míře jako je tomu u subfacie A a B. Některé z nich jsou vyplněny prachovitými náteky. Přítomnost náteků pravděpodobně př́ímo indikuje praktiky spojené s úpravou podlahy. Př́tomnost jemnozrnného prachu a vody, která jej redeponuje do podloží, svědčí nejspíše o mokrém zametání. Je možné předpokládat, že se nad touto konstrukční pasivní vrstvou nacházela další fáze pochozího horizontu. Náznaky př́tomnosti tohoto horizontu byly detekovány fragmentárně na svrchním okraji této subfacie. 


\subsubsection{Vzorek č. 2 - povrchové úpravy dvora (s.j. 149-144; obr. 20:3)}

Vzorek č. 2 zahrnul v sobě dvě uloženiny. Bázi tvořila tmavě šedá písčitá hlína/hlinitý písek (s.j. 149), svrchní část šedá plastická hlína s četnými zlomky okrové plastické hlíny (s.j. 144). Jeden $\mathrm{z}$ těchto zlomků se nacházel na rozhraní vrstev v pozici, která umožňovala jeho vyčlenění jako samostatného kontextu. Nebylo zcela vyloučeno, zda se dokonce nejedná o planýrku mazanicové konstrukce či konstrukční vrstvu podlahy dřevohliněné stavby. Situace nebyla zcela jasná, poněvadž byla zkoumána jen v dílčím segmentu profilu. Vrstvy s.j. 149 a 144 byly uloženy ve dvorní části zkoumaného městiště. První z nich mohla vzniknout v důsledku komunikace a úpravy povrchu dvora, druhá jako kumulace odpadu nebo planýrka dřevohliněné stavby. Dle stratigrafické situace a vyhodnocení získaného mobiliáře (především zlomků keramických nádob) lze jejich vytvoření zasadit do 13. století. Odběr vzorku měl otestovat možnosti určení původu zmíněného zlomku (vrstvičky) okrové plastické hlíny, která se uložila mezi nimi. Př́ípadné potvrzení náležitosti k podlahové úrovni by do budoucna vyvolalo nutnost věnovat těmto situacím při archeologických výzkumech zvýšenou pozornost.

Z hlediska mikromorfologického popisu byl tento vzorek rozdělen na čtyři subfacie označené jako A, B, C a D odspodu nahoru (obr. 8). Detailní mikromorfologické popisy studovaných vzorků jsou uvedeny v tab. 1. Interpretace vzorku Biskupská 2 je následující: v rámci vzorku byly zachyceny celkem dvě aktivní a dvě pasivní konstrukční vrstvy. Pasivní vrstvy vykazují částečně usměrnění, vesměs jsou však tvořeny spíš poloostrohrannými agregáty. Je otázka, zda vůbec jde o podlahovou vrstvu. Složení těchto vrstev odpovídá depozici kuchyňského odpadu, včetně popela. V případě svrchní subfacie $\mathrm{C}$ je usměrnění zřetelnější, v nejsvrchnější části je dokonce vrstvička artikulovaných fytolitů. Její povrch je však mírně zvlněný, a není vyloučeno, že se jedná o venkovní pochozí horizont. Nebyly zde zachyceny zbytky parazitů nebo exkrementů a v matrix nejsou zřetelné vápnité náteky z prostupujících roztoků, což na druhou stranu zase svědčí spíše o depozici v zastřešeném prostoru. Pasivní vrstvy mezi zmíněnými aktivními vrstvami jsou tvořeny redeponovanou spraší jen mírně kontaminovanou klasty metabazitových hornin.

\subsubsection{Vzorek č. 4 - nadzemní část stavby (s.j. 225-226-227; obr. 20:4)}

Vzorek č. 4 zahrnul v sobě tři uloženiny. Bázi tvořila okrová plastická hlína, přičemž mohlo jít o hmotu nevypálené mazanice (s.j. 225). Interpretována byla jako konstrukční vrstva podlahy, původem snad z planýrky dřevohliněné konstrukce. Na ní byla uložena přibližně $1 \mathrm{~cm}$ silná vrstvička okrově šedé plastické hlíny (s.j. 226), která se zřejmě utvořila v důsledku komunikačních procesů a úpravy podlahy. Následovala vrstva šedé písčité hlíny s četnými kamínky a kameny, určená jako navážka či planýrka (s.j. 227). Odběr vzorku se soustřredil především na zachycení komunikační vrstvičky za účelem bližšího poznání jejího charakteru a upřesnění interpretace. Podlahová úroveň náležela nadzemní části dřevohliněné stavby s.s.j. 011. Protože situace byla dokumentována pouze na profilu, není možné se k rozsahu a charakteru stavby blíže vyjádřit. Na základě stratigrafie a nálezů keramiky lze stavbu zasadit do 13. století. Byla stratigraficky starší než stavba s.s.j. 003, z níž byl odebrán vzorek č. 1 .

Mikromorfologicky byl vzorek č. 4 rozdělen na tři subfacie označené jako A, B a C (obr. 9) odspodu nahoru. Detailní mikromorfologické popisy studovaných vzorků jsou uvedeny v tab. 1. Interpretace vzorku Biskupská 4 je následující: subfacie A detekována na bázi vzorku je tvořena relativně vytříděným prachovitým materiálem, který obsahuje zbytky rozkládající se organické hmoty. Ta jednak při odplynění vytvořila specifické póry, za druhé huminové z rozkládající se organické hmoty byly nabohaceny hydroxidy železa a dávají subfacii typické zabarvení.
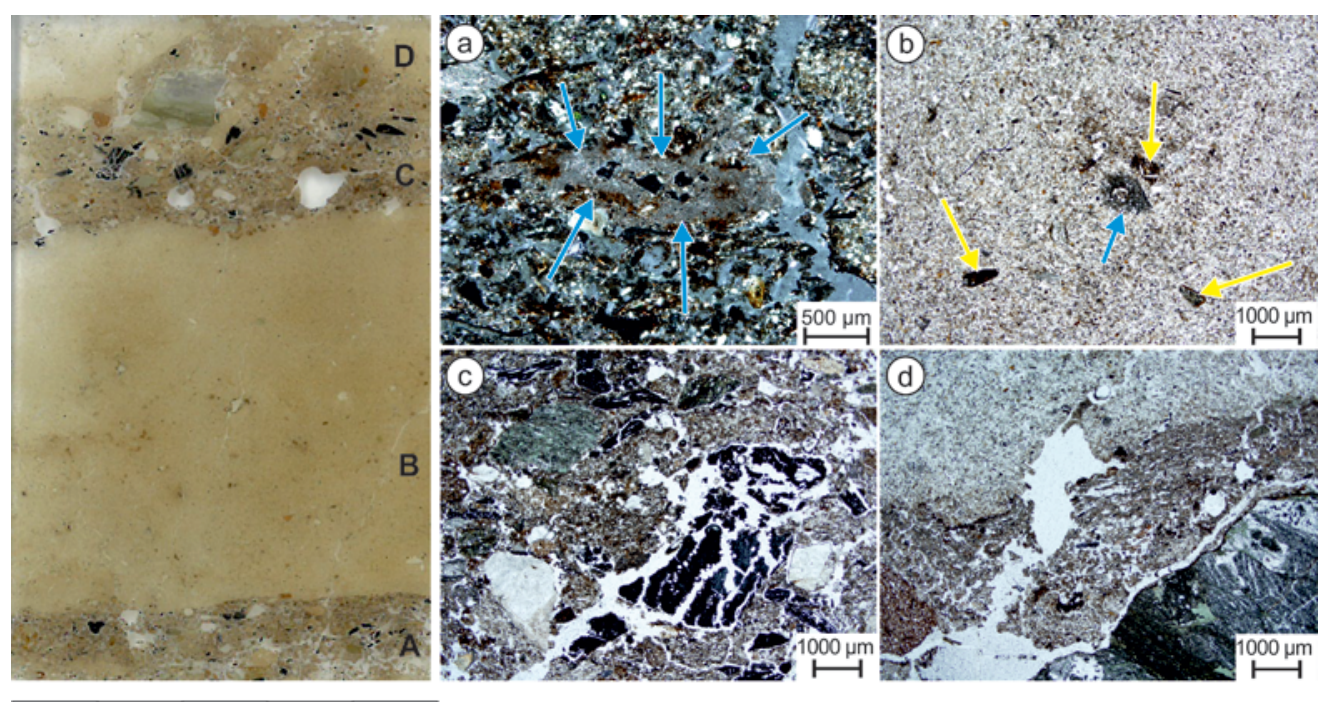

Obr. 8. Základní mikrostratigrafické členění podlahového setu vzorku 2 z lokality Biskupská 7 s př́kladem typické mikrostruktury; a - akumulace mikritického karbonátu v těsné souvislosti s mikrouhlíky (označeno modrými šipkami) indikuje prítomnost popela (subfacie $A$ ); b - relativně homogenní subfacie $B$ obsahuje pouze fragmenty metabazitových hornin nebo zlomený fragment karbonátového náteku. Mikrostrukturu má masivní s minimem pórů; c - aktivní vrstvy v tomto případě jen zřídkakdy vykazují usměrnění, většinou jde o fragmenty hornin, uhlíků a půdních agregátů (subfacie $C$ ); d - nejsvrchnější část aktivní subfacie označené jako $C$ je typická průběžnou vrstvou usměrněné matrix s artikulovanými fytolity. Mikrofotografie a byla pořízena ve světle procházejícím přes zkř́ižené nikoly, mikrofotografie b, c, d potom v procházejícím světle (PPL). Autor L. Lisá.
Fig. 8. Basic microstratigraphical division of the floor set documented in sample 2 from the Biskupská 7 site with examples of the most common micromorphological features; accumulation of micritic carbonate in close connection with microcharcoal (marked with blue arrows) indicates the presence of ash (subfacie $A$ ); $b$ - the relatively homogenous subfacie $B$ contains only fragments of metabazite rocks or a broken fragment of carbonate coating; its microstructure is massive with a minimum of pores; c - active layers in this case only rarely show the internal orientation of the matrix; the orientation is usually marked by the position of rock fragments, charcoal and soil fragments (subfacie $C$ ); $d$ - the uppermost part of subfacie $C$ is characteristic for the presence of a continually oriented matrix with articulated phytoliths. The microphotograph a was taken in cross polarised light (XPL) the microphotographs b, c, d in plane polarised light (PPL). Author L. Lisá. 
Bud’to jde o pasivní vrstvu, do které byla cíleně přidávána organická hmota, nebo jde o destrukci mazanice, do které byla přidávána organická hmota. Aktivní nášlapová vrstva je tvořená především akumulací kuchyňského odpadu, včetně popele. Nejsou zde známky usměrnění, je otázkou, jak dlouho tato plocha byla využívána, vrstva není průběžná ve stejné mocnosti, a místy až mizí. Mezi pasivní a aktivní vrstvou vznikla tzv. reaktivní vrstva tvořená impregnacemi fosfátů z rozkládajících se kostí. Makroskopicky se tato vrstvička projevuje jako tenká oranžová linka. Vrstva je sanována materiálem redeponované spraše.

\subsubsection{Vzorek s.j. 266-249 - nadzemní část stavby nebo její planýrky (vrstvy s.j. 266-249; obr. 20: 5)}

Vzorek s.j. 266-249 zahrnul v sobě dvě uloženiny. Bázi tvořila světle rezavohnědá až rezavookrová plastická hlína (s.j. 266), svrchní část šedookrová plastická hlína se zlomky šedé plastické hlíny (s.j. 249). První byla interpretována jako planýrka konstrukce dřevohliněné stavby s.s.j. 020, druhá jako planýrka stavby s.s.j. 021, přičemž první z nich mohla tvořit základovou vrstvu podlahy druhé stavby. Důvodem odebrání vzorku z rozhraní těchto uloženin a jeho analýzy bylo potvrzení či vyvrácení existence a určení
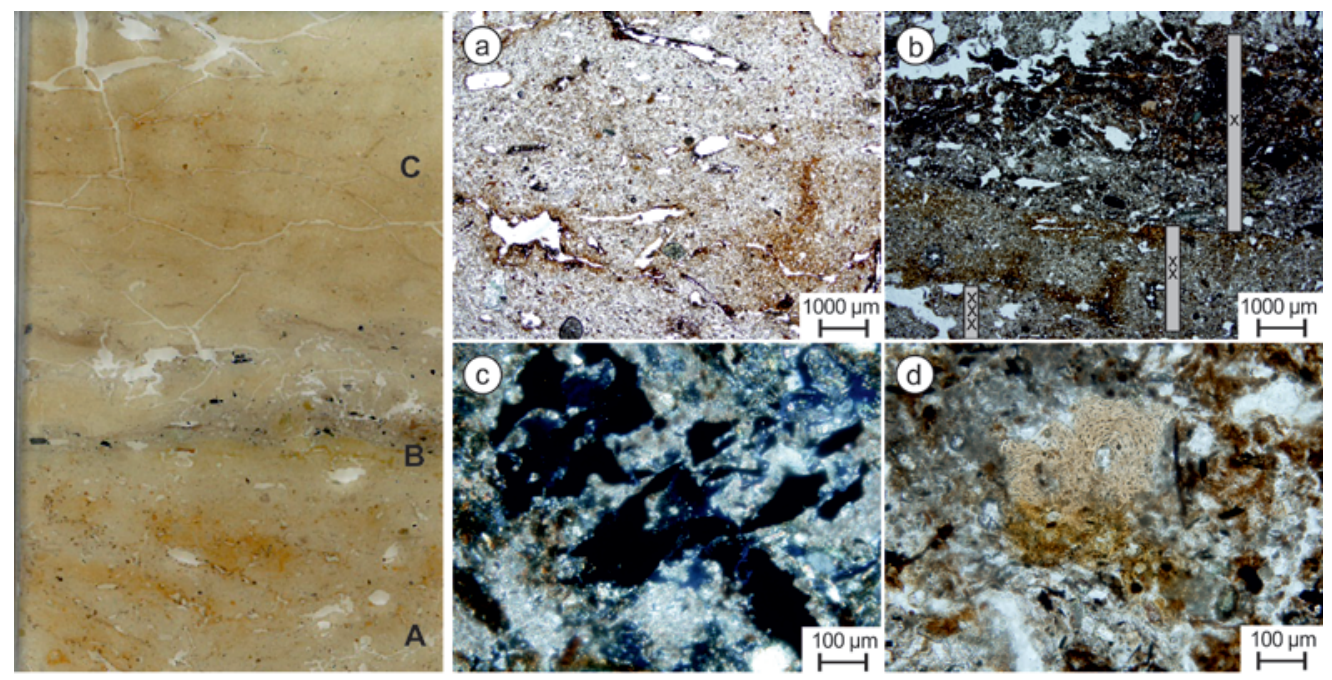

0

$5 \mathrm{~cm}$

Obr. 9. Základní mikrostratigrafické členění podlahového setu vzorku 4 z lokality Biskupská 7 s př́íladem typické mikrostruktury; a - praskliny vznikající odplyněním organické hmoty se zbytky rozložené organické hmoty a impregnacemi hydroxidy železa (subfacie A); b - set aktivní (x), reaktivní (xx) a pasivní (xxx) vrstvy (přechod mezi subfacií A a B); c - uhlíky v kombinaci s mikritickým karbonátem reprezentující zbytky popela (svrchní část subfacie B); d - rozkládající se mikroúlomek kosti (subfacie B). Mikrofotografie $\mathrm{c}$ byla pořízena v světle procházejícím zkř́íženými nikoly (XPL), mikrofotografie a, $c, d$ byly pořízeny v procházejícím světle (PPL). Autor L. Lisá.
Fig. 9. Basic microstratigraphical division of the floor set documented in sample 4 from the Biskupská 7 site with examples of the most common micromorphological features; a - cracks originating as a result of organic matter decomposition partly infilled by the fragments of decomposed organic matter and partly impregnated by Fe hydroxides (subfacie $A$ ); $b$ - sandwich of active $(x)$, reactive $(x x)$ and passive ( $x x x$ ) layers documenting the transition between $A$ and $B$ subfacies; $c$ - charcoal together with the micritic carbonate representing the ash relicts (upper part of subfacie B); $d$ - partly decomposed bone fragment (subfacie B). Microphotograph c was taken in cross polarised light (XPL), microphotographs $a, b, d$ were taken in plane polarised light (PPL). Author L. Lisá.
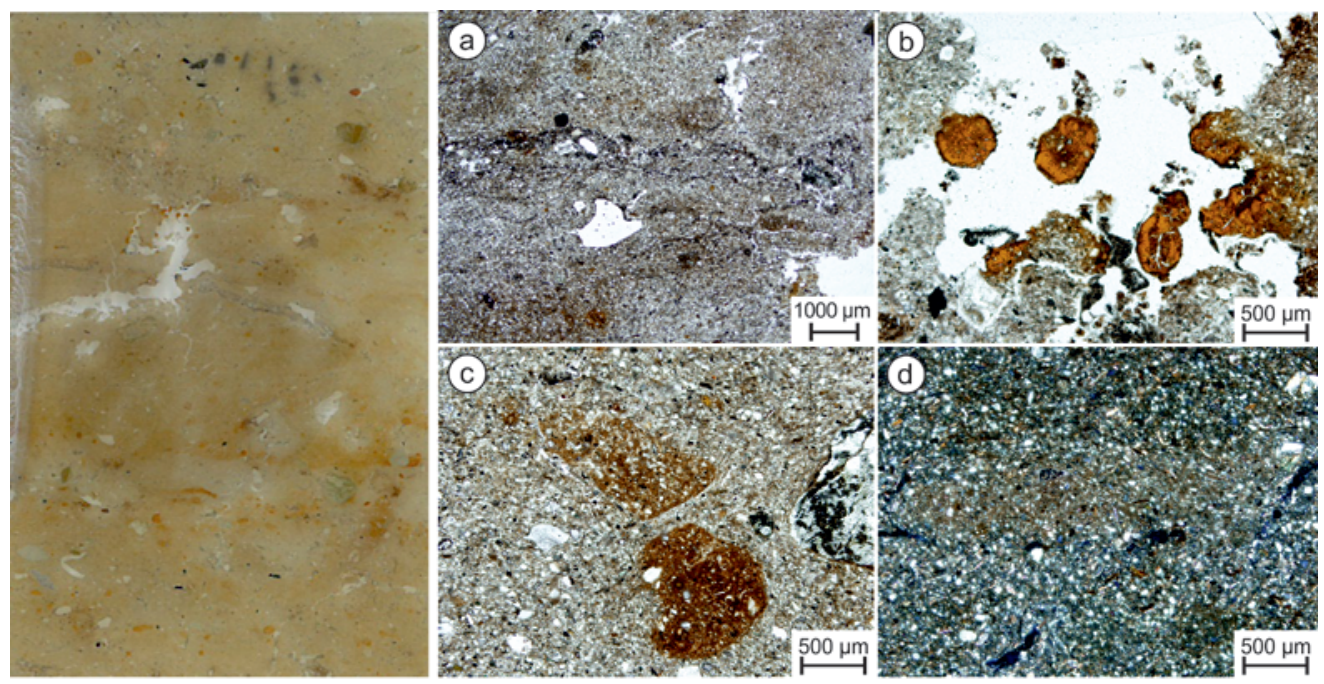

Obr. 10. Základní mikrostratigrafické členění podlahového setu vzorku 226-249 z lokality Biskupská 7 s př́kladem typické mikrostruktury; a - neprůběžná mikrovrstvička akumulace mikrouhlíků; b - fosfatické nodule; c - nodule hydroxidu železa; $d$-impregnace karbonátů. Mikrofotografie a, b, c byly pořízeny v procházejícím světle ( $P P L)$, mikrofotografie $d$ byla pořízena ve světle procházejícím přes zkřížené nikoly (XPL). Autor L. Lisá.
Fig. 10. Basic microstratigraphical division of the floor set documented in samples 226-249 from the Biskupská 7 site with examples of the most common micromorphological features; a - non-continuous layer of microcharcoal accumulation; $b$ - phosphatic nodule; $c$ - $\mathrm{FeOH}$ nodule; $d$-carbonate impregnation. Microphotographs a, b, c were taken in plane polarised light (PPL); microphotograph d was taken in cross polarised light (XPL). Author L. Lisá. 
charakteru podlahové vrstvičky stavby s.s.j. 021. Při výzkumu se výrazným zpo̊sobem neprojevila. U obou staveb je možné uvažovat o domech štítově orientovaných k uliční čáře, přičemž výzkum se dotkl jejich dvorních (zadních) částí. Zkoumány byly jen nepatrné segmenty, proto přesný charakter a půdorys domů zůstal neznámý. V případě stavby s.s.j. 021 byla odkryta jen dílčí partie v těsné blízkosti severní obvodové stěny, jejíž základ tvořil horizontálně uložený trám. Dle stratigrafické situace a vyhodnocení získaného mobiliářre (především zlomků keramických nádob) lze dobu existence obou staveb zasadit do 13. století, přesněji před výstavbu suterénu s.s.j. 024, z jehož výdřevy bylo získáno dendrodatum vymezené intervalem 1257 až 1272 (Černá et al. 2015).

Mikromorfologicky nebyl vzorek rozčleněn na žádné mikrofacie (obr. 10). Detailní mikromorfologické popisy studovaných vzorků jsou uvedeny v tab. 1. Interpretace: $\mathrm{V}$ případě vzorku Biskupská 249/266 nebyla indikována žádná pochozí vrstva. Matrix jeví známky redeponované spraše nebo omazu bez organické hmoty a je silně postdepozičně ovlivněna pochody, které probíhaly v nadloží.

\subsubsection{Vzorek s.j. 283-284 - suterén (obr. 20: 6)}

Vzorek s.j. 283-284 zahrnul v sobě dvě uloženiny z podlahové úrovně suterénu dřevohliněné stavby (s.s.j. 024; obr. 20: 6). Bázi tvořila šedá plastická/písčitá hlína s nahodilými uhlíky, kamínky a zlomky vypálené mazanice (s.j. 283), svrchní část světle šedá plastická hlína s nahodilými uhlíky (s.j. 284). Suterén byl utvořen výkopem, který měl čtvercový nebo obdélný půdorys o rozměrech $3,30 \times>1,80 \mathrm{~m}$. Dokumentovaná hloubka činila 2,40 m. V existenci suterénu bylo možné rozpoznat dvě základní fáze. K první patřila podlahová (komunikační) vrstvička překrývající dno výkopu (s.j. 283). Následně byla pochozí úroveň interiéru zvýšena o 0,25 m prostřednictvím vrstvy s.j. 284. Poté byla do suterénu vsazena dřevěná konstrukce stěn. Původně ji představovaly horizontálně uložené desky (shořelé relikty se zachovaly při severní stěně), v severozápadním rohu byly zasunuty za dřevěný sloup. Prostor mezi deskami a stěnou (o šířce 10 až $30 \mathrm{~cm}$ ) vyplňovala okrová, plastická hlína. Dle určených vzorků bylo na konstrukci užito dřevo dubu a jedle. Stavba a suterén zanikly požárem, přičemž suterén byl z velké části vyplněn požárovou destrukcí. Horní část byla zasypána uloženinou, která měla odpadní charakter. Suterén mohl tvořit podsklepení zadní partie domu, který by byl štítově orientován k Biskupské ulici. Zadní stěna suterénu byla vzdálena 13 m od uliční čáry Biskupské ulice. Př́ípadně mohl náležet stavbě stojící ve stř̌ední části parcely. Smýcení stromu, ze kterého byl vyroben sloup výdřevy suterénu, bylo dendrochronologicky usazeno do období 1257 až 1272. Keramické zlomky z požárové destrukce a následujících zásypů suterénu byly datovány do období 2 . poloviny 13 . a 1. poloviny 14. století. Vzorek lze z hlediska mikrostruktury rozdělit na dvě hlavní subfacie označené jako A a B (obr. 11).

Detailní mikromorfologické popisy studovaných vzorků jsou uvedeny v tab. 1. Interpretace je následující: tento podlahový set je silně ovlivněn postdepozičně, pravděpodobně ve spojení s nějakou výrobou. Samotná pasivní vrstva je starší destrukce tvořená nevytřríděným sedimentem. Aktivní vrstva je tvořena nejméně třemi mikrovrstvami horizontálně uložené organické hmoty, které se projevují akumulací artikulovaných fytolitů. Množství uhlíků, propálené matrix, spálených kostí a akumulací strusky nutně vedlo $\mathrm{k}$ intenzivnímu postdepozičnímu ovlivnění jak samotné aktivní, tak i pasivní vrstvy. Přítomnost prosakujících roztoků není znázorněna pouze náteky, ale také tvorbou Fe/Mn nodulí. Aktivity spojené s výrobní činností pravděpodobně způsobily změnu $\mathrm{pH}$ a došlo $\mathrm{k}$ migraci jílovýchz minerálů, jejichž náteky a impregnace jsou četné jak v aktivní, tak v pasivní vrstvě.

\subsection{Historický kontext a nálezová situace vzorků z lokality Orlí 19, parcela č. 165/1 (obr. 21: 4 - viz níže)}

Zkoumaná parcela náležející dnes k domu 19 (č. p. 710) je vázána na severní linii Orlí ulice, ve středověku se ovšem nazývala Měnínská (platea Menensis). Nacházela se v jihovýchodní části města a spojovala Měnínskou bránu s Horním trhem (Zelný trh) a do jisté míry se v ní odráží část linie původní komunikace vedoucí od Starého Brna na Cejl a dále do Zábrdovic. Záchranný
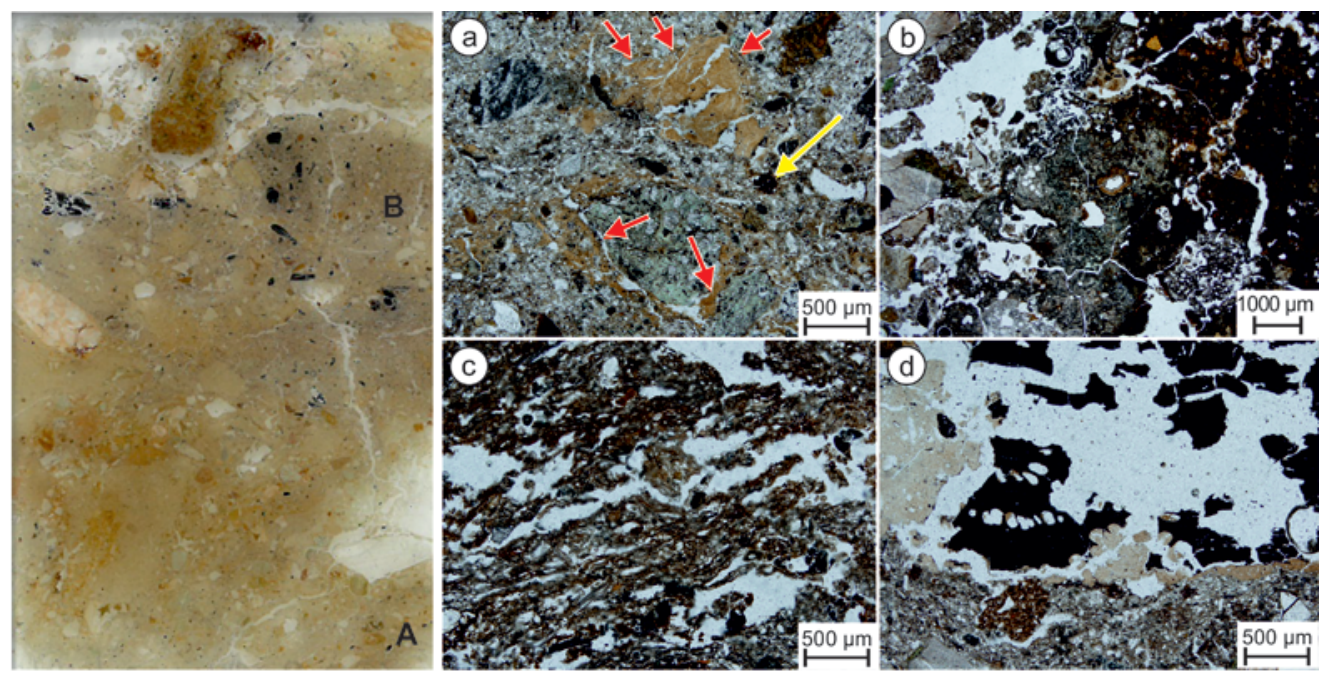

0

$5 \mathrm{~cm}$

Obr. 11. Základní mikrostratigrafické členění podlahového setu vzorku 283-284 z lokality Biskupská 7 s př́íkladem typické mikrostruktury; a - nevytříděný sediment pasivní vrstvy (subfacie A), který obsahuje množství jílovitých nátekủ (červená šipka) a další pedogenní prvky jako například nodule Fe/Mn (žlutá šipka); b - struska ze subfacie B; c - akumulace artikulovaných fytolitů ve subfacii B; d - jílovité náteky ve spojení s akumulacemi uhlíků ve facii $B$. Všechny mikrofotografie byly pořízeny v procházejícím světle (PPL). Autor L. Lisá.
Fig. 11. Basic microstratigraphical division of the floor set documented in samples 283-284 from the Biskupská 7 site with examples of the most common micromorphological features; a - unsorted material of the passive layer (subfacie $A$ ) containing clay coating (red arrow) and other pedogenic features as, for example, $\mathrm{Fe} / \mathrm{Mn}$ nodules (yellow arrow); $b$ - slag fragment from subfacie $B ; C$ - the accumulation of articulated phytoliths from subfacie $B ; d$ - clay coating linked to the charcoal accumulation in subfacie B. All microphotographs were taken in plane polarised light (PPL). Author L. Lisá. 
archeologický výzkum byl vyvolán realizací projektu výstavby hudebně dramatické laboratoře Janáčkovy akademie múzických umění v Brně a probíhal v několika etapách v letech 2008 až 2012 (Černá et al. 2012, 119-121; Holub 2012). Výzkum potvrdil, že v daném prostoru se rozvíjelo osídlení ještě před založením města ve 2 . polovině 12 . století. Postupně se zřejmě začalo přetvářet a dostávat charakter městské zástavby. Její zástupce představují odhalené segmenty dvou suterénů dřevohliněných staveb (s.j. 151 a s.s.j. 12-13). Tento kontinuální vývoj byl snad přerušen před polovinou 13. století lokací minoritského kláštera v těsném sousedství. V průběhu 14. století doklady o výrazném osídlení známém z ostatních částí středověkého Brna chybí. Další výrazné osídlení přichází až z 15. století a nese s sebou všechny typické znaky, jako je stavba zděných staveb, budování odpadních jímek a další. Zmíněné suterény pravděpodobně reprezentují zástavbu dvou původních městište V případě jejich orientace k Orlí (Měnínské) ulici by se nacházely v zadní části pozemků. Je ovšem otázkou, zda parcelace prostoru v počátcích města nebyla odlišná a dnešní podoba je až výsledkem změny vyvolané postupnou výstavbou minoritského kláštera. Spolehlivější písemné zprávy o topografii tohoto prostoru máme z městských knih bohužel až z průběhu 14. století.

\subsubsection{Vzorek s.j. 151 - vrstva pod nadzemní částí stavby}

Vzorek byl odebrán z vrstvy s.j. 151, která se nacházela v zadní částí parcely (za předpokladu její orientace k Orlí ulici). Vrstva s.j. 151 byla situována př́mo na sprašovém podloží. Její mocnost se pohybovala okolo $20 \mathrm{~cm}$. Tvořena byla šedou plastickou hlínou s nahodilým výskytem malých uhlíků, zlomků keramiky, železné strusky a zvířecích kostí, byla tudíž interpretována jako odpadní. Díky depozici materiálu této vrstvy mohlo dojít k vyrovnání terénu před výstavbou jmenované stavby. Vyloučena však není možnost, že jde o výplň staršího objektu. Na povrchu se nacházelo souvrství drobnějších vrstviček, které lze spojovat s podlahovou úrovní nadzemní části dřevohliněné stavby. Odebráním a určením vzorku mělo dojít k upřesnění charakteru a interpretace setu vrstev.
Ve vzorku nebyly vyčleněny žádné subfacie (obr. 12). Detailní mikromorfologické popisy studovaných vzorků jsou uvedeny v tab. 1. Interpretace vzorku, resp. nálezové situace je následující: vzorek je tvořen redeponovanou spraší. Pravděpodobně nebyl součástí omazu, nepálených cihel nebo jiných konstrukčních prvků, protože obsahuje naprosté minimum příměsí. Je nicméně pravděpodobné, že byl vystaven na povrchu, protože je silně bioturbován.

\subsubsection{Vzorky 75/08/05, 75/08/06 a 75/08/07 ze s.s.j. 012-013 - suterén; obr. 21: 4)}

Vzorky byly odebrány ze suterénu s.s.j. 012-013, jenž byl tvořen výkopem, který měl čtvercový nebo obdélný půdorys. Dokumentován byl však jen segment severozápadního nároží o rozměrech $2,70 \times 1,60 \mathrm{~m}$ a hloubce 1,60 $\mathrm{m}$ (původní hloubka snad až 2,20 m). Podlahová úroveň byla tvořena tenkou vrstvičkou šedé plastické hlíny s nahodilými uhlíky (s.j. 368), která př̀krývala dno výkopu a zřejmě vznikla v důsledku komunikačních procesů. Na ní ležela vrstvička okrové plastické hlíny (s.j. 367), kterou lze snad interpretovat jako následnou úpravu podlahy. Z těchto podlahových úrovní byl odebrán vzorek 75/08/05. Překryla je v průměru $0,20 \mathrm{~m}$ silná požárová destrukce (s.j. 366). Následující vrstva okrové plastické hlíny s mezivrstvičkami šedé plastické hlíny (s.j. 384) byla určena jako komunikační a měla by souviset $\mathrm{s}$ druhou fází suterénu se zvýšenou úrovní podlahy (s.s.j. 013). Z dolní části vrstvy byl odebrán vzorek 75/08/06, z horní vzorek 75/08/07. Další výplně mohly mít původ v neshořelé části dřevohliněné konstrukce, nebo pocházejí z výkopu mladší, do podloží hloubené jámy. Keramický materiál získaný z výplní byl datován do 1. poloviny 13. století. Zánik suterénu v období kolem poloviny 13. století potvrzuje rovněž materiál získaný ze stratigraficky souvisejících situací. Je otázkou, zda předpokládaná druhá fáze suterénu nebyla jen krátkodobou jednorázovou záležitostí, kterou je možné spojit např́iklad se zasypáváním zaniklého suterénu či jinou činností než obnovou funkce suterénu.
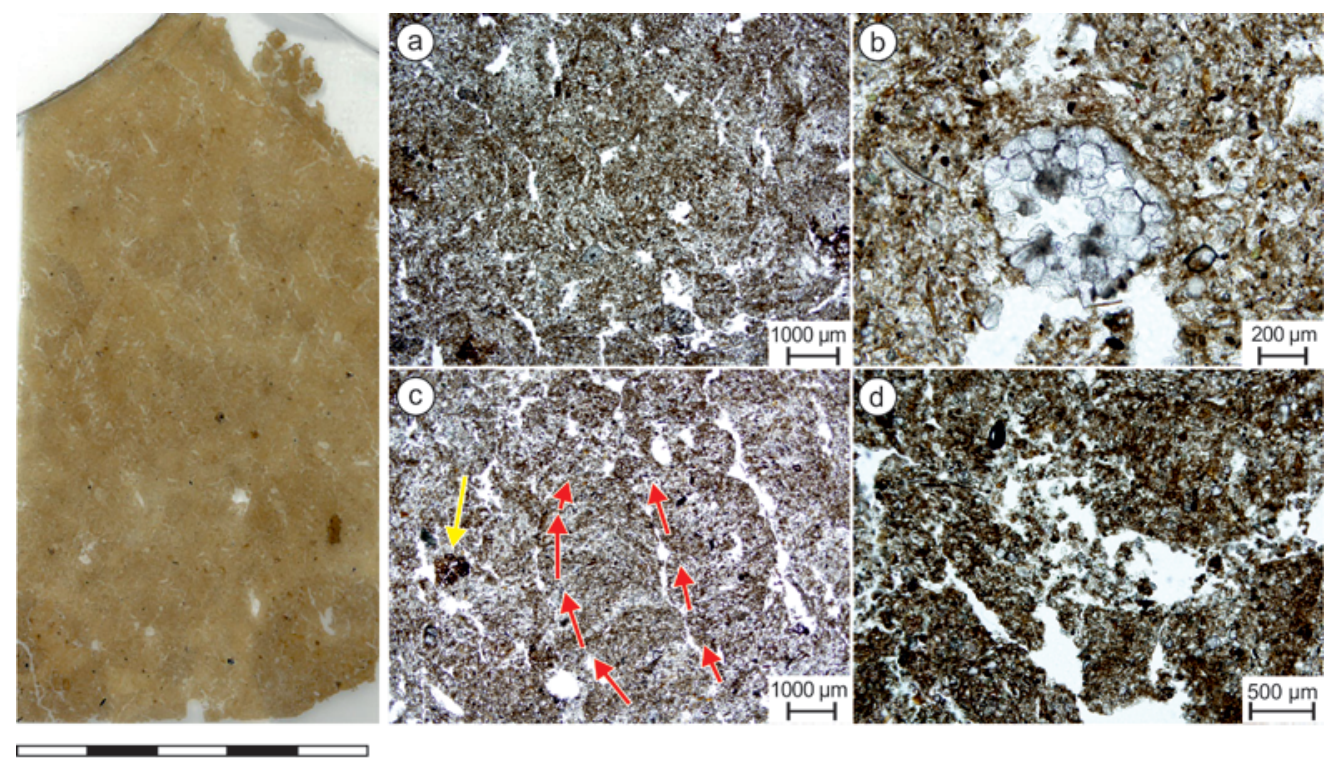

Obr. 12. Základní mikrostratigrafické členění podlahového setu vzorku 151 z lokality Orlí 19 s př́kladem typické mikrostruktury; a - silně bioturbovaný vzorek; b - sparitické karbonáty jako pseudomorfózy po kořenových buňkách; c - směr bioturbace červeně, př́ítomnost Fe/Mn nodule označena žlutě; $d$ - exkrementy mikrofauny. Všechny mikrofotografie byly pořízeny v procházejícím světe (PPL). Autor L. Lisá.
Fig. 12. Basic microstratigraphical division of the floor set documented in sample 151 from the Orlí 19 site with examples of the most common micromorphological features; strongly bioturbated sample; $b$ - sparitic carbonates as pseudomorphoses after the root cells; $c$ - the direction of bioturbation is marked in red, the presence of Fe/Mn is highlighted in yellow; $d$ - microfauna excrements. All microphotographs were taken in plane polarised light (PPL). Author L. Lisá. 


\subsubsection{Vzorek 75/08/05 - suterén (s.s.j. 012-013; obr. 21: 4)}

Ve vzorku bylo možné vyčlenit tři subfacie označené jako A, B a C (obr. 13). Detailní mikromorfologické popisy studovaných vzorků jsou uvedeny v tab. 1. Interpretace: podlahový set je tvořený dvěma pasivními vrstvami, z nichž spodní je nekonstrukční, a svrchní je konstrukční, tzn. byla pro tento účel záměrně př̀ipravena. Ta je mírně ovlivněna ve svrchní části bioturbací, která souvisí s př́tomností organické složky v aktivní vrstvě. Svrchní pasivní vrstva je velmi dobře vytrríděna a odpovídá tzv. plavené hlíně. K sedimentaci muselo dojít částečně ve sloupci vody, protože je ve vzorku viditelná pozitivní gradace sedimentu. Př́tomnost vody před sedimentací aktivní vrstvy se odráží zároveň v deplečních strukturách subfacie B. Aktivní vrstva podlahového setu je potom tvořena běžným kuchyňským odpadem spolu s minerální matrix. Nejsou zde žádné známky usměrnění, vzorek je silně bioturbován a nenese žádné známky opakovaných úprav povrchu.

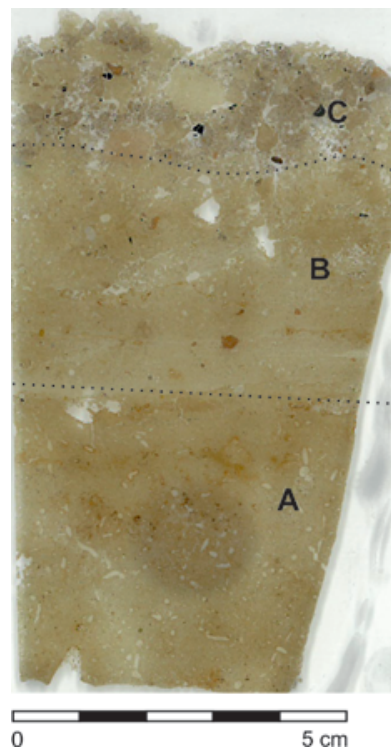

Obr. 13. Základní mikrostratigrafické členění podlahového setu vzorku 75/08/05 z lokality Orlí 19 s príkladem typické mikrostruktury; a- pseudomorfózy sparitického karbonátu po kořenových buňkách (subfacie $A$ ); b - vytříděnost a pozitivní gradace spolu s iluviační laminou v subfacii B; C - agregáty bioturbované matrix s viditelnými stopami po lezení (subfacie C); $d$ - exkrementy mikrofauny (subfacie C). Všechny mikrofotografie byly pořízeny v procházejícím světle (PPL). Autor L. Lisá.

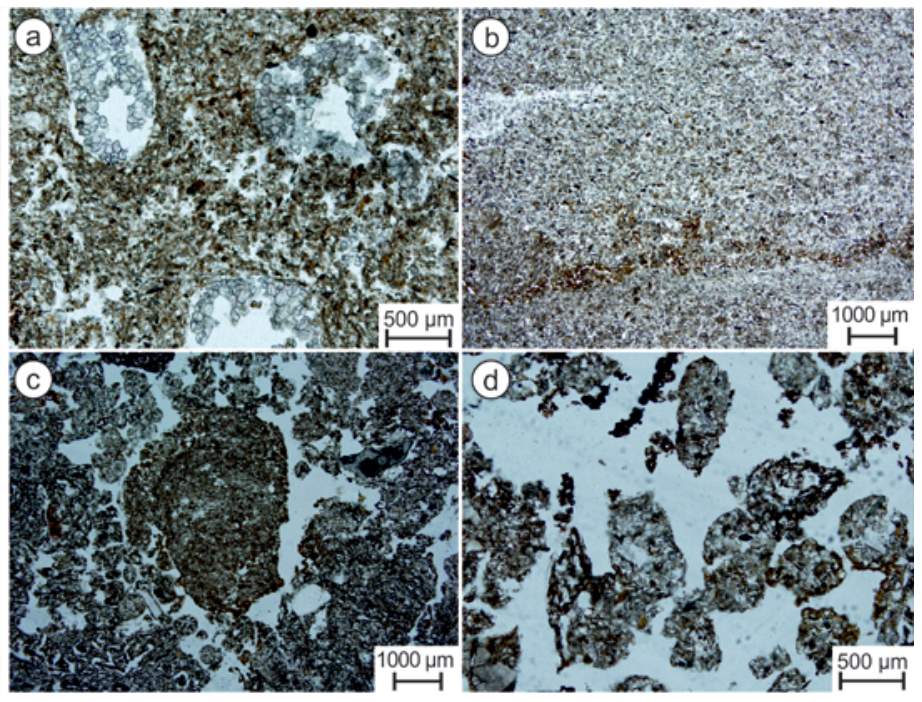

Fig. 13. Basic microstratigraphical division of the floor set documented in sample 75/08/05 from the Orlí 19 site with examples of the most common micromorphological features; a - sparitic carbonate pseudomorphoses after the root cells (subfacie $A$ ); $b$-sorting and positive gradation, together with the illuviation laminae in subfacie $B ; C$ - aggregate of a bioturbated matrix with a still visible passage feature (subfacie $C$ ); $d$ - microfauna excrements (subfacie $C$ ). All microphotographs were taken in plane polarised light (PPL). Author L. Lisá.

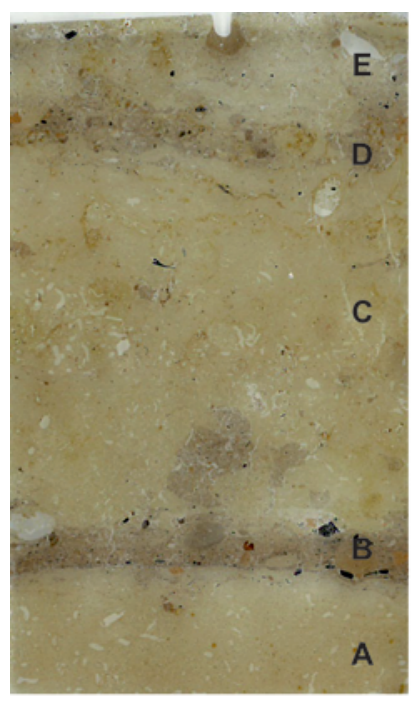

0

Obr. 14. Základní mikrostratigrafické členění podlahového setu vzorku 75/08/06 zlokality Orlí 19 s př́kladem typické mikrostruktury; a - vrstvička rozložené organické hmoty na přechodu mezi facií A a B (modré šipky); b - červené šipky ukazují na fekální sferulity, které byly detekovány jako akumulace v rámci subfacie B a reprezentují exkrement býložravce nebo všežravce; c - subfacie $D$ je tvořena závalky propálené matrix (žluté šipky), rozkládající se organickou hmotou (modrá šipka), ale i kuchyňským odpadem reprezentovaným uhlíky nebo například fragmenty spálených kostí (červená šipka); d - v subfacii D je hojná bioturbace, zde ukázka výplně stopy po lezení tvořená fosfatickou matrix z dekomponované organické hmoty. Mikrofotografie a, $c$, d byly pořízeny v procházejícím světle (PPL), mikrofotografie b ve světle procházejícím přes zkřížené nikoly (XPL). Autor L. Lisá.
Fig. 14. Basic microstratigraphical division of the floor set documented in the sample 75/08/06 from the Orlí 19 site with examples of the most common micromorphological features; a - the layer of decomposed organic matter at the transition between layers $A$ and $B$ (blue arrows); $b$ - red arrows shows phaecal spherulites detected as the accumulation in subfacie $B$ and which represents herbivore or omnivore excrement; $c$ - subfacie $D$ is composed of subrounded fragments of a burned matrix (yellow arrows); by partly decomposed organic matter (blue arrow) as well as by a kitchen dump represented by charcoal or burned bone fragments (red arrow); $d$ - there is quite a common bioturbation in subfacie $D$; an example of a phosphatic infill related to the decomposed organic matter inside the passage feature. Microphotographs a, c, d were taken in plane polarised light (PPL), while microphotograph b was taken in cross polarised light (XPL). Author L. Lisá. 


\subsubsection{Vzorek 75/08/06 - suterén (s.s.j. 012-013)}

Ve vzorku Orlí 75/08/06 bylo možné vyčlenit celkem pět subfacií označených jako A, B, C, D a E (obr. 14). Detailní mikromorfologické popisy studovaných vzorků jsou uvedeny v tab. 1. Interpretace studovaného podlahového sendviče je následující: na bázi byly detekovány spraše pravděpodobně in situ. Tvoří nekonstrukční pasivní zónu. Na ni nasedá aktivní zóna, která má na bázi, jež tvoří ostrou hranici, průběžnou vrstvičku nespáleného dřeva. Aktivní vrstva jako taková je tvořena převážně kuchyňským odpadem a je částečně usměrněna. Usměrnění je viditelné jednak díky orietnaci protáhlých fragmentů organické hmoty, jednak i díky usměrnění minerální matrix, které vzniklo mechanickou úpravou povrchu (zametání). Na povrchu usměrněné vrstvy byly detekovány zbytky exkrementu býložravců nebo všežravců, jde však o ojedinělý nález. Aktivní vrstva je převrstvena další pasivní vrstvou, kterou tvoří redeponovaná spraš. Má minimum inkluzí, a nejde tedy pravděpodobně o destrukci konstrukčního prvku. Další aktivní zóna (subfacie D) je velmi špatně vyvinuta a jde o krátkodobý nášlap spojený s depozicí uhlíků, fragmentů hornin a organické hmoty. Ta je intenzivně bioturbována. Nadložní, pravděpodobně pasivní vrstva nebo zásyp je tvořen redeponovanou spraší. Obsahuje množství minerálních inkluzí a je možné, že jde o destrukci konstrukčního prvku.

\subsubsection{Vzorek 75/08/07 - suterén (s.s.j. 012-013; obr. 21: 4)}

Zde byly vyčleněny tři subfacie označené jako $A, B$ a $C$ (obr. 15). Detailní mikromorfologické popisy studovaných vzorků jsou uvedeny v tab. 1. Interpretace: spodní pasivní vrstva označená jako subfacie A je tvořena vytř́íděnou spraší a obsahuje množství horizontálních pórů. Ty vznikly mechanickým tlakem z nadloží, tj. z horizontu aktivní zóny. Následně došlo k pronikání roztoků bohatých na železo a fosfáty a začaly se tvořit náteky na těchto pórech, nebo impregnace matrix. Samotná aktivní vrstva je tvořená usměrněnou minerální matrix. Občas jsou zde zřetelné fytolity, usměrnění matrix je však dáno mechanicky. Spolu s prrítomností iluviálních vrstviček a pronikajících roztoků do podloží je zřejmé, že se jednalo o mokré zametání. Jinak je tato vrstva tvořena kuchyňským odpadem, ale převažuje minerální matrix. Nadložní pasivní vrstva je nevytř́íděná, a i když je primárním zdrojem spraš, je možné, že jde vzhledem k obsahu inkluzí o destrukci nějakého konstrukčního prvku.

\subsection{Historický kontext a nálezová situace vzorků z lokality Panenská 1, parcela č. 501/1 (obr. 21: 1-3)}

Vzorky byly odebrány při akci A014/2009, která byla vyvolána záměrem výstavby parkovacího domu v místě tř́i středověkých parcel při středověkém hradebním pásmu v ulici Panenská. Již od 14. století měla ulice svůj dnešní název (platea Monialium), související s nárožním „markrabským“ domem, tehdy v držbě starobrněnských cisterciaček. Náležela čtvrti Veselé (quartale Letorum). Podle zápisů z rejstř́íků městské sbírky z poloviny 14. století se jednalo o periferní, méně zdaněné městiště s daní 0,5 groše. Podle rejstříku městské sbírky z r. 1348 bylo v Panenské ulici 26 domů. Vlastníci pozemků, na kterých se uskutečnil archeologický výzkum, byli v rejstřících zřídka uváděni, a v letech 1346 a 1350 by mohli být majiteli „pauperes de platea Monialium“ (Mendl 1935, 54, 95-97, 174; Vičar 1965, 262). Tyto poměry, sledovatelné v archivních pramenech, však ostře kontrastují s archeologickou nálezovou situací ze 13. století, kdy je v odpadních jímkách deponováno luxusní zboží (sklo, značný počet mincí atd.), a musíme tedy uvažovat, že tehdy byla sociální úroveň obyvatel na vyšší úrovni než v mladších obdobích zachycených písemnými prameny. Některá městiště lze identifikovat až na základě situace z r. 1645 spolu se zápisy pamětní knihy z let 1343-1376 (1379) a sledu rejstř́íků z poloviny 14. století (Vičar 1965, 262; Flodr (ed.) 2005). Významným vodítkem při rekonstrukci nám však zůstává i stabilní katastr z roku 1825. Na základě těchto pramenů předpokládáme, že do prostranství staveniště zasahovala tři městiště situovaná do ulice Panenské. Jednalo se o parcely domů Panenská 3 a 5 a částečně i o dům Panenská 7. K vytyčení středověké parcelní hranice napomáhá mimo jiné také sledování rozmístění suterénů stř̌edověkých

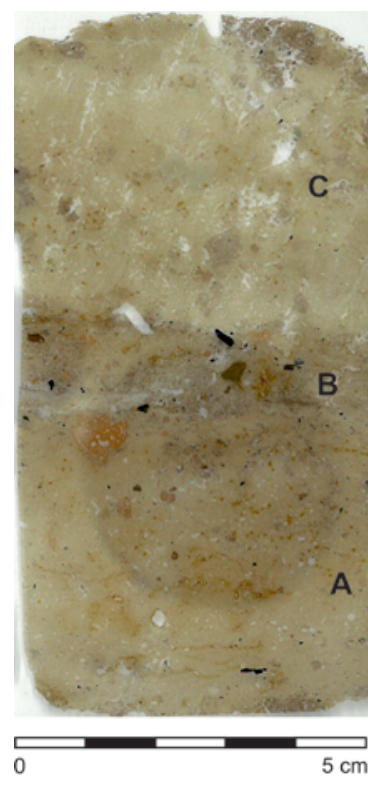

Obr. 15. Základní mikrostratigrafické členění podlahového setu vzorku 75/08/07 z lokality Orlí 19 s př́kladem typické mikrostruktury; a - horizontální póry vzniklé v důsledku mechanického tlaku z nadloží, druhotně impregnované roztoky bohatými na železo a fosfáty (pasivní vrstva $A$ ); b - náteky až impregnace na vnitřních okrajích pórů (označeno modře) aktivní vrstvy B; c - iluviační horizonty v rámci aktivní vrstvy $B$. Zbytek matrix je ovlivněn deplecí; $d$ - fragment vápnitého tmelu v pasivní vrstvě $C$. Všechny mikrofotografie byly pořízeny v procházejícím světle (PPL). Autor L. Lisá.

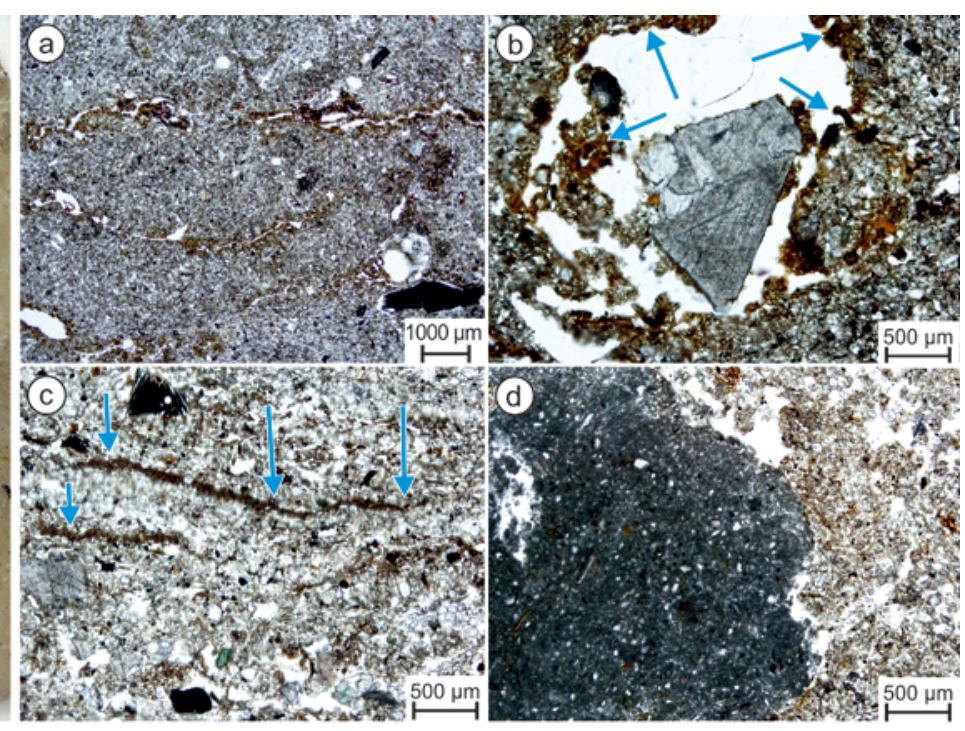

Fig. 15. Basic microstratigraphical division of the floor set documented in sample 75/08/07 from the Orli 19 site with examples of the most common micromorphological features; a - horizontal pores as a result of the press from above; these pores are secondarily impregnated by Fe and $P$ rich solutions (passive layer $A$ ); $b$ - coatings and hypo-coatings in the inner parts of the pores (highlighted in blue) of active layer B; $C$ - illuvial horizons of active layer $B$; the rest of the matrix is influenced by depletion; $d$ - a fragment of calcareous coating inside passive layer $C$. All microphotographs were taken in plane polarised light (PPL). Author L. Lisá. 
domů a orientace jejich vstupů. Komplexní topografická situace je v současnosti předmětem zpracování a není zcela jednoznačná. Vymezení hranic, resp. stanovení šíře městišt', má několik možných variant, nicméně všechny suterény respektují základní orientaci pozdějších parcelních hranic. U nadzemních staveb je tato otázka samozřejmě složitější a bude osvětlena až po komplexním zpracování celého výzkumu.

\subsubsection{Vzorek 1 - suterén 9 (obr. 21: 1)}

Vzorek byl odebrán z podlahové úrovně suterénu 9. Tvořila ji vrstvička šedé plastické hlíny s nahodilým výskytem uhlíků a zlomků vypálené mazanice. Na ní ležely zásypy suterénu. Vytvořen byl výkopem, který měl původně obdélný nebo čtvercový půdorys o rozměrech $8,20 \times>6 \mathrm{~m}$. Dokumentovaná hloubka činila 2,60 m. Stěny byly původně zajištěny dřevěnou konstrukcí, která byla osazena do trámů, horizontálně uložených v mělkých žlábcích podél stěn výkopu. Jimi vymezený prostor měl rozměry $6,70 \times 5,60 \mathrm{~m}$. Vstup do suterénu zprostředkovávala vstupní šíje vytvořená výkopem o šíŕce $2,20 \mathrm{~m}$. Suterén se nacházel ve střední části př́slušné parcely. Lze ho datovat do období 2. poloviny 13. až 1. poloviny 14. století.

$\mathrm{V}$ rámci vzorku 1 , který je tvořen dvěma na sebe navazujícími výbrusy, byly vyčleněny tř̀ hlavní subfacie označené jako A, B, C (obr. 16). Detailní mikromorfologické popisy studovaných vzorků jsou uvedeny v tab. 1. Interpretace: v rámci vzorku lze obecně vyčlenit dvě pasivní a jednu aktivní vrstvu. Spodní pasivní vrstva (subfacie A) je tvořena jen mírně kontaminovanou redeponovanou spraší ve svrchní části silně ovlivněnou tlakem z nadloží. Aktivní vrstva je značně nehomogenní, vykazuje známky opakovaného usměrňování a zároveň má množství postsedimentárních struktur typických pro pronikající roztoky. Jde tedy pravděpodobně o podlahový horizont udržovaný mokrým zametáním nebo intenzivním popocházením s fázemi, kdy v suterénu stála voda. V nejsvrchnější části jsou půdní krusty typické pro stagnující vodu. Pasivní vrstva označená jako subfacie $\mathrm{C}$ je tvořena redeponovanou spraší silně kontaminovanou antropogenními prvky (nejen fragmenty hornin, ale především rozkládajícím se dřevem), a je pravděpodobné, že jde o destrukci nějakého stavebního prvku.

\subsubsection{Vzorek 2 - nadzemní stavba (obr. 21: 2)}

Vzorek byl odebrán z podlahových úrovní nadzemní části zřejmě dřevohliněné stavby, která nestávala při uliční čáře. Uloženy byly na vrstvě přenesené spraše (s.j. 3104=3111), která měla zřejmě vyrovnat depresi terénu, způsobenou především proklesem zásypů staršího suterénu. Její povrch překryla tenká hnědošedá vrstvička (s.j. 3129), patrně vzniklá nášlapem, následovala (sanační?) vrstva okrové plastické hlíny (s.j. 3128). Povrch opět překryla tenká šedá vrstvička (s.j. 3127). Dále byla podlaha navýšena prostřednictvím uloženiny s.j. 2378 sestávající především z okrové plastické hlíny. Na ní byla přítomna výrazně popelovitá vrstvička s.j. 2377, následovala podlahová vrstvička s.j. 2374, tvořená především šedou plastickou hlínou. Překryla ji vrstva šedookrové plastické hlíny (s.j. 2375), snad navýšení podlahy či planýrka konstrukce stavby. Situaci lze zasadit do období 2. poloviny 13. až 14 . století.

$\mathrm{V}$ rámci vzorku 2 bylo vyčleněno celkem osm mikrofacií (obr. 17). Detailní mikromorfologické popisy studovaných vzorků jsou uvedeny v tab. 1. Interpretace vzorku je následující: studovaná stratigrafie zahrnuje několik pasivních a aktivních vrstev. Jako pasivní podlahové vrstvy mohou být označeny subfacie A, C, E a H. Jako aktivní podlahové vrstvy mohou být označeny subfacie B, D, F a G, přičemž subfacie F a G jsou silně mechanicky postiženy z důvodu požáru. Většina pasivních vrstev je tvořena redeponovanou spraší, minimálně kontaminovanou artefakty. Subfacie B vykazuje minimální známky kompakce. Ta je

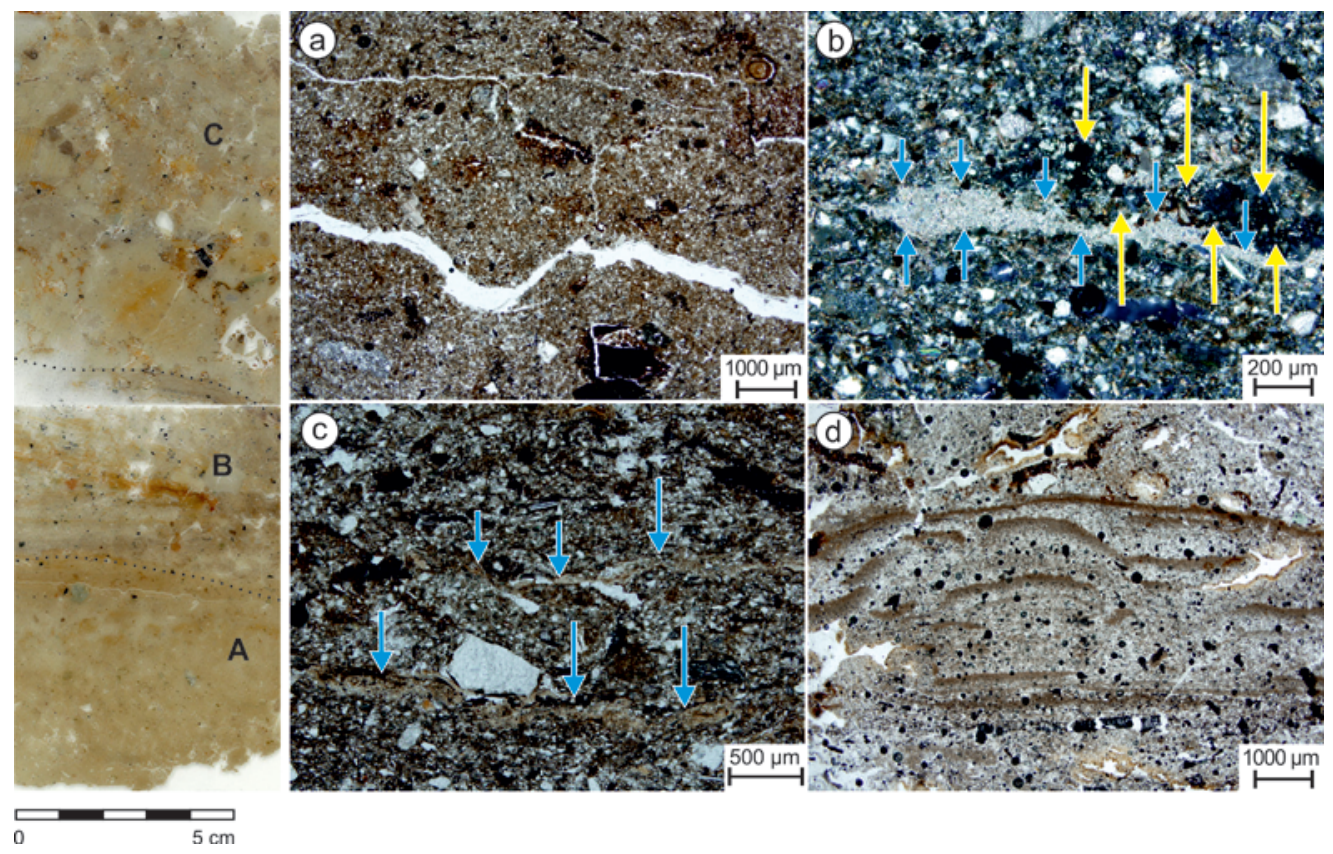

Obr. 16. Základní mikrostratigrafické členění podlahového setu vzorku 1 z lokality Panenská s př́kladem typické mikrostruktury; a - horizontální pukliny ve svrchní části subfacie A indikující mechanický tlak z nadloží; b - proplástky v rámci facie B. Žlutě jsou označeny proplástky bohaté na fosfáty, modře potom proplástek mikritického karbonátu; c - proplástky fosfátů (modře označeno) často v souvislosti s akumulacemi uhlíků; $\mathrm{d}$ - tzv. půdní krusty indikující vysychání v nejsvrchnější části facie B. Mikrofotografie a, c, d byly pořízeny v procházejícím světle (PPL), mikrofotografie b potom ve světle procházejícím zkř́iženými nikoly (XPL). Autor L. Lisá.
Fig. 16. Basic microstratigraphical division of the floor set documented in sample 1 from the Panenská site with examples of the most common micromorphological features; a - horizontal pores in the upper part of subfacie A indicating mechanical pressure from above; $b$ - lenses within subfacie $B$; those rich in phosphates are highlighted in yellow; the micritic carbonate lens is highlighted in blue; $c$ - lenses rich in phosphates (highlighted in blue) are often in association with the charcoal; $d$-so-called soil crusts indicate drying of the uppermost layer marked as B. Microphotographs a, c, $d$ were taken in plane polarised light (PPL), microphotograph b was taken in cross polarised light (XPL). Author L. Lisá. 

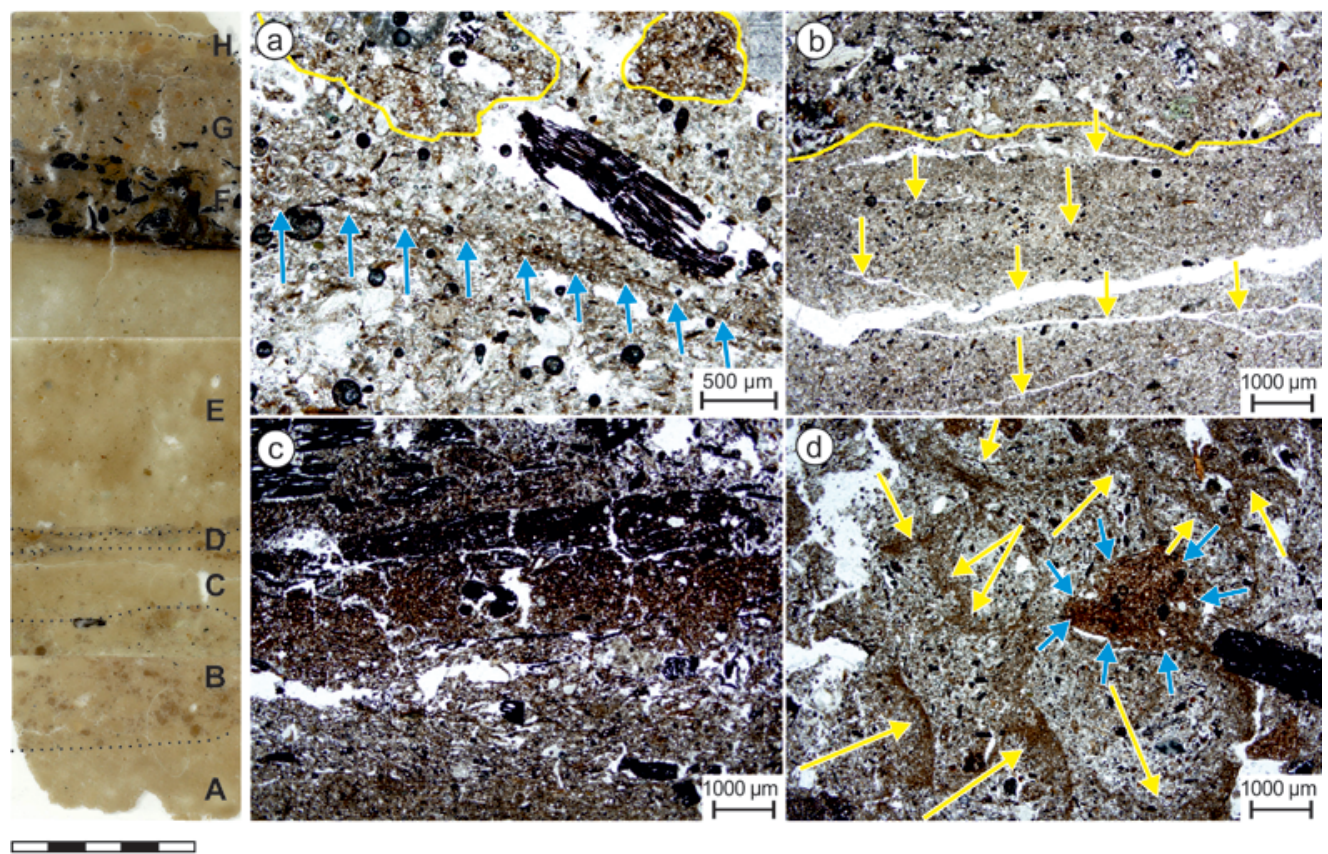

0

$5 \mathrm{~cm}$

Obr. 17. Základní mikrostratigrafické členění podlahového setu vzorku 2 z lokality Panenská s př́kladem typické mikrostruktury; a - subfacie B je zrnitostně relativně vytříděná, avšak složená z množství půdních agregátů (označeno žlutě) smíchaných s agregáty redeponované spraše; nevykazuje žádné horizontální usměrnění kromě jednoho místa (označeno modře); b - horizontální póry v subfacii C (označeno žlutě); c - v rámci bazální části subfacie $\mathrm{F}$ je znatelný přechod do podlož způsobený propálením; d - propálené klasty matrix v subfacii G (označeno modře); stopy po lezení (směr lezení označen žlutě). Všechny mikrofotografie byly pořízeny v procházejícím světle (PPL). Autor L. Lisá.
Fig. 17. Basic microstratigraphical division of the floor set documented in sample 2 from the Panenská site with examples of the most common micromorphological features; a - subfacie $B$ is well sorted but composed of single soil aggregates (highlighted in yellow) mixed with the loess aggregates; there is no horizontal orientation in the matrix except for one part (highlighted in blue); b-horizontal pores inside subfacie $C$ (highlighted in yellow); $c$ - the basal part of subfacie $F$ is highlighted by burning; $d$-burned soil clasts in subfacie $G$ (highlighted in blue) as well as passage features (the direction of passing in the matrix is highlighted in yellow). All microphotographs were taken in plane polarised light (PPL). Author L. Lisá.
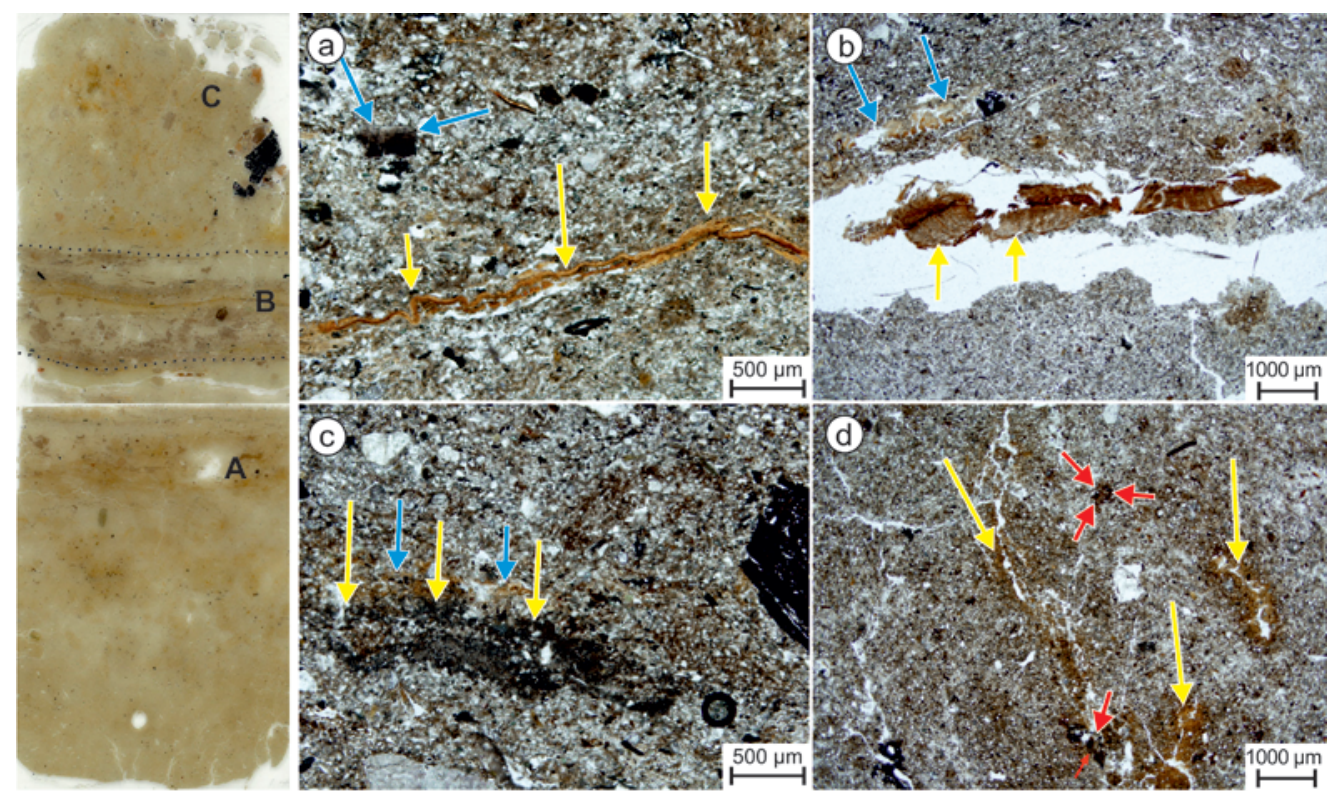

0

$5 \mathrm{~cm}$

Obr. 18. Základní mikrostratigrafické členění podlahového setu vzorku 3 z lokality Panenská s př́kladem typické mikrostruktury; a - fosfatické laminy v subfacii B (označeno žlutě) a skořápka vejce (označeno modře); $b$ - fragmenty dřeva v subfacii B (označeno žlutě) a jílovité náteky (označeno modře); c - lokální impregnace mikritickým karbonátem v subfacii $\mathrm{B}$, místy s př́tomností mikrouhlíků indikujících popel jako jeho zdroj (označeno žlutě); karbonáty představujî́ změnu $\mathrm{pH}$, na což reaguje zpomalení posunu jílových minerálů (označeno modře); $\mathrm{d}$ - hlavní pedostrukturní znaky subfacie $\mathrm{C}$ jsou náteky fosfátů na vnitřní straně vertikálních pórů (označeno žlutě) a výskyt malých Fe/Mn konkrecí (označeno červeně). Všechny mikrofotografie byly pořízeny v procházejícím světle (PPL). Autor L. Lisá.
Fig. 18. Basic microstratigraphical division of the floor set documented in sample 3 from the Panenská site with examples of the most common micromorphological features; a - phosphatic laminae in subfacie $B$ (highlighted in yellow) and egg shell (highlighted in blue); $b$ - wood fragments in subfacie $B$ (highlighted in yellow) and clay coatings (highlighted in blue); $\mathrm{C}$ - local impregnation by micritic carbonate in subfacie $B$, locally connected with the presence of microcharcoal indicating the ash as its source (highlighted in yellow); carbonates change $\mathrm{pH}$ of sediments and the clay minerals react by the slowing of its movement (highlighted in blue); $d$ - the main pedofeatures of subfacie $C$ are $P$ rich coatings in inner parts of the vertical pores (highlighted in yellow) and the presence of small Fe/Mn concretions (highlighted in red). All microphotographs were taken in plane polarised light (PPL). Author L. Lisá. 
viditelná pouze v části vrstvy. Subfacie D vykazuje známky kompakce, která se promítá i do nejsvrchnější části podložní facie C. Subfacie D obsahuje množství uhlíků, kostí, spálených kostí, avšak je zde patrná absence usměrnění a je pravděpodobné, že vznikla relativně rychle. Subfacie $\mathrm{F}$ je typická množstvím uhlíků. Vykazuje známky horizontálního usměrnění i výraznou bioturbaci. Nebyly pozorovány známky promývání. Ke spálení došlo na místě, což je dobře patrné z mírně propáleného přechodu do podloží, tj. do subfacie E. Vrstva obsahuje strukturní prvky typické pro sídlištní/kuchyňský odpad a je ve svrchní části silně bioturbována.

\subsubsection{Vzorek 3 - suterén 7 (obr. 21: 3)}

Vzorek byl odebrán z podlahové úrovně suterénu 7. Při výzkumu byla rozdělena na tři základní jednotky, celková mocnost dosahovala $10 \mathrm{~cm}$. Př́ímo na dně suterénu ležela vrstvička šedé plastické hlíny (s.j. 2135), následovala vrstvička okrové plastické hlíny (s.j. 2134) a dále vrstvička s.j. 2131, která měla obdobný charakter jako s.j. 2135. Na ní již byly uloženy zásypy suterénu. Ten byl utvořen výkopem, který měl přibližně obdélný půdorys o rozměrech 4,50 × $4 \mathrm{~m}$. Hloubka výkopu od povrchu půdního typu činila $2,20 \mathrm{~m}$. Stěny byly původně zajištěny dřevěnou konstrukcí, na jejímž stabilizování se podílely svislé konstrukční prvky, zapuštěné do sloupových a kůlových jamek. Vstup do suterénu zprostředkovávala vstupní šíje vytvořená výkopem o šířce $1,20 \mathrm{~m}$. Suterén se nacházel ve střední části příslušné parcely. Lze ho datovat do období 2 . poloviny 13. až 1 . poloviny 14. století.

V rámci vzorku 3 byly vyčleněny celkem tři subfacie (obr. 18). Detailní mikromorfologický popis je v tab. 1. Interpretace tohoto vzorku je následující: pasivní vrstvy podlahového sendviče jsou tvořeny subfaciemi A a C. Jsou tvořeny mírně ovlivněnou spraší. Aktivní vrstva, tj. subfacie B, vznikala díky dlouhodobému tlaku na její povrch. Působení tlaku se odráží vznikem horizontálních pórů v podloží, což je dobře viditelné ve vrchní části podložní pasivní vrstvy, tj. subfacie $\mathrm{A}$, ale především v samotné, relativně mocné aktivní vrstvě. Samotná aktivní vrstva obsahuje usměrněnou matrix, ale také množství iluviačních náteků. Jednotlivé laminky mají různý původ - karbonátové jsou pravděpodobně redeponovaný popel, fosfatické pocházejí z rozkladu kostí. Vznik iluviačních náteků reflektuje př́tomnost vody. S tím souvisí i výskyt $\mathrm{Fe} / \mathrm{Mn}$ nodulí ve subfacii C, kterou lze interpretovat jako destrukci stavebního prvku, př́ípadně další pasivní vrstvu.

\subsubsection{Vzorek 4 - suterén 9}

Chybou v inventarizaci se nepodařilo vzorek spojit s konkrétní nálezovou situací. Velmi pravděpodobně pochází z podlahové úrovně některého ze suterénů dřevohliněných staveb. Není vyloučeno, že jde o další vzorek ze suterénu 9 (viz vzorek 1).

$\mathrm{V}$ rámci vzorku 4 byly vyčleněny celkem tři mikrofacie, označené jako A, B a C (obr. 19). Detailní mikromorfologický popis je v tab. 1. Interpretace podlahového setu je následující: subfacie A reprezentuje klasickou pasivní vrstvu tvořenou mírně ovlivněnou spraší. Na ni s ostrou hranicí nasedá vrstvička mikrouhlíků a následuje depozice usměrněné matrix. Pod bazální vrstvičkou uhlíků byla detekována vrstvička mikritického karbonátu z degradovaného popela. Tento typ vrstvy se minimálně ještě jednou v aktivní vrstvě opakuje. Jejich vznik pravděpodobně souvisí posunem karbonátů ze závěrečné fáze fungování aktivní vrstvy. Tam je pedogenní krusta, která vznikla jako krusta na povrchu kaluže, tzn. indikuje sloupec vody. Facie C je destrukce stavebního prvku.

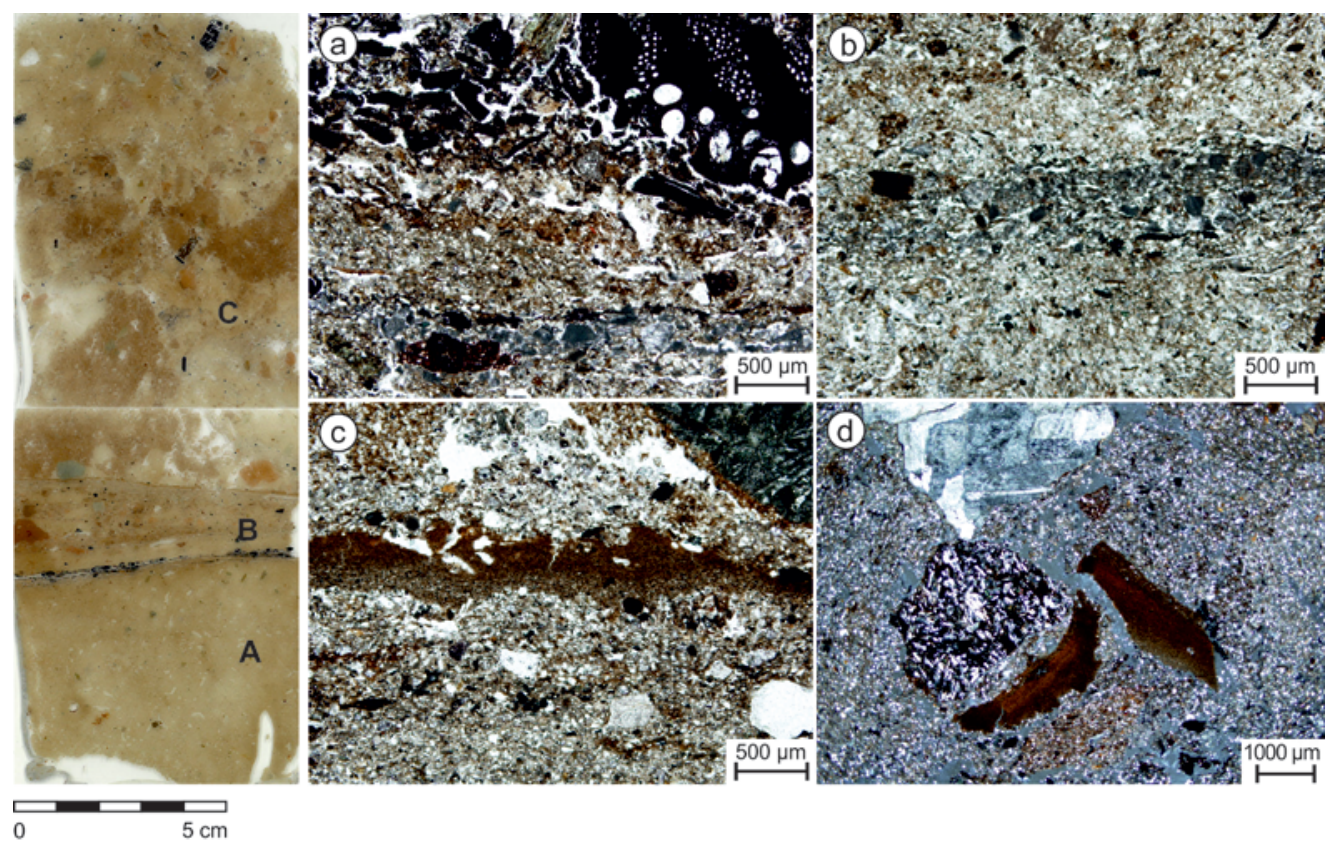

Obr. 19. Základní mikrostratigrafické členění podlahového setu vzorku 4 z lokality Panenská s př́kladem typické mikrostruktury; a - tenká vrstvička spálené organické hmoty a mikritického karbonátu z degradovaného popela, iluviální náteky; b - vrstvička mikritického karbonátu z degradovaného popela se objevuje znovu cca v polovině aktivní vrstvy B; c - celá aktivní vrstva je zakončena půdní krustou (prachovitá lamina); d - klasty redeponovaných prachovitých náteků v rámci subfacie $C$. Mikrofotografie $a, b, c$ byly pořízeny v procházejícím světle (PPL), mikrofotografie d byla pořízena ve světle procházejícím zkř́ženými nikoly (XPL). Autor L. Lisá.
Fig. 19. Basic microstratigraphical division of the floor set documented in sample 4 from the Panenská site with examples of the most common micromorphological features; a - thin layer of burnt organic matter and micritic carbonate from the degraded ash, illuvial coatings; $b$ - microlayer of micritic carbonate as a result of ash degradation appears approximately in the middle of subfacie $B ; C$ - the active layer is covered by the soil crust (silty laminae); $d$ - clasts of redeposited silty coatings of subfacie C. Microphotographs a, b, c were taken in plane polarised light (PPL), microphotograph d was taken in cross polarised light (XPL). Author L. Lisá. 
1 - Bašty 2-4, s.s.j. 57 , řez R20

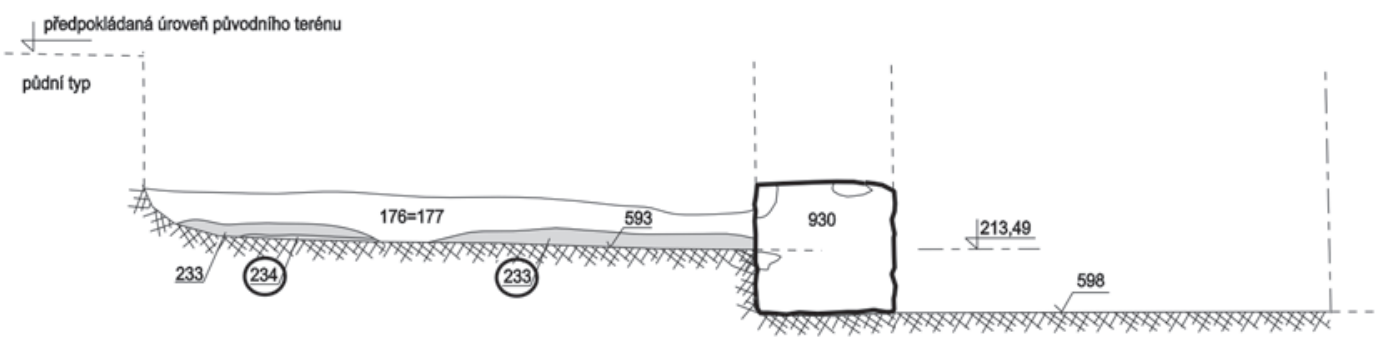

2 - Bašty 2-4, s.s.j. 57 , řez R21

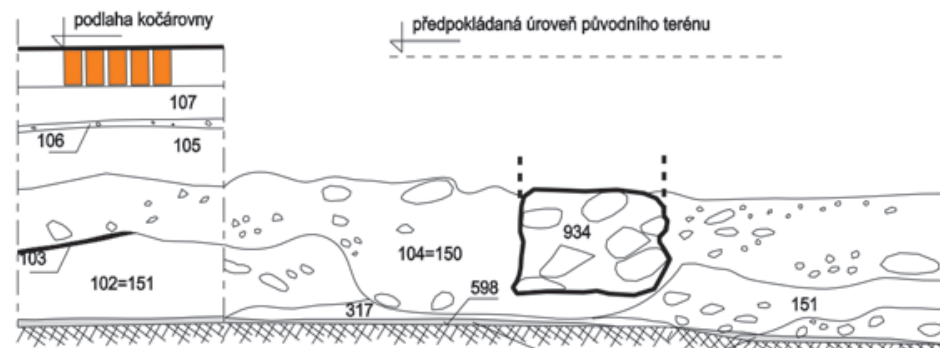

(318

3-Biskupská 7, vzorek č. 2, řez P10

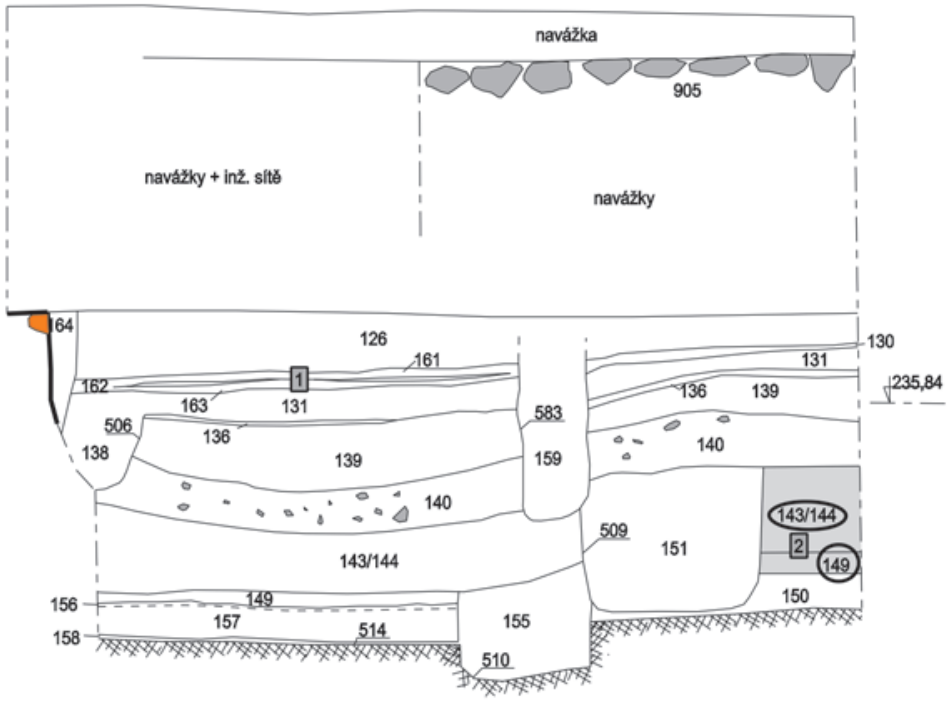

4 - Biskupská 7, vzorek č. 4, řez P11

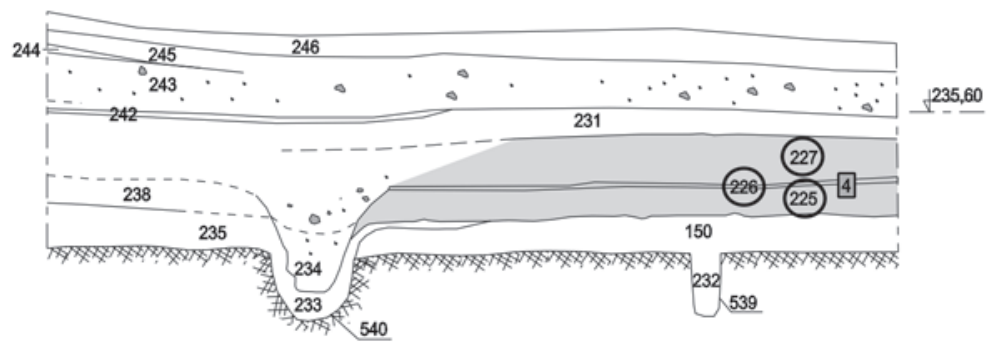

5 - Biskupská 7, vzorek s.j. 266, 249, řez P16

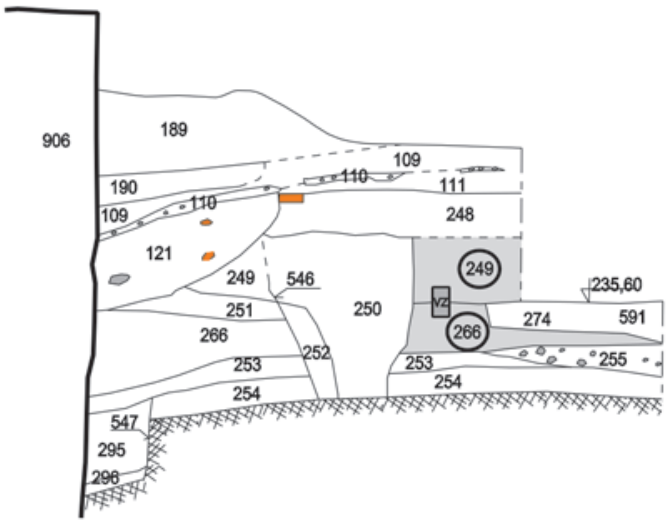

6 - Biskupská 7, vzorek s. j. 283-284, řez 15

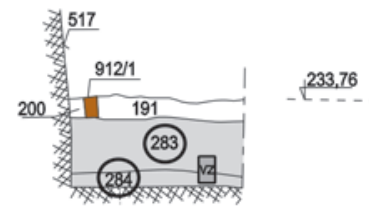


Panenská 1, vzorek 1, řez P19

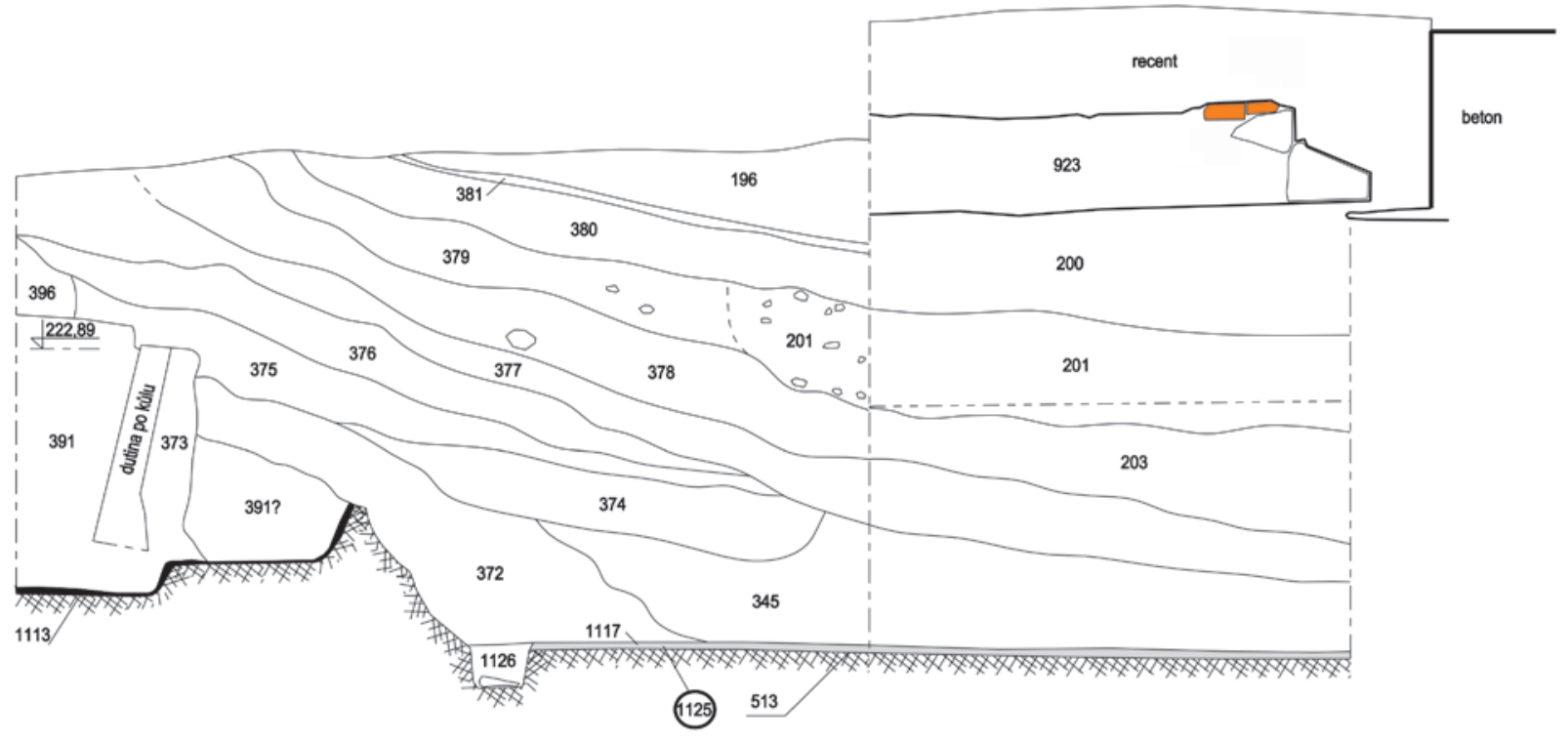

Panenská 1, vzorek 2, řez P101 až 103

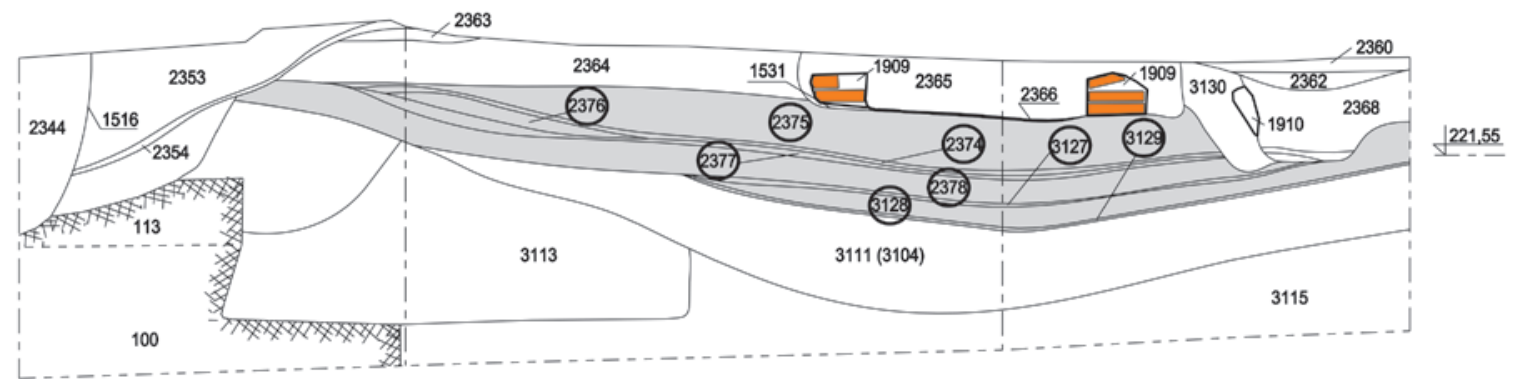

Panenská 1, vzorek 3, řez P70

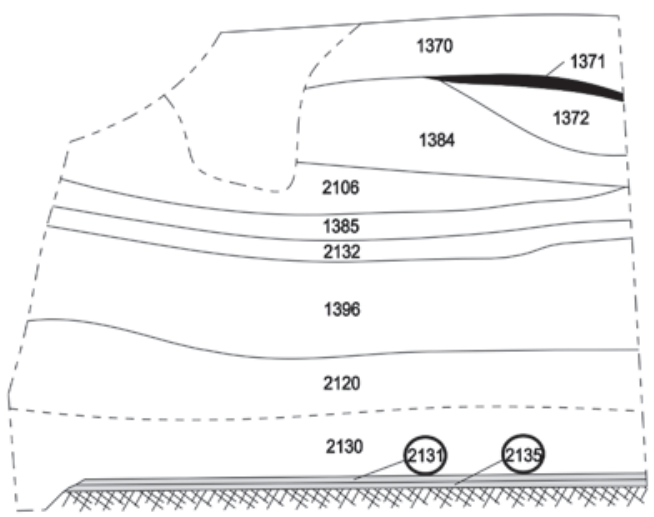

Orli 19, vzorky 75/08/05 až 07, řez P5

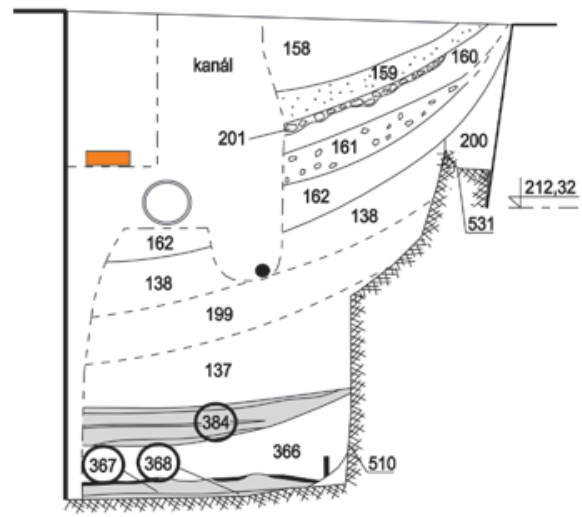




\begin{tabular}{|c|c|c|c|c|c|c|c|}
\hline Vzorek & Subf. & $\mathbf{M}$ & Porozita & Základní hmota & $\begin{array}{l}\text { Organická } \\
\text { a organominerální část }\end{array}$ & Pedostrukturní prvky & Poznámky \\
\hline Bašty A20/1 & A & $\mathrm{Ch}$ & $\begin{array}{l}\text { Kanálky***; } \\
\text { zaoblené dutiny** }\end{array}$ & $\begin{array}{l}\text { Qzr, Fls, slída, sparitický } \\
\text { karbonát, opákní } \\
\text { minerály; barva světle } \\
\text { hnědá; Bf krystalický }\end{array}$ & $\begin{array}{l}\text { Rozložená OM hnědá ve } \\
\text { formě tečkování *** }\end{array}$ & $\begin{array}{l}\text { Impregnační náteky } \\
\text { CaCO3** na pórech po } \\
\text { kořenech; impregnace } \\
\text { fosfáty *; stopy po } \\
\text { lezení**; exkrementy } \\
\text { mikrofauny * }\end{array}$ & Přechod do nadloží je ostrý \\
\hline Bašty A20/1 & B & C & $\begin{array}{l}\text { Dutiny } \\
\text { nepravidelného } \\
\text { tvaru **; trhliny*; } \\
\text { horizontální } \\
\text { póry**; kanálky* }\end{array}$ & $\begin{array}{l}\text { Qzr, Fls, slída, sparitický } \\
\text { a mikritický karbonát, } \\
\text { opákní minerály, } \\
\text { fragmenty hornin } \\
\text { metabaziové zóny; } \\
\text { variabilní barva matrix; } \\
\text { Bf krystalický }\end{array}$ & $\begin{array}{l}\text { Částečně rozložená } \\
\text { a rozložená OM****; } \\
\text { uhlíky**; artikulované } \\
\text { fytolity***; fytolity } \\
\text { rozptýlené v matrix*; } \\
\text { fragmenty kostí } \\
\text { a spálených kostî** }\end{array}$ & $\begin{array}{l}\text { Stopy po lezení****; } \\
\text { exkrementy } \\
\text { mikrofauny**; } \\
\text { impregnace fosfáty*** }\end{array}$ & $\begin{array}{l}\text { Viditelná přítomnost } \\
\text { kuchyňského odpadu }\end{array}$ \\
\hline Bašty A20/2 & A & $\mathrm{Ch}$ & $\begin{array}{l}\text { Kanálky***; } \\
\text { zaoblené dutiny** }\end{array}$ & $\begin{array}{l}\text { Qzr, Fls, slída, sparitický } \\
\text { karbonát, opákní } \\
\text { minerály; barva světle } \\
\text { hnědá; Bf krystalický }\end{array}$ & $\begin{array}{l}\text { Rozložená OM ve formě } \\
\text { tečkování* }\end{array}$ & $\begin{array}{l}\text { Impregnační náteky } \\
\text { CaCO3**; P náteky na } \\
\text { kanálcích* }\end{array}$ & $\begin{array}{l}\text { Homogenní vytříděný } \\
\text { sediment - spraš; přechod } \\
\text { do nadloží je ostrý }\end{array}$ \\
\hline Bašty A20/2 & B & G & $\begin{array}{l}\text { Meziagregátové } \\
\text { póry***; praskliny } \\
\text { v rámci agregátů** }\end{array}$ & $\begin{array}{l}\text { Qzr, Fls, slída, opákní } \\
\text { minerály, polozaoblené } \\
\text { klasty metabazitů; barva } \\
\text { matrix tmavě hnědá; } \\
\text { Bf krystalický }\end{array}$ & $\begin{array}{l}\text { Rozložená černá i hnědá } \\
\text { OM****; mikrouhlíky***; } \\
\text { neartikulované fytolity** }\end{array}$ & $\begin{array}{l}\text { Exkrementální } \\
\text { struktury po } \\
\text { mikrofauně } \\
\text { náteky a impregnace } \mathrm{Fe} \\
\text { a } \mathrm{P}^{* * *}\end{array}$ & $\begin{array}{l}\text { Granule jsou ostrohranné } \\
\text { až poloostrohranné }\end{array}$ \\
\hline Bašty A20/2 & C & $\mathrm{P}$ & $\begin{array}{l}\text { Horizontální } \\
\text { póry****; } \\
\text { větší dutiny** }\end{array}$ & $\begin{array}{l}\text { Qzr, Fls, slída, opákní } \\
\text { minerály, sparitický } \\
\text { a mikritický karbonát; } \\
\text { barva šedohnědá; } \\
\text { Bf krystalický }\end{array}$ & $\begin{array}{l}\text { Rozložená hnědá } \mathrm{OH}^{* * * *} \text {; } \\
\text { uhlíky a mikrouhlíky***; } \\
\text { artikulované fytolity***** }\end{array}$ & $\begin{array}{l}\text { Bioturbace }{ }^{* *} ; \text { lokální } \\
\text { akumulace fosfátů* }\end{array}$ & $\begin{array}{l}\text { Mikrostruktura je } \\
\text { predisponovaná } \\
\text { horizontálně uloženými } \\
\text { akumulacemi } \\
\text { artikulovaných fytolitů }\end{array}$ \\
\hline Bašty A20/2 & $\mathrm{D}$ & C & $\begin{array}{l}\text { Dutiny } \\
\text { nepravidelného } \\
\text { tvaru***; } \\
\text { trhliny**; } \\
\text { horizontální } \\
\text { póry**; kanálky** }\end{array}$ & $\begin{array}{l}\text { Qzr, Fls, slída, opákní } \\
\text { minerály, sparitický } \\
\text { a mikritický karbonát; } \\
\text { barva matrix variabilní - } \\
\text { světle hnědá, hnědošedá, } \\
\text { hnědooranžová; } \\
\text { Bf krystalický }\end{array}$ & $\begin{array}{l}\text { Částečně rozložená } \\
\text { a rozložená OH***; uhlíky } \\
\text { a mikrouhlíky**; místy } \\
\text { horizontálně uložené } \\
\text { artikulované fytolity**; } \\
\text { fytolity rozptýlené } \\
\text { v matrix** }\end{array}$ & $\begin{array}{l}\text { Stopy po lezení****; } \\
\text { exkrementy } \\
\text { mikrofauny***; } \\
\text { impregnace fosfáty**}\end{array}$ & Silně nehomogenní materiál \\
\hline Bašty A20/4 & A & $\mathrm{Ch}$ & $\begin{array}{l}\text { Kanálky***; } \\
\text { zaoblené dutiny** }\end{array}$ & $\begin{array}{l}\text { Qzr, Fls, slída, sparitický } \\
\text { karbonát; barva světle } \\
\text { hnědá; Bf krystalický }\end{array}$ & $\begin{array}{l}\text { Rozložená hnědá OM ve } \\
\text { formě tečkování** }\end{array}$ & $\begin{array}{l}\text { Impregnační náteky na } \\
\text { okrajích pórů po } \\
\text { kořenové bioturbaci** }\end{array}$ & $\begin{array}{l}\text { Homogenní vytř́íděný } \\
\text { sediment (spraš); přechod } \\
\text { do nadloží je ostrý }\end{array}$ \\
\hline Bašty A20/4 & B & C & $\begin{array}{l}\text { Horizontální } \\
\text { póry***; } \\
\text { větší dutiny } \\
\text { nespecifického } \\
\text { tvaru** }\end{array}$ & $\begin{array}{l}\text { Qzr, Fls, slída, časté } \\
\text { úlomky metabazitů, } \\
\text { propálené agregáty } \\
\text { jemnozrnné matrix; světle } \\
\text { hnědá barva; Bf krystalický }\end{array}$ & $\begin{array}{l}\text { Rozložená hnědá } \mathrm{OH}^{* * *} \text {; } \\
\text { uhlíky**; } \\
\text { mikrouhlíky*****; } \\
\text { rozptýlené fytolity**; } \\
\text { fragmenty spálených } \\
\text { kostí*; vaječné skořápky* }\end{array}$ & $\begin{array}{l}\text { Bioturbace }{ }^{* *} \\
\text { exkrementy } \\
\text { mikrofauny* }\end{array}$ & $\begin{array}{l}\text { Materiál vrstvy je } \\
\text { nevytř́íděný, výskyt } \\
2 \text { horizontů výrazně } \\
\text { nabohacených na uhlíky } \\
\text { a mikrouhlíky }\end{array}$ \\
\hline Bašty A20/4 & C & $\mathrm{Ch}$ & $\begin{array}{l}\text { Kanálky**; } \\
\text { zaoblené dutiny** }\end{array}$ & $\begin{array}{l}\text { Qzr, Fls, slída, opákní } \\
\text { minerály, úlomky } \\
\text { metabazitů, propálené } \\
\text { agregáty jemnozrnné } \\
\text { matrix; světle hnědá } \\
\text { barva; Bf krystalický }\end{array}$ & $\begin{array}{l}\text { Rozložená hnědá } \mathrm{OH}^{* *} \text {; } \\
\text { uhlíky a mikrouhlíky } \\
\text { rozptýlené v matrix**; } \\
\text { skořápky a fragmenty } \\
\text { kostít }\end{array}$ & $\begin{array}{l}\text { Občasné impregnační } \\
\text { náteky CaCO3 na } \\
\text { okrajích pórů po } \\
\text { kořenové bioturbaci** }\end{array}$ & \\
\hline Bašty A20/5 & A & $\mathrm{Ch}$ & $\begin{array}{l}\text { Kanálky**; } \\
\text { zaoblené dutiny*** }\end{array}$ & $\begin{array}{l}\text { Qzr, Fls, slída, opákní } \\
\text { minerály; světle hnědá } \\
\text { barva; Bf krystalický }\end{array}$ & $\begin{array}{l}\text { Rozložená hnědá OH ve } \\
\text { formě tečkování* }\end{array}$ & $\begin{array}{l}\text { Občasné impregnační } \\
\text { náteky CaCO3 na } \\
\text { okrajích pórů po } \\
\text { kořenové bioturbaci* }\end{array}$ & $\begin{array}{l}\text { Homogenní vytříděný } \\
\text { sediment - spraš }\end{array}$ \\
\hline Bašty A20/5 & B & $\mathrm{C}$ & $\begin{array}{l}\text { Horizontální } \\
\text { póry**; větší } \\
\text { dutiny } \\
\text { nespecifického } \\
\text { tvaru* }\end{array}$ & $\begin{array}{l}\text { Qzr, Fls, slída, opákní } \\
\text { minerály, úlomky } \\
\text { metabazitů, propálené } \\
\text { agregáty jemnozrnné } \\
\text { matrix; světle hnědá } \\
\text { barva; Bf krystalický }\end{array}$ & $\begin{array}{l}\text { Rozložená OH***; } \\
\text { uhlíky a mikrouhlíky****; } \\
\text { rozptýlené fytolity*; } \\
\text { fragmenty spálených } \\
\text { kostí*; vaječná skoŕápka+ }\end{array}$ & $\begin{array}{l}\text { Bioturbace }{ }^{* *} \\
\text { exkrementy } \\
\text { mikrofauny* }\end{array}$ & $\begin{array}{l}\text { Matrix nevytříděná, } \\
\text { usměrnění pod úhlem }\end{array}$ \\
\hline Biskupská 1 & A & $\operatorname{Pr}$ & $\begin{array}{l}\text { Horizontální } \\
\text { a vertikální } \\
\text { praskliny**; } \\
\text { kanálky+ }\end{array}$ & $\begin{array}{l}\text { Qzr, Fls, slída, opákní } \\
\text { minerály, úlomky } \\
\text { metabazitů; světle hnědá } \\
\text { barva; Bf krystalický }\end{array}$ & $\begin{array}{l}\text { OH rozložená hnědá ve } \\
\text { formě tečkování*; } \\
\text { mikoruhlíky* }\end{array}$ & $\begin{array}{l}\text { Bioturbace*; prachovité } \\
\text { náteky na vnitřních } \\
\text { stranách pórů*** }\end{array}$ & $\begin{array}{l}\text { Matrix je středně vytříděná, } \\
\text { místy má známky } \\
\text { usměrnění }\end{array}$ \\
\hline Biskupská 1 & B & C & $\begin{array}{l}\text { Horizontální } \\
\text { pukliny**; } \\
\text { meziagregátové } \\
\text { póry***; kanálky* }\end{array}$ & $\begin{array}{l}\text { Qzr, Fls, slída, opákní } \\
\text { minerály, úlomky } \\
\text { metabazitů, propálené } \\
\text { agregáty jemnozrnné } \\
\text { matrix; hnědá barva; } \\
\text { Bf krystalický }\end{array}$ & $\begin{array}{l}\text { Částečně rozložená } \\
\text { a rozložená hnědá OH***; } \\
\text { artikulované fytolity nebo } \\
\text { fytolity rozmístěnými } \\
\text { v matrix }{ }^{* * * ;} \text { mikrouhlíky } \\
\text { a uhlíky****; propálené } \\
\text { kosti a zbytky skořápek }{ }^{* *}\end{array}$ & $\begin{array}{l}\text { Exkrementy } \\
\text { mikrofauny***; stopy } \\
\text { po lezení**; prachovité } \\
\text { náteky** }\end{array}$ & $\begin{array}{l}\text { Nehomogenní s náznaky } \\
\text { vnitřního usměrnění. } \\
\text { Přechod z podloží je tvořen } \\
\text { tenkou vrstvičkou } \\
\text { propálené průběžné OH }\end{array}$ \\
\hline
\end{tabular}




\begin{tabular}{|c|c|c|c|c|c|c|c|}
\hline Vzorek & Subf. & $\mathbf{M}$ & Porozita & Základní hmota & $\begin{array}{l}\text { Organická } \\
\text { a organominerální část }\end{array}$ & Pedostrukturní prvky & Poznámky \\
\hline Biskupská 1 & B & $\mathrm{C}$ & $\begin{array}{l}\text { Horizontální } \\
\text { a vertikální } \\
\text { pukliny**; } \\
\text { kanálky+ }\end{array}$ & $\begin{array}{l}\text { Qzr, Fls, slída, opákní } \\
\text { minerály, úlomky } \\
\text { metabazitů; světle hnědá } \\
\text { barva; Bf krystalický }\end{array}$ & $\begin{array}{l}\text { OH rozložená hnědá ve } \\
\text { formě tečkování*; } \\
\text { mikoruhlíky* }\end{array}$ & $\begin{array}{l}\text { Bioturbace*; prachovité } \\
\text { náteky na vnitřních } \\
\text { stranách pórů*** }\end{array}$ & $\begin{array}{l}\text { Matrix je středně vytříděná, } \\
\text { místy má známky } \\
\text { usměrnění; obsahuje velký } \\
\text { fragment strusky }\end{array}$ \\
\hline Biskupská 2 & A & C & $\begin{array}{l}\text { Meziagregátové } \\
\text { póry***; } \\
\text { praskliny*; } \\
\text { zaoblené dutiny* }\end{array}$ & $\begin{array}{l}\text { Qzr, Fls, slída, opákní } \\
\text { minerály, úlomky } \\
\text { metabazitů, propálené } \\
\text { agregáty jemnozrnné } \\
\text { matrix; světle hnědá } \\
\text { barva; Bf krystalický }\end{array}$ & $\begin{array}{l}\text { Rozložená OH**; uhlíky } \\
\text { a mikrouhlíky*** mimo } \\
\text { agregáty; rozptýlené } \\
\text { fytolity*; fragmenty } \\
\text { spálených kostí*; vaječná } \\
\text { skořápka+ }\end{array}$ & $\begin{array}{l}\text { Stopy po lezení } \\
\text { mikroorganismů**; } \\
\text { místy impregnace } \\
\text { mikritickým } \\
\text { karbonátem* }\end{array}$ & $\begin{array}{l}\text { Značná nehomogenita } \\
\text { v rámci facie, která je } \\
\text { tvořena souborem } \\
\text { poloostrohranných } \\
\text { agregátů půdní matrix, } \\
\text { z nichž některé jsou } \\
\text { propáleny }\end{array}$ \\
\hline Biskupská 2 & B & M & Neobsahuje & $\begin{array}{l}\text { Qzr, Fls, slída, opákní } \\
\text { minerály, úlomky } \\
\text { metabazitů a fragmentů } \\
\text { karbonátových náteků; } \\
\text { světle hnědá barva; } \\
\text { Bf krystalický }\end{array}$ & $\begin{array}{l}\text { Rozložená hnědá OH ve } \\
\text { formě tečkování* }\end{array}$ & $\begin{array}{l}\text { Redeponované } \\
\text { fragmenty } \\
\text { karbonátových náteků+ }\end{array}$ & $\begin{array}{l}\text { Velmi dobré vytř̌ídění, } \\
\text { pravděpodobně přemístěná } \\
\text { spraš }\end{array}$ \\
\hline Biskupská 2 & C & C & $\begin{array}{l}\text { Horizontální } \\
\text { póry**; } \\
\text { meziagregátové } \\
\text { póry***; } \\
\text { praskliny*; } \\
\text { kanálky** }\end{array}$ & $\begin{array}{l}\text { Qzr, Fls, slída, opákní } \\
\text { minerály, úlomky } \\
\text { metabazitů, propálené } \\
\text { agregáty jemnozrnné } \\
\text { matrix; hnědá barva; } \\
\text { Bf krystalický }\end{array}$ & $\begin{array}{l}\text { rozložená } \mathrm{OH}^{* *} \text {; uhlíky } \\
\text { a mikrouhlíky*** mimo } \\
\text { agregáty; rozptýlené } \\
\text { fytolity*; fragmenty } \\
\text { spálených kostí*; vaječná } \\
\text { skořápka+ }\end{array}$ & $\begin{array}{l}\text { Exkrementy } \\
\text { mikrofauny**; stopy } \\
\text { po lezení** }\end{array}$ & $\begin{array}{l}\text { Občasné usměrnění, je však } \\
\text { často tvořen agregáty } \\
\text { půdních klastů } \\
\text { a kuchyňským odpadem. } \\
\text { V nejsvrchnější části } \\
\text { artikulované fytolity } \\
\text { s pravidelným } \\
\text { horizontálním usměrněním }\end{array}$ \\
\hline Biskupská 2 & $\mathrm{D}$ & $\mathrm{M}$ & Neobsahuje & $\begin{array}{l}\text { Qzr, Fls, slída, opákní } \\
\text { minerály, úlomky } \\
\text { metabazitů a fragmentů } \\
\text { karbonátových náteků; } \\
\text { světle hnědá barva; } \\
\text { Bf krystalický }\end{array}$ & $\begin{array}{l}\text { Rozložená hnědá OH ve } \\
\text { formě tečkování* }\end{array}$ & $\begin{array}{l}\text { Redeponované } \\
\text { fragmenty } \\
\text { karbonátových náteků+ }\end{array}$ & $\begin{array}{l}\text { Velmi dobré vytř́ídění, } \\
\text { pravděpodobně přemístěná } \\
\text { spraš; identická s } 2 \mathrm{~B}\end{array}$ \\
\hline Biskupská 4 & A & $\mathrm{D}$ & $\begin{array}{l}\text { Horizontální } \\
\text { protáhlé dutiny** }\end{array}$ & $\begin{array}{l}\text { Qzr, Fls, slída, opákní } \\
\text { minerály; hnědooranžová } \\
\text { barva; Bf krystalický }\end{array}$ & $\begin{array}{l}\text { Č́stečně až plně } \\
\text { rozložená OH (sláma?)***; } \\
\text { artikulované fytolity***; } \\
\text { uhlíky+ }\end{array}$ & $\begin{array}{l}\text { impregnace matrix } \\
\text { hydroxidy železa***; } \\
\text { náteky hydroxidů } \\
\text { železa na okrajích } \\
\text { pórů** }\end{array}$ & $\begin{array}{l}\text { Středně vytříděná matrix } \\
\text { bez výrazného usměrnění }\end{array}$ \\
\hline Biskupská 5 & B & $\mathrm{C}$ & $\begin{array}{l}\text { Meziagregátové } \\
\text { póry*** }\end{array}$ & $\begin{array}{l}\text { Qzr, Fls, slída, opákní } \\
\text { minerály, úlomky } \\
\text { metabazitových hornin, } \\
\text { mikritický karbonát; } \\
\text { barva matrix je variabilní } \\
\text { od oranžové po světle } \\
\text { šedou v závislosti na } \\
\text { postdepozičních změnách; } \\
\text { Bf krystalický }\end{array}$ & $\begin{array}{l}\text { OH je zastoupena ve } \\
\text { formě rozložené hnědé } \\
\text { organické hmoty***; } \\
\text { četných uhlíků } \\
\text { a mikrouhlíků*** často } \\
\text { vázaných na akumulace } \\
\text { mikritického karbonátu } \\
\text { který reprezentuje popel; } \\
\text { množství spálených } \\
\text { a nespálených kostních } \\
\text { úlomků***, na nichž je } \\
\text { dobře viditelná koroze } \\
\text { a fytolitů** }\end{array}$ & $\begin{array}{l}\text { Impregnace fosfáty**; } \\
\text { impregnace mikritickým } \\
\text { karbonátem****; } \\
\text { bioturbace**; stopy po } \\
\text { lezení }{ }^{* *}\end{array}$ & $\begin{array}{l}\text { Silně nevytř́íčná matrix } \\
\text { tvořená kuchyňským } \\
\text { odpadem a min. matrix. } \\
\text { Na bázi světlejší s jemně } \\
\text { rozptýlenými uhlíky. } \\
\text { Ve svrchní části velké } \\
\text { množství uhlíků, } \\
\text { mikritického karbonátu, } \\
\text { organické hmoty } \\
\text { a rozkládajících se kostí. } \\
\text { Fosfáty zde impregnují } \\
\text { přechod mezi subfacií A a B. } \\
\text { Vzniká tak reaktivní vrstva, } \\
\text { která se makroskopicky } \\
\text { projevuje jako jemně } \\
\text { oranžová vrstvička }\end{array}$ \\
\hline Biskupská & $\mathrm{C}$ & $\operatorname{Pr}$ & $\begin{array}{l}\text { Praskliny, které } \\
\text { místy vytváŕí až } \\
\text { subangulární } \\
\text { póry*** }\end{array}$ & $\begin{array}{l}\text { Qzr, Fls, slída, opákní } \\
\text { minerály, úlomky } \\
\text { metabazitů; světle hnědá } \\
\text { barva; Bf krystalický }\end{array}$ & $\begin{array}{l}\text { Rozložená hnědá OH ve } \\
\text { formě tečkování* }\end{array}$ & $\begin{array}{l}\text { Ojedinělé stopy po } \\
\text { lezenít }\end{array}$ & $\begin{array}{l}\text { Vytříděný materiál } \\
\text { redeponované spraše }\end{array}$ \\
\hline $\begin{array}{l}\text { Biskupská } \\
249 / 266\end{array}$ & & $\mathrm{C}$ & $\begin{array}{l}\text { Větší či menší } \\
\text { dutiny } \\
\text { nepravidelného } \\
\text { tvaru**; } \\
\text { praskliny* } \\
\text { a kanálky* }\end{array}$ & $\begin{array}{l}\text { Qzr, Fls, slída, opákní } \\
\text { minerály, polostrohranné } \\
\text { až zaoblené úlomky } \\
\text { hornin metabazitové } \\
\text { zóny; barva matrix je } \\
\text { variabilní díky množství } \\
\text { postdepozičních změn, } \\
\text { v průměru však } \\
\text { šedohnědá; Bf krystalický }\end{array}$ & $\begin{array}{l}\text { Rozložená hnědá OH ve } \\
\text { formě tečkování**; } \\
\text { mikoruhlíky*; } \\
\text { neartikulované fytolity*; } \\
\text { fragmenty kostí+ }\end{array}$ & $\begin{array}{l}\text { Bioturbace***; } \\
\text { fosfatické nodule***; } \\
\text { nodule tvořené } \\
\text { hydroxidy železa**; } \\
\text { fosfáty a hydroxidy } \\
\text { železa tvoŕí také místní } \\
\text { impregnace**, stejně } \\
\text { tak jako impregnace } \\
\text { uhličitanu vápenatého* }\end{array}$ & $\begin{array}{l}\text { Makroskopicky } \\
\text { postedepoziční znaky se } \\
\text { projevují jako šmouhy }\end{array}$ \\
\hline $\begin{array}{l}\text { Biskupská } \\
283 / 284\end{array}$ & A & $\mathrm{C}$ & $\begin{array}{l}\text { Větší či menší } \\
\text { dutiny } \\
\text { nepravidelného } \\
\text { tvaru**; } \\
\text { praskliny*; } \\
\text { kanálky*; } \\
\text { meziagregátové } \\
\text { póry** }\end{array}$ & $\begin{array}{l}\text { Qzr, Fls, slída, opákní } \\
\text { minerály, polostrohranné } \\
\text { úlomky metabazitových } \\
\text { hornin, vápence, } \\
\text { granodioritu, křemence } \\
\text { a propálené matrix; světle } \\
\text { hnědá barva; Bf krystalický, } \\
\text { lokálně striatický } \\
\text { a granostriatický }\end{array}$ & $\begin{array}{l}\text { OH je zastoupena jako } \\
\text { rozložená hnědá } \\
\text { organická hmota ve formě } \\
\text { tečkování**; uhlíků+; } \\
\text { mikrouhlíků** } \\
\text { a rozptýlených fytolitů* }\end{array}$ & $\begin{array}{l}\text { Jílové náteky až } \\
\text { impregnace }{ }^{*} \text { náteky } \\
\text { FeOH na vnitřní okraje } \\
\text { pórů**; občasný výskyt } \\
\text { Fe/Mn nodulí*; stopy } \\
\text { po lezení* a kořenová } \\
\text { bioturbace* }\end{array}$ & $\begin{array}{l}\text { Matrix je místy masivní, ve } \\
\text { velké části však obsahuje } \\
\text { póry netypického tvaru; } \\
\text { materiál je nevytříděný } \\
\text { a nevykazuje usměrnění }\end{array}$ \\
\hline
\end{tabular}




\begin{tabular}{|c|c|c|c|c|c|c|c|}
\hline Vzorek & Subf. & $\mathbf{M}$ & Porozita & Základní hmota & $\begin{array}{l}\text { Organická } \\
\text { a organominerální část }\end{array}$ & Pedostrukturní prvky & Poznámky \\
\hline $\begin{array}{l}\text { Biskupská } \\
283 / 284\end{array}$ & B & $\mathrm{C}$ & $\begin{array}{l}\text { Dutiny } \\
\text { nepravidelného } \\
\text { tvaru**; } \\
\text { horizontální } \\
\text { póry*; } \\
\text { meziagregátové } \\
\text { póry*** }\end{array}$ & $\begin{array}{l}\text { Qzr, Fls, slída, opákní } \\
\text { minerály, sparitický } \\
\text { karbonát, klasty propálené } \\
\text { matrix, struska, úlomky } \\
\text { metabazitových } \\
\text { a granodioritových } \\
\text { hornin; barva matrix je } \\
\text { variabilní, převážně však } \\
\text { hnědá až hnědooranžová; } \\
\text { Bf krystalický lokálně } \\
\text { striatický }\end{array}$ & $\begin{array}{l}\text { OH ve formě rozložené } \\
\text { organické hmoty**; } \\
\text { mikrouhlíků*; uhlíků*; } \\
\text { artikulovaných fytolitů, } \\
\text { které tvoří minimálně tři } \\
\text { polohy**; přepálených } \\
\text { a nepřepálených kostí* }\end{array}$ & $\begin{array}{l}\text { Bioturbace*; stopy po } \\
\text { lezení*; exkrementy } \\
\text { mikrofauny*; jílovité } \\
\text { náteky především ve } \\
\text { spojení s akumulacemi } \\
\text { uhlíků** }\end{array}$ & $\begin{array}{l}\text { Výskyt horizontálních pórů } \\
\text { je vázán na akumulace } \\
\text { fytolitů }\end{array}$ \\
\hline Orlí 151 & & $\operatorname{Pr}$ & $\begin{array}{l}\text { Praskliny**; } \\
\text { meziagregátové } \\
\text { póry**; kanálky*** }\end{array}$ & $\begin{array}{l}\text { Qzr, Fls, slída, opákní } \\
\text { minerály, ojediněle } \\
\text { přitomny sparitické } \\
\text { karbonáty jako } \\
\text { pseudomorfózy po } \\
\text { kořenových buňkách } \\
\text { nebo ostrohranné klasty } \\
\text { hornin brněnského } \\
\text { masivu; světle hnědá } \\
\text { barva; Bf krystalický }\end{array}$ & $\begin{array}{l}\text { OH je zastoupena ve } \\
\text { formě rozložené hnědé } \\
\text { hmoty jako tečkování**; } \\
\text { dále pak ojedinělých } \\
\text { mikrouhlíků+ }\end{array}$ & $\begin{array}{l}\text { Bioturbace } * * * * ; \\
\text { exkremety } \\
\text { mikrofauny**; Fe/Mn } \\
\text { nodule* }^{*}\end{array}$ & $\begin{array}{l}\text { Extrémní bioturbace, není } \\
\text { zřetelné horizontální } \\
\text { usměrnění }\end{array}$ \\
\hline $\begin{array}{l}\text { Orlí } \\
75 / 08 / 05\end{array}$ & A & $\mathrm{C} / \mathrm{M}$ & $\begin{array}{l}\text { Z velké části } \\
\text { masivní, místy } \\
\text { dutiny } \\
\text { nepravidelného } \\
\text { tvaru*; praskliny* } \\
\text { a kanálky* }\end{array}$ & $\begin{array}{l}\text { Qzr, Fls, slída, opákní } \\
\text { minerály s minimem } \\
\text { příměsi klastů hornin } \\
\text { metabazitové zóny; } \\
\text { světle hnědá barva; } \\
\text { Bf krystalický }\end{array}$ & $\begin{array}{l}\text { OH je zastoupena ve } \\
\text { formě rozložené hnědé } \\
\text { hmoty jako tečkování* }\end{array}$ & $\begin{array}{l}\text { Náteky nebo } \\
\text { impregnace FeOH**; } \\
\text { nebo CaCO3*; občasně } \\
\text { byly zaznamenány i } \\
\text { malé nodule Fe/Mn+ } \\
\text { nebo akumulace } \\
\text { sparitického karbonátu } \\
\text { jako pseudomorfózy po } \\
\text { kořenových buňkách* }\end{array}$ & Velmi dobré vytřídění \\
\hline $\begin{array}{l}\text { Orlí } \\
75 / 08 / 05\end{array}$ & B & $\mathrm{C} / \mathrm{M}$ & $\begin{array}{l}\text { Z velké části } \\
\text { masivní, } \\
\text { místy dutiny } \\
\text { nepravidelného } \\
\text { tvaru*; } \\
\text { horizontální póry* }\end{array}$ & $\begin{array}{l}\text { Qzr, Fls, slída, opákní } \\
\text { minerály, př́padně } \\
\text { jednotlivými krystaly } \\
\text { sparitického karbonátu; } \\
\text { barva je světle hnědo } \\
\text { šedá; Bf krystalický. }\end{array}$ & $\begin{array}{l}\text { OH je zastoupena ve } \\
\text { formě rozložené hnědé } \\
\text { hmoty jako tečkování* }\end{array}$ & $\begin{array}{l}\text { Deplece****; } \\
\text { iluviační proplástek, } \\
\text { který reprezentuje } \\
\text { akumulaci hydroxidů } \\
\text { železa**; svrchní ćást } \\
\text { této subfacie je } \\
\text { postižena bioturbací** } \\
\text { a obsahuje exkrementy } \\
\text { mikrofauny* }\end{array}$ & $\begin{array}{l}\text { Sediment je to velmi } \\
\text { dobře vytř́iěný s viditelnou } \\
\text { pozitivní gradací } \\
\text { a horizontálním } \\
\text { usměrněním; facie typická } \\
\text { deplecí, tj. odstraněním } \\
\text { hydroxidů železa, které má } \\
\text { za následek zesvětlení } \\
\text { matrix }\end{array}$ \\
\hline $\begin{array}{l}\text { Orlí } \\
75 / 08 / 05\end{array}$ & C & $\mathrm{C}$ & $\begin{array}{l}\text { Meziagregátové } \\
\text { póry**; dutiny } \\
\text { nepravidelného } \\
\text { tvaru*; praskliny* }\end{array}$ & $\begin{array}{l}\text { Qzr, Fls, slída, opákní } \\
\text { minerály propálenou } \\
\text { matrix, klasty hornin } \\
\text { metabazitové zóny } \\
\text { a sparitickým karbonátem; } \\
\text { barva matrix je hnědá; } \\
\text { Bf krystalický }\end{array}$ & $\begin{array}{l}\text { OH částečně rozložená+ } \\
\text { a rozložená** hnědá } \\
\text { organická hmota; } \\
\text { mikrouhlíky* a uhlíky+; } \\
\text { kosti+; propálené kosti+; } \\
\text { rozptýlené fytolity+, } \\
\text { případně fragmenty } \\
\text { skořápek vajec+ }\end{array}$ & $\begin{array}{l}\text { Bioturbace (kořenová } \\
\text { bioturbace* a stopy } \\
\text { po lezení**); jednotlivé } \\
\text { agregáty se stopami } \\
\text { po lezení tvoŕí velkou } \\
\text { ćást studované matrix; } \\
\text { exkrementy } \\
\text { mikrofauny** }\end{array}$ & $\begin{array}{l}\text { Nehomogenní nevytříděná; } \\
\text { typická je přítomnost } \\
\text { subangulárních klastů } \\
\text { půdní matrix, která v sobě } \\
\text { nese známky usměrnění }\end{array}$ \\
\hline $\begin{array}{l}\text { Orlí } \\
75 / 08 / 06\end{array}$ & A & $\mathrm{C} / \mathrm{M}$ & $\begin{array}{l}\text { Z velké části } \\
\text { masivní, místy } \\
\text { dutiny } \\
\text { nepravidelného } \\
\text { tvaru*; kanálky* }\end{array}$ & $\begin{array}{l}\text { Qzr, Fls, slída, opákní } \\
\text { minerály; barva matrix } \\
\text { je světle hnědá; } \\
\text { Bf krystalický. }\end{array}$ & $\begin{array}{l}\text { OH je zastoupena ve } \\
\text { formě rozložené hnědé } \\
\text { hmoty jako tečkování* }\end{array}$ & $\begin{array}{l}\text { Náteky nebo } \\
\text { impregnace FeOH, } \\
\text { nebo } \mathrm{CaCO} 3^{* *} \text {; malé } \\
\text { nodule } \mathrm{Fe} / \mathrm{Mn}^{*} ; \\
\text { akumulace sparitického } \\
\text { karbonátu jako } \\
\text { pseudomorfózy po } \\
\text { kořenových } \\
\text { buňkách**** }\end{array}$ & $\begin{array}{l}\text { Přechod mezi facií A a B } \\
\text { je velmi ostrý, zvýrazněný } \\
\text { př́tomností mikrovstvičky } \\
\text { tvořené nespáleným } \\
\text { rozloženým dřevem }\end{array}$ \\
\hline $\begin{array}{l}\text { Orlí } \\
75 / 08 / 06\end{array}$ & B & $\mathrm{C}$ & $\begin{array}{l}\text { Meziagregátové } \\
\text { póry**; praskliny } \\
\text { a dutiny } \\
\text { nepravidelného } \\
\text { tvaru*** }\end{array}$ & $\begin{array}{l}\text { Qzr, Fls, slída, opákní } \\
\text { minerály, úlomky hornin } \\
\text { metabazitové zóny; matrix } \\
\text { je hnědá; Bf krystalický }\end{array}$ & $\begin{array}{l}\text { Rozložená*** a částečně } \\
\text { rozložená* OH; } \\
\text { mikrouhlíky* a uhlíky*; } \\
\text { místy zřetelné } \\
\text { horizontální usměrnění } \\
\text { kopírující nerovnosti } \\
\text { povrchu; je částečně } \\
\text { zvýrazněno } \\
\text { artikulovanými fytolity*; } \\
\text { fragmenty spálených+ } \\
\text { a nespálených+ kostních } \\
\text { fragmentů a fekální } \\
\text { sferulity* }\end{array}$ & $\begin{array}{l}\text { Bioturbace**, resp. } \\
\text { stopy po lezení } \\
\text { a exkrementy } \\
\text { mikrofauny }\end{array}$ & $\begin{array}{l}\text { Aktivní část podlahového } \\
\text { setu - jde o nevytříděný } \\
\text { materiál tvořený z velké } \\
\text { části kuchyňským odpadem } \\
\text { smíchaným s minerální } \\
\text { matrix; vrstva jeví zřetelné } \\
\text { známky usměrnění }\end{array}$ \\
\hline $\begin{array}{l}\text { Orlí } \\
75 / 08 / 06\end{array}$ & C & C & $\begin{array}{l}\text { Dutiny } \\
\text { nepravidelného } \\
\text { tvaru*; praskliny*; } \\
\text { meziagregátové } \\
\text { póry** a kanálky* }\end{array}$ & $\begin{array}{l}\text { Qzr, Fls, slída, opákní } \\
\text { minerály; matrix je hnědá; } \\
\text { Bf krystalický }\end{array}$ & $\begin{array}{l}\text { OH je zastoupena ve } \\
\text { formě rozložené hnědé } \\
\text { hmoty jako tečkování*; } \\
\text { mikrouhlíky+ }\end{array}$ & $\begin{array}{l}\text { Kořenová bioturbace } \\
\text { a stopy po lezení** } \\
\text { spolu s exkrementy } \\
\text { mikrofauny*; } \\
\text { impregnace matrix } \\
\text { nebo okrajů pórů } \\
\text { hyroxidy železa* }\end{array}$ & $\begin{array}{l}\text { Pasivní konstrukční } \\
\text { podlahová vrstva tvořená } \\
\text { redeponovanou spraší }\end{array}$ \\
\hline
\end{tabular}




\begin{tabular}{|c|c|c|c|c|c|c|c|}
\hline Vzorek & Subf. & $\mathbf{M}$ & Porozita & Základní hmota & $\begin{array}{l}\text { Organická } \\
\text { a organominerální část }\end{array}$ & Pedostrukturní prvky & Poznámky \\
\hline $\begin{array}{l}\text { Orlí } \\
75 / 08 / 06\end{array}$ & $\mathrm{D}$ & $\mathrm{C}$ & $\begin{array}{l}\text { Praskliny*; } \\
\text { meziagregátové } \\
\text { póry* a dutiny } \\
\text { nepravidelného } \\
\text { tvaru* }\end{array}$ & $\begin{array}{l}\text { Qzr, Fls, slída, opákní } \\
\text { minerály, zakulacené } \\
\text { fragmenty hornin } \\
\text { metabazitové zóny } \\
\text { a brněnského masivu, } \\
\text { závalky propálené matrix; } \\
\text { barva je variabilní, } \\
\text { průměrně hnědá; } \\
\text { Bf krystalický }\end{array}$ & $\begin{array}{l}\text { Hnědá až žlutohnědá } \\
\text { OH**; mikrouhlíky* } \\
\text { a uhlíky*; fragmenty } \\
\text { spálených kostí+ }\end{array}$ & $\begin{array}{l}\text { Bioturbace**, } \\
\text { především stopy po } \\
\text { lezení a exkrementy } \\
\text { mikrofauny které jsou } \\
\text { často silně fosfatické }\end{array}$ & $\begin{array}{l}\text { Makroskopicky relativně } \\
\text { výrazná, mikroskopicky je } \\
\text { však tvořena především } \\
\text { postdepozičními změnami } \\
\text { souvisejícími s rozkladem } \\
\text { organické hmoty }\end{array}$ \\
\hline $\begin{array}{l}\text { Orlí } \\
75 / 08 / 06\end{array}$ & $\mathrm{E}$ & $\mathrm{C} / \mathrm{M}$ & $\begin{array}{l}\text { Praskliny*; } \\
\text { meziagregátové } \\
\text { póry* a dutiny } \\
\text { nepravidelného } \\
\text { tvaru* }\end{array}$ & $\begin{array}{l}\text { Qzr, Fls, slída, opákní } \\
\text { minerály objevují se však } \\
\text { i závalky propálené matrix } \\
\text { a fragmenty hornin } \\
\text { metabazitové zóny, } \\
\text { brněnského masivu } \\
\text { a vápence; matrix je } \\
\text { hnědá; Bf krystalický }\end{array}$ & $\begin{array}{l}\text { OH je zastoupena ve } \\
\text { formě rozložené hnědé } \\
\text { hmoty jako tečkování; } \\
\text { mikrouhlíky+ }\end{array}$ & $\begin{array}{l}\text { Bioturbace** (stopy po } \\
\text { lezení spojené } \\
\text { s přítomností } \\
\text { exkrementů } \\
\text { mikrofauny); } \\
\text { impregnace fosfáty* } \\
\text { a hydroxidy železa* } \\
\text { z rozkládající se } \\
\text { organické hmoty } \\
\text { deponované } \\
\text { pravděpodobně } \\
\text { v nadloží. }\end{array}$ & $\begin{array}{l}\text { Zásyp nebo další pasivní } \\
\text { vrstva }\end{array}$ \\
\hline $\begin{array}{l}\text { Orlí } \\
75 / 08 / 07\end{array}$ & A & $\mathrm{C} / \mathrm{M}$ & $\begin{array}{l}\text { Přerušovaná } \\
\text { výskytem } \\
\text { horizontálních } \\
\text { pórư* nebo dutin } \\
\text { nepravidelného } \\
\text { tvaru* }\end{array}$ & $\begin{array}{l}\text { Qzr, Fls, slída, opákní } \\
\text { minerály ojediněle je } \\
\text { prrítomen fragment } \\
\text { vápence; barva je světle } \\
\text { hnědá; Bf krystalický }\end{array}$ & $\begin{array}{l}\text { OH je zastoupena ve } \\
\text { formě rozložené hnědé } \\
\text { hmoty jako tečkování*; } \\
\text { uhlíky+ a mikrouhlíky+ }\end{array}$ & $\begin{array}{l}\text { Impregnace a náteky } \\
\text { FeOH a pravděpodobně } \\
\text { i fosfátů na vnitřní } \\
\text { straně horizontálních } \\
\text { pórů a struktur po } \\
\text { bioturbaci }\end{array}$ & $\begin{array}{l}\text { Relativně vytř̌íděná, bez } \\
\text { známek usměrnění }\end{array}$ \\
\hline $\begin{array}{l}\text { Orlí } \\
75 / 08 / 07\end{array}$ & B & $\mathrm{C}$ & $\begin{array}{l}\text { Horizontální } \\
\text { póry**; dutiny } \\
\text { nepravidelného } \\
\text { tvaru** }\end{array}$ & $\begin{array}{l}\text { Qzr, Fls, slída, opákní } \\
\text { minerály ojediněle } \\
\text { fragmenty hornin } \\
\text { metabazitové zóny; } \\
\text { barva matrix je hnědá; } \\
\text { Bf krystalický }\end{array}$ & $\begin{array}{l}\text { Rozložená } \mathrm{OH}^{* *} ; \\
\text { mikrouhlíky*; uhlíky+ } \\
\text { artikulované* } \\
\text { a rozptýlené fytolity+; } \\
\text { skořápky vajec+; množství } \\
\text { organogenních inkluzí } \\
\text { není př́liš vysoké } \\
\text { a převažuje minerální } \\
\text { matrix }\end{array}$ & $\begin{array}{l}\text { Impregnace Fe a P } \\
\text { v matrix a na okrajích } \\
\text { pórů**; bioturbace** } \\
\text { a s ní související } \\
\text { pŕítomnost exkrementů } \\
\text { mikrofauny*; ve vzorku } \\
\text { byly detekovány také } \\
\text { iluviační vrstvičky* }\end{array}$ & $\begin{array}{l}\text { Matrix jeví zřetelné známky } \\
\text { usměrnění }\end{array}$ \\
\hline $\begin{array}{l}\text { Orlí } \\
75 / 08 / 07\end{array}$ & C & $\mathrm{C}$ & $\begin{array}{l}\text { Horizontální } \\
\text { póry**; dutiny } \\
\text { nepravidelného } \\
\text { tvaru**; } \\
\text { praskliny* }\end{array}$ & $\begin{array}{l}\text { Qzr, Fls, slída, opákní } \\
\text { minerály, fragmenty } \\
\text { magmatických } \\
\text { a metamorfovaných hornin, } \\
\text { propálené fragmenty } \\
\text { matrix a vápnitého tmelu; } \\
\text { barva je světle hnědá; } \\
\text { Bf krystalický. }\end{array}$ & $\begin{array}{l}\text { OH je zastoupena ve } \\
\text { formě rozložené hnědé } \\
\text { hmoty jako tečkování*; } \\
\text { uhlíky+ a mikrouhlíky+ }\end{array}$ & $\begin{array}{l}\text { FeOH a fosfatické } \\
\text { nodule až } \\
\text { impregnace***; } \\
\text { bioturbace spojená } \\
\text { s výskytem exkrementů } \\
\text { mikrofauny* a místy } \\
\text { kořenová bioturbace+ }\end{array}$ & \\
\hline Panenská 1 & A & $\mathrm{C} / \mathrm{M}$ & $\begin{array}{l}\text { Ve spodní části je } \\
\text { relativně masivní } \\
\text { s póry typu } \\
\text { kanálky* a dutiny } \\
\text { nepravidelného } \\
\text { tvaru*; na } \\
\text { přechodu se } \\
\text { subfacií B má } \\
\text { množství } \\
\text { horizontálních } \\
\text { pórů*** }\end{array}$ & $\begin{array}{l}\text { Qzr, Fls, slída, opákní } \\
\text { minerály, sparitický } \\
\text { karbonát, zaoblené klasty } \\
\text { metamorfovaných hornin; } \\
\text { barva matrix je světle } \\
\text { hnědá; Bf krystalický }\end{array}$ & $\begin{array}{l}\text { OH je zastoupena ve } \\
\text { formě rozložené hnědé } \\
\text { hmoty jako tečkování*; } \\
\text { uhlíky+ a mikrouhlíky+ }\end{array}$ & $\begin{array}{l}\text { Impregnace a náteky } \\
\text { CaCO3**; } \\
\text { pseudomorfózy } \\
\text { sparitického karbonátu } \\
\text { po kořenových } \\
\text { buňkách*; kořenová } \\
\text { bioturbace a stopy po } \\
\text { lezení*; Fe/Mn nodule } \\
\text { různého tvaru*; } \\
\text { impregnace bohatá na } \\
\text { Fe a pravděpodobně } \\
\text { i fosfáty+ }\end{array}$ & $\begin{array}{l}\text { Póry, kterých je poměrně } \\
\text { velké množství nevykazují } \\
\text { př́tomnost náteků; } \\
\text { horizontální usměrnění } \\
\text { neidentifikováno }\end{array}$ \\
\hline Panenská 1 & B & $\mathrm{C}$ & $\begin{array}{l}\text { Dutiny } \\
\text { nepravidelného } \\
\text { tvaru** } \\
\text { a horizontální } \\
\text { praskliny** }\end{array}$ & $\begin{array}{l}\text { Qzr, Fls, slída, opákní } \\
\text { minerály fragmenty } \\
\text { metamorfovaných hornin, } \\
\text { křemence a vápence; } \\
\text { barva matrix je variabilní } \\
\text { od hnědé po } \\
\text { hnědooranžovou; } \\
\text { Bf krystalický }\end{array}$ & $\begin{array}{l}\text { OH částečně rozložená+ } \\
\text { a rozložená** hnědá } \\
\text { organická hmota; } \\
\text { mikrouhlíky* a uhlíky+; } \\
\text { kosti+; propálené kosti+ } \\
\text { a rozptýlené fytolity+, } \\
\text { př́padně fragmenty } \\
\text { skořápek vajec+ }\end{array}$ & $\begin{array}{l}\text { Horizontálně uložené } \\
\text { iluviální vrstvičky** } \\
\text { kopírující horizontální } \\
\text { póry nebo akumulace } \\
\text { uhlíků; složení } \\
\text { z mikritického } \\
\text { karbonátu, fosfatické } \\
\text { matrix nebo matrix } \\
\text { bohaté na železo; ve } \\
\text { svrchní ćásti zachyceny } \\
\text { akumulace tzv. půdních } \\
\text { krust, které vznikají } \\
\text { např́iklad vysycháním } \\
\text { kaluží }\end{array}$ & $\begin{array}{l}\text { Místy zřetelné usměrnění, } \\
\text { v některých prrípadech } \\
\text { zvýrazněné príítomností } \\
\text { tenkých proplástků } \\
\text { tvořených mikritickým } \\
\text { karbonátem nebo fosfáty; } \\
\text { fosfatické náteky jsou místy } \\
\text { v prrímém kontaktu } \\
\text { s vrstvou mikrouhlíků }\end{array}$ \\
\hline Panenská 1 & $\mathrm{C}$ & $\operatorname{Pr}$ & $\begin{array}{l}\text { Praskliny** } \\
\text { a dutiny } \\
\text { nepravidelného } \\
\text { tvaru* }\end{array}$ & $\begin{array}{l}\text { Qzr, Fls, slída, opákní } \\
\text { minerály s občasným } \\
\text { výskytem fragmentů } \\
\text { metamorfovaných hornin; } \\
\text { barva matrix je hnědá až } \\
\text { hnědooranžová; } \\
\text { Bf striatický }\end{array}$ & $\begin{array}{l}\text { OH částečně rozložená+ } \\
\text { a rozložená** hnědá } \\
\text { organická hmota; } \\
\text { mikrouhlíky* }\end{array}$ & $\begin{array}{l}\text { Impregnace hydroxidy } \\
\text { železa na okrajích } \\
\text { pórů** }\end{array}$ & $\begin{array}{l}\text { Homogenní bez usměrnění; } \\
\text { na okrajích pórů je } \\
\text { impregnace hydroxidy } \\
\text { železa díky oxidačně } \\
\text { redukčním procesům } \\
\text { a rozkládající se organické } \\
\text { hmotě }\end{array}$ \\
\hline
\end{tabular}




\begin{tabular}{|c|c|c|c|c|c|c|c|}
\hline Vzorek & Subf. & M & Porozita & Základní hmota & $\begin{array}{l}\text { Organická } \\
\text { a organominerální část }\end{array}$ & Pedostrukturní prvky & Poznámky \\
\hline Panenská 2 & A & $\mathrm{C}$ & $\begin{array}{l}\text { Meziagregátové } \\
\text { póry***; dutiny } \\
\text { nepravidelného } \\
\text { tvaru* a kanálky* }\end{array}$ & $\begin{array}{l}\text { Qzr, Fls, slída, opákní } \\
\text { minerály, klasty hornin } \\
\text { nebyly zastiženy; barva je } \\
\text { světle hnědá; Bf krystalický }\end{array}$ & $\begin{array}{l}\text { OH je zastoupena ve } \\
\text { formě rozložené hnědé } \\
\text { hmoty jako tečkování* }\end{array}$ & $\begin{array}{l}\text { Bioturbace spojená s } \\
\text { výskytem exkrementů } \\
\text { mikrofauny*; výskyt } \\
\text { sparitického karbonátu } \\
\text { jako pseudomorfózy po } \\
\text { kořenových buňkách* }\end{array}$ & $\begin{array}{l}\text { Homogenní bez známek } \\
\text { horizontálního usměrnění - } \\
\text { spraš }\end{array}$ \\
\hline Panenská 2 & B & C & $\begin{array}{l}\text { Meziagregátové } \\
\text { póry**; dutiny } \\
\text { nepravidelného } \\
\text { tvaru* a praskliny* }\end{array}$ & $\begin{array}{l}\text { Qzr, Fls, slída, opákní } \\
\text { minerály místy i sparitický } \\
\text { karbonát a ojediněle } \\
\text { úlomky metabazitových } \\
\text { hornin; barva je hnědá až } \\
\text { světle hnědá; Bf krystalický }\end{array}$ & $\begin{array}{l}\text { OH rozložená, hnědá ve } \\
\text { formě tečkování**; } \\
\text { fragmenty rozložené } \\
\text { organické hmoty*; } \\
\text { mikrouhlíky*; uhlíky+; } \\
\text { fragmenty kostí+ } \\
\text { a ojedinělými fytolity+ }\end{array}$ & $\begin{array}{l}\text { Bioturbace** (stopy po } \\
\text { lezení a s tím spojeným } \\
\text { výskytem exkrementů* } \\
\text { mikrofauny) }\end{array}$ & $\begin{array}{l}\text { Materiál facie je zrnitostně } \\
\text { relativně vytříděný, ale je } \\
\text { složen z množství půdních } \\
\text { agregátů smíchaných } \\
\text { s agregáty redeponované } \\
\text { spraše }\end{array}$ \\
\hline Panenská 2 & C & $\mathrm{P}$ & $\begin{array}{l}\text { Horizontální } \\
\text { póry***; } \\
\text { meziagregátové } \\
\text { póry**; dutiny } \\
\text { nepravidelného } \\
\text { tvaru* }\end{array}$ & $\begin{array}{l}\text { Qzr, Fls, slída, opákní } \\
\text { minerály; barva je světle } \\
\text { hnědá; Bf krystalický }\end{array}$ & $\begin{array}{l}\text { OH rozložená, hnědá ve } \\
\text { formě tečkování* }\end{array}$ & $\begin{array}{l}\text { Bioturbace spojená } \\
\text { s výskytem exkrementů } \\
\text { mikrofauny**; } \\
\text { sparitický karbonát* } \\
\text { jako pseudomorfózy po } \\
\text { kořenových buňkách. }\end{array}$ & $\begin{array}{l}\text { homogenní bez známek } \\
\text { horizontálního usměrnění }\end{array}$ \\
\hline Panenská 2 & $\mathrm{D}$ & C & $\begin{array}{l}\text { Dutiny } \\
\text { nepravidelného } \\
\text { tvaru** a místy } \\
\text { meziagregátové } \\
\text { póry* }\end{array}$ & $\begin{array}{l}\text { Qzr, Fls, slída, opákní } \\
\text { minerály, dále pak } \\
\text { fragmentů } \\
\text { metabazitových hornin, } \\
\text { propálené matrix } \\
\text { a fragmentu keramiky; } \\
\text { barva matrix je hnědá; } \\
\text { Bf krystalický }\end{array}$ & $\begin{array}{l}\text { OH ve formě hnědé } \\
\text { rozložené jako } \\
\text { tečkování**; dále pak } \\
\text { útržků částečně rozložené } \\
\text { organické hmoty*; } \\
\text { mikrouhlíků* a místy } \\
\text { uhlíků+ a spálených/ } \\
\text { nespálených fragmentů } \\
\text { kostí+ }\end{array}$ & Bioturbace* & $\begin{array}{l}\text { V rámci vzorku byly } \\
\text { detekovány fragmenty } \\
\text { půdních agregátů } \\
\text { a fragmenty agregátů } \\
\text { redeponované spraše; } \\
\text { horizontální usměrnění } \\
\text { zvýrazněné prítomností } \\
\text { mikrouhlíků je viditelné } \\
\text { pouze v malé ploše } \\
\text { popisované vrstvy }\end{array}$ \\
\hline Panenská 2 & $\mathrm{E}$ & C & $\begin{array}{l}\text { Meziagregátové } \\
\text { póry**; dutiny } \\
\text { nepravidelného } \\
\text { tvaru*; kanálky***; } \\
\text { ve svrchní ćásti } \\
\text { horizontální } \\
\text { póry*** }\end{array}$ & $\begin{array}{l}\text { Qzr, Fls, slída, opákní } \\
\text { minerály klasty } \\
\text { metamorfovaných } \\
\text { a vyvřelých hornin, } \\
\text { množství sparitického } \\
\text { karbonátu vznikajícího } \\
\text { jako pseudomorfózy po } \\
\text { kořenových buňkách; } \\
\text { barva je světle hnědá; } \\
\text { Bf krystalický }\end{array}$ & $\begin{array}{l}\text { OH ve formě hnědé } \\
\text { rozložené jako tečkování* }\end{array}$ & $\begin{array}{l}\text { Bioturbace spojená } \\
\text { s výskytem exkrementů } \\
\text { mikrofauny*; sparitický } \\
\text { karbonát*** jako } \\
\text { pseudomorfózy po } \\
\text { kořenových buňkách, } \\
\text { který ćástečně vyplňuje } \\
\text { četné kanálky }\end{array}$ & $\begin{array}{l}\text { Je homogenní bez známek } \\
\text { horizontálního usměrnění, } \\
\text { středně vytř́íděná }\end{array}$ \\
\hline Panenská 2 & $\mathrm{~F}$ & $\mathrm{C} / \mathrm{G}$ & $\begin{array}{l}\text { Místy } \\
\text { meziagregátové } \\
\text { póry až****; } \\
\text { místy praskliny** } \\
\text { nebo dutiny } \\
\text { nepravidelného } \\
\text { tvaru* }\end{array}$ & $\begin{array}{l}\text { Qzr, Fls, slída, opákní } \\
\text { minerály, klasty propálené } \\
\text { matrix, ojediněle } \\
\text { fragmenty } \\
\text { metamorfovaných hornin; } \\
\text { barva matrix je variabilní } \\
\text { hnědá, tmavě hnědá, } \\
\text { oranžově hnědá; } \\
\text { Bf krystalický }\end{array}$ & $\begin{array}{l}\text { Rozložená jemnozrnná } \\
\text { hnědá organická hmota*; } \\
\text { mikrouhlíky*** a uhlíky*; } \\
\text { fytolity+ a spálené kostní } \\
\text { fragmenty+ }\end{array}$ & $\begin{array}{l}\text { Bioturbace**, } \\
\text { především stopy po } \\
\text { lezení a s tím } \\
\text { související } \\
\text { exkrementální } \\
\text { mikrostruktury }\end{array}$ & $\begin{array}{l}\text { Subfacie F je tvořena } \\
\text { množstvím uhlíků, které } \\
\text { jsou převládající složkou } \\
\text { této vrstvy; ve vzorku je } \\
\text { patrné horizontální } \\
\text { usměrnění minerální } \\
\text { matrix a uhlíků; přechod } \\
\text { do podloží způsobený } \\
\text { propálením }\end{array}$ \\
\hline Panenská 2 & G & C & $\begin{array}{l}\text { Dutiny } \\
\text { nepravidelného } \\
\text { tvaru**; } \\
\text { meziagregátové } \\
\text { póry* a kanálky+ }\end{array}$ & $\begin{array}{l}\text { Qzr, Fls, slída, opákní } \\
\text { minerály, fragmenty } \\
\text { metabazitových hornin } \\
\text { a propálených klastů } \\
\text { matrix; barva matrix } \\
\text { je světle hnědá až } \\
\text { hnědooranžová; } \\
\text { Bf krystalický }\end{array}$ & $\begin{array}{l}\text { OH hnědá, rozložená ve } \\
\text { formě tečkování*; } \\
\text { fragmenty rozložené } \\
\text { organické hmoty*; } \\
\text { mikrouhlíky* a uhlíky+; } \\
\text { spálené fragmenty kostí+ } \\
\text { a samostatné fytolity+ }\end{array}$ & $\begin{array}{l}\text { Hlavním } \\
\text { pedostrukturním } \\
\text { prvkem jsou stopy po } \\
\text { lezení****; místy jsou } \\
\text { tak intenzivní } \\
\text { a opakovaně na jedné } \\
\text { ploše, že vytváří } \\
\text { systém usměrnění } \\
\text { matrix, který se mění } \\
\text { v rámci milimetrů }\end{array}$ & $\begin{array}{l}\text { Vzorek je nevytříděný } \\
\text { a nevykazuje známky } \\
\text { horizontálního usměrnění. } \\
\text { Viditelné usměrnění je } \\
\text { výsledkem stop po lezení, } \\
\text { které jsou extrémně } \\
\text { intenzivní }\end{array}$ \\
\hline Panenská 2 & $\mathrm{H}$ & $\mathrm{C}$ & $\begin{array}{l}\text { Meziagregátové } \\
\text { póry**; dutiny } \\
\text { nepravidelného } \\
\text { tvaru* a kanálky* }\end{array}$ & $\begin{array}{l}\text { Qzr, Fls, slída, opákní } \\
\text { minerály, na přechodu se } \\
\text { subfacií G obsahuje klasty } \\
\text { půdních agregátů; barva } \\
\text { je světle hnědá; } \\
\text { Bf krystalický }\end{array}$ & $\begin{array}{l}\text { OH hnědá, rozložená ve } \\
\text { formě tečkování* }\end{array}$ & $\begin{array}{l}\text { Bioturbace spojená } \\
\text { s výskytem exkrementů } \\
\text { mikrofauny**; } \\
\text { sparitický karbonát } \\
\text { jako pseudomorfóza po } \\
\text { kořenových buňkách* }\end{array}$ & $\begin{array}{l}\text { Je homogenní bez známek } \\
\text { horizontálního usměrnění }\end{array}$ \\
\hline Panenská 3 & A & $\mathrm{C}$ & $\begin{array}{l}\text { Vertikální } \\
\text { pukliny**; } \\
\text { kanálky*; } \\
\text { meziagregátové } \\
\text { póry* a dutiny } \\
\text { nepravidelného } \\
\text { tvaru+ }\end{array}$ & $\begin{array}{l}\text { Qzr, Fls, slída, opákní } \\
\text { minerály a sparitický } \\
\text { karbonát ve výplni pórů } \\
\text { kořenové bioturbace, } \\
\text { klasty hornin nebyly } \\
\text { zastiženy; barva je světle } \\
\text { hnědá; Bf krystalický }\end{array}$ & $\begin{array}{l}\text { OH hnědá, rozložená ve } \\
\text { formě tečkování }\end{array}$ & $\begin{array}{l}\text { Bioturbace lezením } \\
\text { spojená s výskytem } \\
\text { exkrementů } \\
\text { mikrofauny**; } \\
\text { kořenová bioturbace } \\
\text { s výskytem } \\
\text { sparitického karbonátu } \\
\text { jako pseudomorfózy po } \\
\text { kořenových buňkách* }\end{array}$ & $\begin{array}{l}\text { Výskyt horizontálních pórů } \\
\text { v nejsvrchnějších částech } \\
\text { této facie je téměř } \\
\text { zanedbatelný; facie je } \\
\text { homogenní bez známek } \\
\text { horizontálního usměrnění }\end{array}$ \\
\hline
\end{tabular}




\begin{tabular}{|c|c|c|c|c|c|c|c|}
\hline Vzorek & Subf. & $\mathbf{M}$ & Porozita & Základní hmota & $\begin{array}{l}\text { Organická } \\
\text { a organominerální část }\end{array}$ & Pedostrukturní prvky & Poznámky \\
\hline Panenská 3 & B & Pr & $\begin{array}{l}\text { Krátké rozvětvené } \\
\text { praskliny**; } \\
\text { meziagregátové } \\
\text { póry*; ve svrchní } \\
\text { části horizontální } \\
\text { pukliny* } \\
\text { a kanálky+ }\end{array}$ & $\begin{array}{l}\text { Qzr, Fls, slída, opákní } \\
\text { minerály a občasnými } \\
\text { úlomky metabazitových } \\
\text { hornin nebo klasty } \\
\text { propálené matrix; } \\
\text { barva matrix je variabilní } \\
\text { od šedé, po světle } \\
\text { hnědou, hnědou } \\
\text { a hnědooranžovou; } \\
\text { Bf krystalický }\end{array}$ & $\begin{array}{l}\text { OH rozložená hnědá ve } \\
\text { formě tečkování*, } \\
\text { fragmenty rozložené } \\
\text { hnědé organické hmoty*; } \\
\text { zbytky nerozložené } \\
\text { organické hmoty (dřevo)*; } \\
\text { mikrouhlíky*; uhlíky+, } \\
\text { fytolity+; skořápky vajec+; } \\
\text { spálenými a nespálenými } \\
\text { kostmi+ }\end{array}$ & $\begin{array}{l}\text { Fosfatické iluviální } \\
\text { horizonty**; lokální } \\
\text { impregnace } \\
\text { mikritickým } \\
\text { karbonátem*, } \\
\text { místy propojeným } \\
\text { s prrítomností } \\
\text { mikrouhlíků* indikující } \\
\text { popel jako jeho zdroj; } \\
\text { deplece*; bioturbace } \\
\text { spojená s výskytem } \\
\text { exkrementů } \\
\text { mikrofauny* }\end{array}$ & $\begin{array}{l}\text { Relativně nehomogenní, } \\
\text { i když dobře vytř́děná; } \\
\text { znatelné horizontální } \\
\text { usměrnění minerální } \\
\text { matrix nezvýrazněné } \\
\text { přítomností organické } \\
\text { hmoty; ve svrchní části } \\
\text { usměrnění spojeno } \\
\text { i s laminami fosfatické } \\
\text { matrix }\end{array}$ \\
\hline Panenská 3 & $\mathrm{C}$ & Pr & $\begin{array}{l}\text { Vertikálními } \\
\text { póry**; } \\
\text { meziagregátové } \\
\text { póry*, dutiny } \\
\text { nepravidelného } \\
\text { tvaru* a kanálky+ }\end{array}$ & $\begin{array}{l}\text { Qzr, Fls, slída, opákní } \\
\text { minerály, klasty } \\
\text { metamorfoovaných } \\
\text { hornin, fragmenty } \\
\text { propálené matrix; barva } \\
\text { je světle hnědá; } \\
\text { Bf krystalický }\end{array}$ & $\begin{array}{l}\text { Rozložená organická } \\
\text { hmota (tečkování)*; } \\
\text { uhlíky* nebo fragmenty } \\
\text { částečně rozložené } \\
\text { organické hmoty+ }\end{array}$ & $\begin{array}{l}\text { Náteky fosfátů na } \\
\text { vnitřní straně } \\
\text { vertikálních pórů**; } \\
\text { malé Fe/Mn konkrece*; } \\
\text { bioturbace spojená } \\
\text { s výskytem exkrementů } \\
\text { mikrofauny* }\end{array}$ & $\begin{array}{l}\text { Je nehomogenní bez } \\
\text { známek horizontálního } \\
\text { usměrnění }\end{array}$ \\
\hline Panenská 4 & A & $\mathrm{C}$ & $\begin{array}{l}\text { Meziagregátové } \\
\text { póry**; dutiny } \\
\text { nepravidelného } \\
\text { tvaru* a kanálky+ }\end{array}$ & $\begin{array}{l}\text { Qzr, Fls, slída, opákní } \\
\text { minerály, sparitický } \\
\text { karbonát a klasty } \\
\text { metabazitových hornin; } \\
\text { barva je světle hnědá; } \\
\text { Bf krystalický }\end{array}$ & $\begin{array}{l}\text { Rozložená organická } \\
\text { hmota (tečkování)* }\end{array}$ & $\begin{array}{l}\text { Bioturbace spojená } \\
\text { s výskytem exkrementů } \\
\text { mikrofauny*; sparitický } \\
\text { karbonát jako } \\
\text { pseudomorfózy po } \\
\text { kořenových buňkách+ }\end{array}$ & $\begin{array}{l}\text { Je nehomogenní bez } \\
\text { známek horizontálního } \\
\text { usměrnění, středně } \\
\text { vytříděná }\end{array}$ \\
\hline Panenská 4 & B & $\mathrm{C}$ & $\begin{array}{l}\text { Horizontální } \\
\text { póry**; dobře } \\
\text { vyvinuté } \\
\text { meziagregátové } \\
\text { póry**; dutiny } \\
\text { nepravidelného } \\
\text { tvaru* } \\
\text { a zakulacené } \\
\text { dutiny* }\end{array}$ & $\begin{array}{l}\text { Qzr, Fls, slída, opákní } \\
\text { minerály, klasty } \\
\text { metabazitových hornin } \\
\text { a fragmenty propálené } \\
\text { matrix; barva je hnědá; } \\
\text { Bf krystalický }\end{array}$ & $\begin{array}{l}\text { Rozložená organická } \\
\text { hmota (tečkování)*; } \\
\text { útržky rozložené } \\
\text { organické hmoty+; } \\
\text { mikrouhlíky+; uhlíky+; } \\
\text { skořápky vajec+; } \\
\text { fragmenty kostí+ }\end{array}$ & $\begin{array}{l}\text { Iluviační náteky, resp. } \\
\text { horizonty mikritického } \\
\text { karbonátu* a prachovité } \\
\text { akumulace ve tvaru } \\
\text { laminy*; bioturbace*; } \\
\text { stopy po lezení a s tím } \\
\text { související exkrementy } \\
\text { mikrofauny* a deplece } \\
\text { v částech matrix této } \\
\text { subfacie* }\end{array}$ & $\begin{array}{l}\text { Facie celkově variabilní } \\
\text { znatelné usměrnění; na bázi } \\
\text { tenká vrstvička spálené } \\
\text { organické hmoty } \\
\text { a mikritického karbonátu } \\
\text { z degradovaného popela; } \\
\text { podobná se objevuje znovu } \\
\text { cca v polovině aktivní } \\
\text { vrstvy; aktivní vrstva je } \\
\text { zakončena půdní krustou, } \\
\text { která vznikla jako důsledek } \\
\text { sedimentace v kaluži }\end{array}$ \\
\hline Panenská 4 & C & $\mathrm{C}$ & $\begin{array}{l}\text { Praskliny*; } \\
\text { horizontální } \\
\text { póry+; dutiny } \\
\text { nepravidelného } \\
\text { tvaru*; } \\
\text { meziagregátové } \\
\text { póry* a kanálky** }\end{array}$ & $\begin{array}{l}\text { Qzr, Fls, slída, opákní } \\
\text { minerály, fragmenty } \\
\text { propálené matrix, klasty } \\
\text { nejrůznějších hornin, } \\
\text { vápenná malta, klasty } \\
\text { redeponovaných } \\
\text { prachovitých náteků; } \\
\text { barva matrix je hnědá; } \\
\text { Bf krystalický }\end{array}$ & $\begin{array}{l}\text { Rozložená organická } \\
\text { hmota (tečkování)*; } \\
\text { útržky rozložené } \\
\text { organické hmoty+; } \\
\text { mikrouhlíky+; uhlíky+ }\end{array}$ & $\begin{array}{l}\text { Kořenová bioturbace**; } \\
\text { stopy po lezení a s tím } \\
\text { souvisejícími } \\
\text { exkrementy } \\
\text { mikrofauny*; deplece* } \\
\text { a na druhé straně } \\
\text { ćástečná impregnace } \\
\text { hydroxidy železa*; } \\
\text { sparitický karbonát* } \\
\text { a mikritický karbonátu } \\
\text { na vnitřní straně } \\
\text { kanálků+ }\end{array}$ & $\begin{array}{l}\text { Materiálově silně } \\
\text { nehomogenní bez známek } \\
\text { horizontálního usměrnění; } \\
\text { je složen z matrix } \\
\text { redeponované spraše } \\
\text { a půdy, dále pak klastů } \\
\text { hornin a redeponovaných } \\
\text { pedostrukturních struktur }\end{array}$ \\
\hline
\end{tabular}

Tab. 1. Mikromorfologický popis studovaných kontextů. Mikrostruktura (M): Ch - kanálkovitá; C - komplexní; G - granulární; P - plátovitá; Pr - prasklinová; $M$ - masivní; D - dutinová; Qzr - křemen; Fls - živec; OM - organická hmota; Bf (birefringence) - dvojlom matrix; + př́itomno v minimálním množství; * vzácně (<2\%); ** př́ležitostně (2-5\%); ** běžně $(5-10 \%) ; * * *$ často $(10-20 \%) ; * * * *$ velmi často $(>20 \%)$.

Tab. 1. Micromorphological description of studied samples. Microstructure (M): Ch-channel; C - complex; G - granular; $P$ - platy; Pr - cracky; $M$ - massive; D - vughy; Qzr - quartz; Fls - feldspar; OM - organic matter; Bf - birefringence; + occurring in the minimum amount; * rarely (<2\%); ** occasionally (2-5\%); ${ }^{* * *}$ ordinarily (5-10\%); **** often (10-20\%); ***** very often $(>20 \%)$.

\section{Diskuse}

\subsection{Lze vyčlenit specifické typy aktivních vrstev?}

1. Podlahové sendviče detekované v kontextech podlah středověkých nadzemních staveb a suterénů lze začlenit do tří hlavních skupin.

2. Aktivní vrstvy mají viditelné usměrnění predisponované depozicí sena, slámy nebo rostlinných roštů. Většinou mají polohy s usměrněnou matrix v důsledku tlaku nebo suchého zametání. Nenesou známky iluviace (Bašty 057; Biskupská 2; Biskupská 283/284; Veselá 1; Veselá 4).

3. Minerální matrix aktivních vrstev vykazuje částečné usměrnění, ale aktivní ani podložní pasivní vrstva nenesou známky iluviace. Vrstvy vznikly nášlapem. Na základě jejich matrix je možné, že povrch mohl být mechanicky upravován suchou cestou (zametání) nebo k usměrnění došlo díky pouhému tlaku v důsledku chození (Bašty 059; Biskupská 4; Orlí 75/08/05; Orlí 75/08/06 (spodní aktivní vrstva), Panenská 2 všechny tři aktivní vrstvy).

4. Aktivní vrstvy nesou známky usměrnění a vznikly pouze nášlapem. Mohou místy obsahovat i fragmenty deponovaného sena, slámy nebo rohoží. Obsahují však také množství iluviačních náteků detekovatelných v samotné aktivní vrstvě nebo v pasivní vrstvě pod ní, což poukazuje na pravděpodobnost úpravy povrchu mokrou cestou (Biskupská 1; Orlí 75/08/06 - svrchní aktivní vrstva; Orlí 75/08//07; Panenská 1; Panenská 3; Panenská 4; Veselá 2; Veselá 3). 
Pokud rozdělíme typy aktivních vrstev dle výše uvedeného tř́ídění, je zřejmé, že 1) aktivní vrstvy s depozicí organické složky byly zachyceny $\mathrm{v}$ pěti prrípadech (tř̌i $\mathrm{z}$ toho patří nadzemním domům a jeden suterénu); 2) aktivní vrstvy, které nesou známky usměrnění, nikoliv však iluviace, byly detekovány v sedmi případech (v pěti př́ípadech šlo o suterény, ve dvou o nadzemní stavby); 3) aktivní vrstvy, které vznikly nášlapem s př́padnou depozicí organické složky a jsou ovlivněny prosakujícími roztoky, byly detekovány v osmi případech (tedy tři nadzemní budovy a pět suterénů). Z uvedeného je zřejmé, že úprava pochozích aktivních vrstev není jednotná a není možné podle způsobu úpravy hodnotit vrstvu jako suterén či podlahu nadzemní budovy. Je pravděpodobné, že způsoby, jakými aktivní vrstva vznikala, budou spíše závislé na konkrétním kontextu, tzn. lokalizaci v rámci parcely a s tím souvisejícím využitím nadzemní stavby, jak se ukázalo v př́ípadě lokality Veselá (Lisá et al. 2020b).

\subsection{Typ aktivní vrstvy může reflektovat lokalizaci v rámci stavby}

Je však zřejmé, že depozice organických rohoží, případně sena a slámy byla vázána $\mathrm{v}$ rámci studovaného setu podlah většinou na nadzemní stavby. I v tomto ohledu se však dají najít výjimky. Př́íladem může být depozice sena nebo slámy v suterénu novověkého domu v Tišnově, která sloužila pravděpodobně jako vrstva zabraňující případnému promrzání (Lisá et al. 2009). Podlahové úrovně vzniklé nášlapem bez mokrého zametání byly detekovány pouze $\mathrm{v}$ suterénech a $\mathrm{v}$ jednom př́padě (Panenská 2) v nadzemní stavbě. Podobný nález byl nedávno publikován z menšího sklípku v Králově Poli, datovaného do konce 13. století (Lisá, Kolař́ík 2020). Také zde bylo poměrně dobře vyvinuto usměrnění matrix, známky po mokrém zametání však indikovány nebyly. Velkou otázkou jsou interpretace situací, kde je na povrchu zřejmé usměrnění, a v samotné aktivní vrstvě nebo pod ní jsou zřetelné iluviační náteky. Takové vrstvy mohly být pravděpodobně mechanicky upravovány, nebo k usměrnění minerální frakce došlo mechanickým tlakem při opakovaném chození. Opakovanou otázkou archeologa je, zda je možné, aby suterény byly nutně zametány. Taková možnost se zdá z dnešního pohledu celkem nepravděpodobná, nelze ji však vyloučit, protože etnografické nebo písemné prameny nejsou pro zodpovězení této otázky dostupné. V některých případech se dokonce zdá, že vrstvy vykazují i zrnitostní vytř́ídění, což může být dokladem po zametání, které bylo typické pro lidové stavby. Vznik aluviačních lamin je v každém př́ípadě dokladem o prosakující vodě. Ta mohla být součástí úpravy (mokré zametání), je však také možné, že suterény byly relativně vlhké a stála v nich voda. Tomu by odpovídaly půdní krusty zachycené v př́ípadě suterénu Panenská 1. Žádný z těchto podlahových sendvičů, kde jsou usměrněné vrstvy a iluvíální náteky, však nenese známky mechanického poškození usměrnění v důsledku pohybu po vlhkém povrchu. Je tedy stále nevyřešenou otázkou, jak tento typ vrstev interpretovat.

\subsection{Informace čitelné z pasivních vrstev}

Další faktor sledovatelný v podlahových sendvičích odráží intenzitu, př́padně i délku mechanického zatěžování v nadloží, tj. využívání podlahové vrstvy. Tato informace je patrná z přítomnosti horizontálních pórů ve vrstvě pod aktivní vrstvou. Aktivní vrstvy s intenzivním mechanickým zatěžováním byly identifikovány v př́ípadě vzorků Panenská 1, 2 a 3, Orlí 75/08/07 a ve vzorcích Veselá S1 a S3. V případě vzorků z lokalit Panenská 1,3 a Orlí 75/08/07 jde o suterény, v případě vzorků z lokalit Panenská 2 a Veselá jde o nadzemní stavby. Především v případě vzorků z lokality Veselá se jedná vždy o dvě a dvě podlahy v superpozici, a právě vzorky S1 a S3 pocházejí ze starších objektů (Lisá et al. 2020b). Je tedy otázkou, zda horizontální pukliny v př́ípadě lokality Veselá nesouvisí se zatěžováním z nadloží v důsledku stavby a využívání mladších fází objektu. Pokud bychom tento fakt přijali, je tedy prrítomnost horizontálních pórů pod aktivní vrstvou vázána výhradně na aktivní vrstvy v suterénech, př́padně na druhotně zatěžované vrstvy nadzemních staveb. V případě suterénu v Králově Poli (Lisá, Kolařík 2020) nebo suterénu v Tišnově (Lisá et al. 2009) byly horizontální póry související s mechanickým tlakem v nadloží také indikovány. Přítomnost horizontálních pórů nemusí však být obecně vázána na suterény. Při výzkumu podlah v Dolním Němčí v muzeu Na Mlýně byl indikován podlahový sendvič víceméně kontinuální podlahy vznikající od konce 18 . století téměř do poloviny 19. století (Lisá et al. 2020a; Lisá, Lisý 2019). V tomto případě šlo o intenzivní úpravy povrchu mokrým zametáním s dotací organické hmoty. Horizontální póry byly vyvinuty velmi dobře ve spodních částech cca $15 \mathrm{~cm}$ setu podlah.

V neposlední řadě je možné z podlahových horizontů vyčíst informaci o typu materiálu, který byl využit na tvorbu pasivní vrstvy. Ve většině případů je pasivní vrstvou bud'to spraš nebo redeponovaná spraš, v některých případech bylo možné indikovat pasivní vrstvu jako destrukci konstrukčního prvku rozplavením př́ípadně spálením. Pasivní vrstva, která je nevytříděná, at již obsahuje fragmenty hornin nebo nespáleného či spáleného dřeva, nemohla vzniknout v daném kontextu bez přičinění člověka.

\subsection{Paralely mezi středověkými podlahovými sety a etnografií}

Otázkou zůstává, zda je možné nalézt paralely mezi podlahovými sety zkoumanými mikromorfologicky nebo popisovanými etnograficky $\mathrm{z}$ dob nedávno minulých s těmi, které jsme schopni detekovat $\mathrm{v}$ archeologickém záznamu středověkého domu. $\mathrm{V}$ tuto chvíli je nutné přiznat, že ne. Důvodem je však především téměř mizivá základna srovnávacích studií. Mikromorfologicky byl v našem středoevropském kontextu zkoumán pouze jeden novověký dům, a to dům v Dolním Němčí, který je součástí muzea Na Mlýně. Podlahový set byl typický cca $1 \mathrm{~cm}$ mocnými laminami. Ty však v žádném př́ípadě neodrážely postupné inovace, ale spíše způsoby či intenzitu každotýdenních úprav pochozího povrchu. Ze středoevropské etnografie toho o vytváření a úpravách podlah víme stále zoufale málo. Jsou doklady o tom, že pasivní vrstvy byly cíleně vytvářeny ze směsi exkrementů a spraše. Tatáž směs byla nanášena na povrch podlahy v př́padě jejích oprav. Tyto praktiky však v námi zkoumaných situacích zachyceny nebyly. Pokud bychom sáhli po středověkých paralelách v Evropě, je možné najít př́ílady akumulace rostlinných rohoží ve špitále ve středověkém Londýně (Macphail, Goldberg 2018). Další paralely téměř neexistují, nebo je jejich detailní ověření jen těžko dostupné, vyjma znalostí o vytváření konstrukčních vrstev podlah z přeneseného geologického podloží (napřs. spraše) či jinak zpracované místní hlíny (viz nap̌r. Novotný 2019).

\subsection{Nakolik se odlišuje informace z terénního výzkumu od té získané mikromorfologickým pozorováním?}

Jak vyplývá z výše uvedených výsledků, ne vždy se jednotlivé mikromorfologicky popsané mikrovrstvy projevují makroskopicky při terénním pozorování (tab. 2). Na druhou stranu makroskopicky popsaná vrstva nemusí být nutně primárně deponovaný sediment, může jít o postsedimentární změnu, která se makroskopicky projeví např́íklad větší tuhostí nebo barevnou změnou kontextu. Nejčastěji nedojde vzhledem $\mathrm{k}$ velikosti 
mikrovrstev k rozpoznání jejich počtu, případně je počet proměnlivý v ploše, proto je vrstva označována jako jeden kontext; potom je nutné jej detailně popsat. Právě přítomnost mikrovrstev, které nelze detekovat makrostratigraficky, může mít velmi důležitý interpretační potenciál. V tab. 1 je shrnuto porovnání makroskopického popisu a předpokládané interpretace ve vztahu k mikromorfologickému popisu, na kterém je následně založena finální interpretace jednotlivých kontextů. Jak je zřejmé, v některých případech tyto popisy víceméně souhlasí, jen došlo ke zpřesnění interpretace, $\mathrm{v}$ některých př́padech však mikromorfologicky bylo detekováno více horizontů, které interpretaci celkového setu zpřesňují.

\begin{tabular}{lll}
\hline Lokalita & Terénní popis a interpretace & Mikromorfologická interpretace \\
\hline $\begin{array}{ll}\text { Bašty 2-4, parcela č. 351, } \\
\text { vzorky A20/1 a A20/2 (s.s.j. 057) }\end{array}$ & $\begin{array}{l}\text { Vzorek byl odebrán z podlahové úrovně suterénu. } \\
\text { Makroskopicky bylo možné rozlišit na dvě uloženiny. }\end{array}$ & $\begin{array}{l}\text { Mikromorfologicky zde mohou být vyčleněny minimálně tř̌i } \\
\text { Spodní byla tvořena tmavě šedou jílovitou hlínou s nahodilými a }\end{array}$ \\
& $\begin{array}{l}\text { uhlíky a drobnými zlomky žluté písčité hlíny (s.j. 234), horní } \\
\text { sestávala ze světle šedé jílovité hlíny s nahodilýmentámi uhlíky }\end{array}$ & \\
& a četnými procesy.
\end{tabular}

Bašty 2-4, parcela č. 351, vzorky A20/4 a A20/5 (s.s.j. 059)

Vzorek se soustředil na odběr vrstvičky, která zřejmě vznikla komunikačními procesy na dně sklepa. Dominantní složkou byla tmavá hnědošedá plastická hlína (s.j. 318). Pod ní se nacházelo sprašové podloží, nad ní zásypové vrstvy sklepa.

Biskupská 7, parcela č. 381, vzorek č. 1 (s.j. 163-162-161)

\section{Vzorek byl odebrán z nadzemní části stavby. Makroskopicky} v sobě zahrnul tři uloženiny. Bázi (s.j. 163) a svrchní (s.j. 161) část tvořila okrová plastická hlína, přičemž mohlo jít o hmotu nevypálené mazanice. Měly mocnost okolo $5 \mathrm{~cm}$ a byly interpretovány jako konstrukční (sanační) vrstvičky podlahy. Mezi nimi se nacházela vrstvička šedé plastické hlíny (s.j. 162) o mocnosti $1 \mathrm{~cm}$, která zřejmě vznikla jako výsledek komunikačních procesů a úprav podlahy.

Biskupská 7, parcela č. 381, vzorek č. 2 (s.j. 149-144)

\section{Vzorek byl odebrán z povrchové úpravy dvora. Obsahoval} dvě vrstvy. První z nich mohla vzniknout v důsledku komunikace a úpravy povrchu dvora, druhá jako kumulace odpadu nebo planýrka dřevohliněné stavby.
Mikromorfologicky byla vyčleněna jedna homogenní, ale nevytrríděná vrstva vzniklá nášlapem.

Mikromorfologicky bylo vyčleněno stejné množství vrstev, přičemž byl potvrzen makroskopický předpoklad vzniku aktivní vrstvy a doloženo intenzivní zatěžování, které pozměnilo pasivní vrstvu pod aktivní vrstvou.
Mikromorfologicky byly zachyceny čtyři vrstvy, a to dvě pasivní a dvě aktivní. Je však otázka, zda vůbec jde o podlahovou vrstvu. Složení těchto vrstev odpovídá depozici kuchyňského odpadu, včetně popela. V př́ípadě svrchní subfacie C je usměrnění zřetelnější, v nejvrchnější části je dokonce vrstvička artikulovaných fytolitů. Její povrch je však mírně zvlněný, a není vyloučeno, že se jedná o venkovní pochozí horizont.

Mikromorfologie přinesla stejné výstupy s tím, že mezi pasivní a aktivní vrstvou vznikla tzv. reaktivní vrstva tvořená impregnacemi fosfátů z rozkládajících se kostí. Žorek byl odebrán z nadzemní části stavby. Zahr tři uloženiny. Báze je interpretována jako konstrukční vrstva podlahy, původem snad z planýrky dřevohliněné konstrukce. Na ní byla uložena přibližně $1 \mathrm{~cm}$ silná vrstvička okrově šedé plastické hlíny (s.j. 226), která se zřejmě utvořila v důsledku komunikačních procesů a úpravy podlahy. Následovala vrstva šedé písčité hlíny s četnými kamínky a kameny, určená jako navážka či planýrka.

Biskupská 7, parcela č. 381, Vzorek s.j. 266-249

Vzorek byl odebrán z nadzemní části stavby nebo jejích planýrek. Zahrnul v sobě dvě uloženiny. Bázi tvořila světle rezavohnědá až rezavookrová plastická hlína (s.j. 266), svrchní část šedookrová plastická hlína se zlomky šedé plastické hlíny (s.j. 249). První byla interpretována jako planýrka konstrukce dřevohliněné stavby s.s.j. 020, druhá jako planýrka stavby s.s.j. 021, přičemž první z nich vytvořila základovou vrstvu podlahy druhé stavby. Biskupská 7, parcela č. 381,
vzorek s.j. 283-284
Vzorek byl odebrán z podlahové úrovně suterénu. Makroskopicky v sobě vzorek zahrnul dvě uloženiny z podlahové úrovně suterénu dřevohliněné stavby (s. s.j. 024). Bázi tvořila šedá plastická / písčitá hlína s nahodilými uhlíky, kamínky a zlomky vypálené mazanice (s.j. 283), svrchní část světle šedá plastická hlína s nahodilými uhlíky (s.j. 284).

Vzorek byl odebrán z podlahové úrovně suterénu 9. Tvořila ji vrstvička šedé plastické hlíny s nahodilým výskytem uhlíků a zlomků vypálené mazanice. Na ní ležely zásypy suterénu.
Mikromorfologické pozorování přineslo zajímavé zjištění, které souvisí s průběžností vrstev v ploše. Vzorek byl totiž popsán jako homogenní, i když nevytříděný, tj. žádná aktivni vrstva zde zachycena nebyla. Je to pravděpodobně dáno tím, že v prostoru odběru došlo $\mathrm{k}$ jejímu ztenčení do té míry, že nebyla výbrusem zastižena.
Panenská 1, parcela č. 501/1 vzorek 1
Mikromorfologicky je zřejmé, že podlahový set je silně ovlivněn postdepozičně, pravděpodobně ve spojení s nějakou výrobou. Samotná pasivní vrstva je starší destrukce tvořená nevytříděným sedimentem. Aktivní vrstva je tvořena nejméně třemi mikrovrstvami horizontálně uložené organické hmoty, které se projevují akumulací artikulovaných fytolitů. Vše postdepozičně silně ovlivněno.

V rámci vzorku lze obecně vyčlenit dvě pasivní a jednu aktivní vrstvu. Spodní pasivní vrstva (subfacie A) je tvořena jen mírně kontaminovanou redeponovanou spraší ve svrchní části silně ovlivněnou tlakem z nadloží. Aktivní vrstva je značně nehomogenní, vykazuje známky opakovaného usměrňování a zároveň má množství postsedimentárních struktur typických pro pronikající roztoky. Jde tedy pravděpodobně o podlahový horizont udržovaný mokrým zametáním nebo intenzivním popocházením s fázemi, kdy v suterénu stála voda. 


\section{Lokalita}

Panenská 1, parcela č. 501/1, vzorek 2
Terénní popis a interpretace

Vzorek byl odebrán z podlahových úrovní nadzemní části dřevohliněné stavby. Uloženy byly na vrstvě redeponované spraše. Její povrch překryla tenká hnědošedá vrstvička (s.j. 3129), patrně vzniklá nášlapem, následovala (sanační?) vrstva okrové plastické hlíny (s.j. 3128). Povrch opět překryla tenká šedá vrstvička (s.j. 3127). Dále byla podlaha navýšena prostřednictvím uloženiny s.j. 2378 sestávající především z okrové plastické hlíny. Na ní byla přítomna výrazně popelovitá vrstvička s.j. 2377, následovala podlahová vrstvička s.j. 2374, tvořená př̀edevším šedou plastickou hlínou. Překryla ji vrstva šedookrové plastické hlíny (s.j. 2375), snad navýšení podlahy či planýrka konstrukce stavby.

Panenská 1, parcela č. 501/1, vzorek 3

Vzorek byl odebrán z podlahové úrovně suterénu 7. Při výzkumu byla rozdělena na tři základní jednotky, celková mocnost dosahovala $10 \mathrm{~cm}$. Přímo na dně suterénu ležela vrstvička šedé plastické hlíny (s.j. 2135), následovala vrstvička okrové plastické hlíny (s.j. 2134) a dále vrstvička s.j. 2131, která měla obdobný charakter jako s.j. 2135. Na ní již byly uloženy zásypy suterénu.
Mikromorfologická interpretace

V rámci vzorku 2 bylo vyčleněno celkem osm mikrofacií reprezentovaných čtyřmi pasivními a čtyřmi aktivními vrstvami. Většina pasivních vrstev je tvořena redeponovanou spraší minimálně kontaminovanou artefakty a má známky kompakce. Aktivní vrstvy jsou tvořeny většinou běžným odpadem, nejsvrchnější je propálena, k propálení došlo na místě.

Orlí 75/08/05

Vzorek byl odebrán z podlahové úrovně suterénu s.s.j. 12-13. Podlahová úroveň byla tvořena tenkou vrstvičkou šedé plastické hlíny s nahodilými uhlíky (s.j. 368), která překrývala dno výkopu a zřejmě vznikla v důsledku komunikačních procesů. Na ní ležela vrstvička okrové plastické hlíny (s.j. 367), kterou lze snad interpretovat jako následnou úpravu podlahy.

V rámci vzorku 3 byly vyčleněny celkem tři subfacie. Spodní a svrchní reprezentuje pasivní vrstvu, uprostřed je aktivní vrstva. Samotná aktivní vrstva obsahuje usměrněnou matrix, ale také množství iluviačních náteků. Jednotlivé laminky mají různý původ - karbonátové jsou pravděpodobně redeponovaný popel, fosfatické pocházejí z rozkladu kostí. Vznik iluviačních náteků reflektuje př́tomnost vody.

ový set je tvoren dvěma konstrukčnimi pasivním vrstvami, přičemž svrchní je silně ovlivněna stagnující vodou. Na nich akumulovaná aktivní vrstva podlahového setu je potom tvořena běžným kuchyňským odpadem spolu s minerální matrix.

Orlí 75/08/06; 75/08/07

Vzorek byl odebrán z podlahové úrovně suterénu s.s.j. 12-13. Vrstva okrové plastické hlíny s mezivrstvičkami šedé plastické hlíny (s.j. 384) byla určena jako komunikační a měla by souviset s druhou fází suterénu se zvýšenou úrovní podlahy (s.j. 013). Z dolní části vrstvy byl odebrán vzorek 75/08/06, z horní vzorek 75/08/07.
Ve vzorku Orlí 75/08/06 bylo možné vyčlenit celkem pět subfacií reprezentujících (1) spraš in situ, (2) vrstvu kuchyňského odpadu, která je částečně usměrněna a na bázi má vrstvičku nespáleného dřeva. Na povrchu usměrněné vrstvy byly detekovány zbytky exkrementu býložravců nebo všežravců, jde však o ojedinělý nález. Aktivní vrstva je převrstvena (3) další pasivní vrstvou, kterou tvoří redeponovaná spraš, na kterou nasedá (4) krátkodobý nášlap. Poslední (5) pasivní vrstva (nebo zásyp) je tvořen redeponovanou spraší.

Ve vzorku 75/08/07 byla na bázi zachycena pasivní vrstva tvořená spraší, na které je deponován kuchyňský odpad se známkami mokrého zametání. Celý set je překryt další pasivní vrstvou tvořenou redeponovanou spraší.

Tab. 2. Rozdíly mezi terénní a mikromorfologicku interpretací odebraných podlahových setů.

Tab. 2. Differences between the field and micromorphological interpretations of floor sandwiches.

\section{Závěr}

Předkládaná studie porovnává formační procesy vzniku podlahových sendvičů stř̌edověkých domů z konce 13. a začátku 14. století na území města Brna. Do studie byly zahrnuty podlahové sendviče suterénů i nadzemních staveb. Celkem bylo studováno 11 podlahových sendvičů suterénů a osm podlahových sendvičů nadzemních staveb. Do této části byly zahrnuty již publikované sendviče nadzemních staveb z lokality Veselá. Způsoby úpravy povrchu aktivních vrstev a typ materiálu pasivních vrstev nejsou zcela jednotné ani mezi suterény, ani mezi nadzemními stavbami. Lze však konstatovat, že v př́padě města Brna jsou pasivní vrstvy podlahových sendvičů vytvářeny téměř výhradně ze spraše nebo sprašového materiálu, který byl v minulosti součástí nějakého stavebního prvku, respektive sekundárními zásypy, které jsou výsledkem postdepozičních procesů. Aktivní vrstvy lze rozdělit do tř́ základních typů. Ty, které jsou tvořeny převážně akumulací organických rohoží nebo sena či slámy a nejsou promývány vodou. Tyto typy povrchů jsou většinou vázány na nadzemní objekty. Druhým typem aktivní vrstvy jsou ty, které vznikaly nášlapem a nesou známky alespoň částečného usměrnění, př́ípadně jsou pasivní vrstvy pod těmito nášlapy tvořeny horizontálními póry, což svědčí o vysokém mechanickém tlaku.
Tyto typy aktivních podlah jsou většinou vázány na suché suterény. Poslední velkou skupinou aktivních vrstev, která se prolíná např́íc suterény i nadzemními objekty, jsou aktivní vrstvy, tvořené alespoň částečně usměrněnou minerální frakcí s intenzivní př́tomností náteků dokumentujících protékající roztoky (tekutiny?). Tyto typy aktivních vrstev vznikly pravděpodobně v důsledku mokrého zametání nebo suchého zametání, případně mechanického usměrnění sešlapáním a vystavením krátkodobé přítomnosti stagnující vody. Poslední otázkou, která je v článku diskutována, je možnost porovnávání etnografických paralel se středověkými kontexty. Vzhledem k malému množství analyzovaných dat je toto srovnání prozatím velmi komplikované, nicméně se zdá, že takové paralely téměř neexistují. V budoucnu se proto zaměříme více i na odběr vzorků z oblasti vernakulární architektury a experimentu. Celkově lze říct, že základní závěry mikromorfologických analýz potvrzují archeologická makroskopická pozorování v terénu, kde jsou zpravidla správně rozlišovány podlahové vrstvy aktivní (obecně nazývané jako nášlapy) i pasivní (obecně zvané jako dorovnávky či podlahy). Svým detailním rozborem však jejich interpretaci významně rozšiřují a poskytují netušený vhled do jejich vzniku a údržby. Dosavadní mikromorfologické rozbory prozatím přesvědčivě neodpověděly 
na zásadní otázku, zda některé suterény nemohly být i obytné, což je věc již po několik uplynulých desetiletí obecně diskutovaná a známá jako problematika tzv. zemnic. Prozatím se zdá, že absence více fází konstrukčních vrstev u suterénů, oproti dokumentovaným podlahovým souvrstvím nadzemních staveb, stejně jako nepř́tomnost topeništ zahloubených staveb tuto možnost v Brně prozatím spíše vylučují. Na komplexní závěry o podlahových souvrstvích a jejich odraz při interpretaci funkce jednotlivých staveb si však musíme počkat až po vyhodnocení dalších desítek odebraných vzorků. Jsme si samozřejmě vědomi limitů, které přineslo vyhodnocení poměrně malého, statisticky nevýznamného souboru vzorků prezentovaného v rámci této studie, proto bude naší primární snahou postupná analýza všech již odebraných sendvičů. V rámci terénních archeologických výzkumů středověkých měst a vesnic také bude v dalších letech pokračovat odebírání nových vzorků. Zejména pokud se objeví př́ležitost komplexního studia nějakého rozsáhlejšího zahloubeného či nadzemního obytného či hospodářského objektu, $\mathrm{v}$ takovém př́padě budou vzorky odebrány z více míst podlahového souvrství jednoho objektu a vzájemně srovnány. Tento přístup jsme prozatím neuplatnili; jeho použitím bychom mohli v budoucnosti rekonstruovat mnohem detailněji formační procesy $\mathrm{v}$ rámci jedné relativně uzavřené komunity, a také specifikovat rozdílné využití prostoru v rámci jednotlivých staveb.

\section{Poděkování}

Předkládaná studie vznikla jako jeden z výstupů grantového projektu Grantové agentury ČR „Proměna městského domu ve 13. století“ (GAČR reg. č. 17-23836S) a byla dále podpořena interním programem Geologického ústavu AV ČR, v. v. i., č. RVO 67985831.

\section{Poznámky}

1 S.s.j. - svazek stratigrafických jednotek. Podle užité metodiky zahrnuje jeden svazek aktivity, které spolu souvisejí a často vytvářejí vyšší celek. Pro jednotlivé aktivity se užívá termín stratigrafická jednotka (zkratka s.j.).

\section{Literatura}

Beran, V., Hajnalová, M., Kos, P., Lisá, L., Parma, D. 2013: Geoarcheologický výzkum raně středověké kovárny z Modřic u Brna. Živá archeologie. (Re)konstrukce a experiment $v$ archeologii 15(2), 25-31.

Boivin, N. 2000: Life rhythms and floor sequences: Excavating time in rural Rajasthan and Neolithic Çatalhöyük. World Archaeology 31(3), 367-388.

Borský, P., Merta, D., Peška, M., Zůbek, A. 2016: Bývalý kanovnický dům Biskupská 7 v Brně. In: Dějiny staveb. Sborník př́spěvkư z konference Dějiny staveb 2016. Plzeň: Petr Mikota, 209-219.

Brachmann, H., Klápště, J. (eds.) 1996: Hausbau und Raumstruktur früher Städte in Ostmitteleuropa. Památky archeologické, Supplementum 6. Praha: Archeologický ústav AV ČR, Praha.

Černá, L., Dejmal, M., Holub, P., Kolařík, V., Merta, D., Peška, M., Sedláčková, L., Zbranek, H., Zůbek, A. 2012: Brno (okr. Brno-město). Přehled výzkumů 53(2), 100-136. Dostupné také z: https://www.arub.cz/prehled-vydanych-cisel/ PV53_2_stredovek_a_novovek.pdf.

Černá, L., Holub, P., Kolařík, V., Merta, D., Peška, M., Sedláčková, L., Zůbek, A. 2014: Brno (okr. Brno-město). Přehled výzkumů 55(2), 171-205. Dostupné také z: https://www.arub.cz/ prehled-vydanych-cisel/PV55_2_stredovek_a_novovek.pdf.

Černá, L., Merta, D., Zůbek, A. 2015: Nálezová zpráva o provedení záchranného archeologického výzkumu při stavbě Brno, Biskupská 7, nová př́stavba ve dvorní části. Rkp. nálezové zprávy, č. j. MTX201602581. [cit. 2021-12-06]. Uloženo: Archiv nálezových zpráv Archeologického ústavu AV ČR, Brno, v. v. i. Dostupné také z: Digitální archiv Archeologické mapy České republiky https://digiarchiv.aiscr.cz/id/M-TX-201602581.

Dejmal, M., Peška, M. 2010: Nálezová zpráva o provedení záchranného archeologického výzkumu v prostoru dvorku pri rekonstrukci objektu Bašty 2 a 4 - „Padowetz“v Brně. Rkp. nálezové zprávy č. j. 6/10. Uloženo: archiv Archaia Brno z. ú.

Donat, P. 2000: Zum städtischen Hausbau des 13. Jhs. im östlichen Mitteleuropa. Slavia antiqua XLI, 129-172.

Flodr, M. (ed.) 2005: Pamětní kniha města Brna z let 1343-1376 (1379). Brno: Matice moravská.

Gé, T., Courty, M. A., Matthews, W., Wattez, J. 1993: Sedimentary formationprocesses of occupation deposits. In: P. Goldberg, D. T. Nash, M. D. Petraglia (eds.): Formation Processes in Archaeological Context. Monographs in World Archaeology 17. Madison: Prehistory Press, 149-163.

Gläser, M. (ed.) 2001: Lübecker Kolloquium zur Stadtarchäologie im Hanseraum. Band III. Der Hausbau. Lübeck: Verlag Schmidt-Römhild.

Goldberg, P., Macphail, R. I. 2006: Practical and Theoretical Geoarchaeology. Oxford: Blackwell Publishing, 455.

Holub, P. 2012: Brno, Orlí 19/21. Hudebně dramatická laboratoř JAMU. Rkp. nálezové zprávy, č. j. MTX201401554. [cit. 2021-12-06]. Uloženo: Archiv nálezových zpráv Archeologického ústavu AV ČR, Brno, v. v. i. Dostupné také z: Digitální archiv Archeologické mapy České republiky https://digiarchiv.aiscr.cz/id/M-TX-201401554.

Holub, P., Kolařík, V., Merta, D., Peška, M., Polánka, P., Sedláčková, L., Zapletalová, D., Zůbek, A. 2006: Brno (okr. Brno-město). Přrehled výzkumů 47, 170-226. Dostupné také z: https://www.arub.cz/wp-content/uploads/ pv_47_2005_stredovek_a_novovek.pdf.

Holub, P., Kolařík, V., Merta, D., Peška, M., Polánka, P., Sedláčková, L., Zapletalová, D., Zůbek, A. 2007: Brno (okr. Brno-město). Přehled výzkumů 48, 410-461. Dostupné také z: https://www.arub.cz/wp-content/uploads/ pv_48_2006_stredovek_a_novovek.pdf.

Holub, P., Kolařík, V., Merta, D., Peška, M., Polánka, P., Sedláčková, L., Zapletalová, D., Zůbek, A. 2008: Brno (okr. Brno-město). Přrehled výzkumů 49, 356-393. Dostupné také z: https://www.arub.cz/wp-content/uploads/ pv_49_2007_stredovek_a_novovek.pdf.

Holub, P., Kolařík, V., Merta, D., Peška, M., Sedláčková, L., Zapletalová, D., Zůbek, A. 2010: Brno (okr. Brno-město). Přehled výzkumů 51, 395-432. Dostupné také z: https://www.arub.cz/ prehled-vydanych-cisel/PV51_stredovek_a_novovek.pdf.

Holub, P., Kolařík, P., Merta, D., Peška, M., Zapletalová, D., Zůbek, A. 2005: Ke stavu poznání nezděné měštanské architektury vrcholně středověkého Brna. In: D. Merta, M. Peška (eds.): Forum urbes medii aevi 2. Sborník př́spěvků z konference FUMA konané 16. - 18. 3. 2003. Brno: Archaia, 44-101.

Holub, P., Kolařík, P., Merta, D., Peška, M., Zůbek, A. 2013a: Bürgerliche Architektur des hochmittelalterlichen Brno/Brünn. In: Y. Hoffmann, U. Richter (Hrsg.): Die Frühgeschichte Freibergs im überregionalen Vergleich. Städtische Frühgeschichte-Bergbaufrüher Hausbau. Halle: Mitteldeutscher Verlag, 457-471.

Holub, P., Kolařík, V., Merta, D., Peška, M., Zůbek, A. 2015: Medieval Brick Architecture in Brno in the Context of South Moravia. In: Z. Měřínský (ed.): Forum urbes medii aevi IX(1-2). Bricks and Building Ceramics in Medieval and Modern Urban Architecture of Central Europe. Brno: Archaia Brno o. p. s., 310-337.

Holub, P., Merta, D., Peška, M., Procházka, R. 2013b: Dům a parcela. In: L. Jan (ed.): Dějiny Brna 2. Středověké město. Brno: Archiv města Brna, 812-847. 
Holub, P., Merta, D., Peška, M., Zapletalová, D., Zůbek, A. 2003: K otázce topeništ v dřevohliněných domech ze 13. století v Brně, ...aneb proč nevěříme na zemnice. In: L. Kracíková (red.): Sborník př́spěvkĩ z I. konference stavebně historického pri̊zkumu, 4.-6. června 2002 na zámku v Zahrádkách u České Lípy. Vývoj a funkce topenište. Svorník 1/2003. Praha: Unicornis, 75-84.

Jarošová, M., Lisá, L., Přichystal, A., Parma, D., Petr, L., Kos, P. 2010: Geoarcheologický výzkum halštatské zemnice v Modřicích u Brna. Geologické výzkumy na Moravě a ve Slezsku 17(1-2), 39-46.

Karkanas, P. 2006: Late Neolithic household activities in marginal areas: the micromorphological evidence from the Kouveleiki caves, Peloponnese, Grece. Journal of Archaeological Science 33, 1628-1641.

Karkanas, P., Goldberg, P. 2019: Reconstructing Archaeological Sites; Understanding the Geoarchaeological Matrix. Oxford: Wiley Blackwell.

Klápště, J. (ed.) 2002: Ruralia IV. The rural house. From the migration period to the oldest still standing buildings. Kongress vom 08. - 13. September 2001 at Bederkesa, Lower Saxony, Evangelische Heimvolkshochschule. Památky archeologické, Supplementum 15. Prague: Institute of Archaeology, Academy of Sciences of the Czech Republic.

Küntzel, T. 2010: Die Stadtwüstung Nienover im Solling: Auswertung der Befunde zur Stadttopographie, Hausbau und Stadtbefestigung im 13. Jahrhundert. Rahden/Westf.: Marie Leidorf.

Lisá, L., Kočár, P., Bajer, A., Kočárová, R., Syrová, Z., Syrový, J., Porubčanová, M., Lisý, P., Peška, M. 2020a: The Floor - a voice of human lifeways. A geoethnographical study of historical and recent floors at Dolní Němčí Mill, Czech Republic [online]. Archaeological and Anthropological Sciences 12(115), 1-16. [cit. 2021-09-12]. Dostupné z: https://doi.org/10.1007/ s12520-020-01060-y.

Lisá, L., Kolař́ík, V. 2020: Dokáže mikromorfologie v archeologickém kontextu odpovědět na využití zahloubených prostor ve středověké vesnici? Př́íladová studie Brno-Královo pole. Archaeologia historica 45(2), 925-940. Dostupné také z: http://hdl.handle.net/11222.digilib/143435.

Lisá, L., Kolařík, V., Bajer, A. 2009: The geoarchaeological and micromorphological reconstruction of medieval food store room floor layers; the case study from Tišnov, Czech Republic. In: H. Thiemeyer (ed.): Archaeological Soil Micromorphology. Contributions to the Archaeological Soil Micromorphology Working Group Meeting 3rd to 5th April 2008. Frankfurter Geowissenschaftliche Arbeiten, Serie D, Band 30. Frankfurt am Main: Fachbereich Geowissenschaften, Geographie Johann Wolfgang Goethe-Universität, 71-80.

Lisá, L., Lisý, P. 2019: Podlaha jako experiment aneb vhled do životního rytmu našich př̀dků. Živá archeologie. (Re)konstrukce a experiment $v$ archeologii $21,3-7$.

Lisá, L., Peška, M., Merta, D., Gregor, M. 2017: Maintenance of Underground Granaries in Medieval Towns; Case Study from Padowetz, Brno, Czech Republic. Interdisciplinaria Archaeologica. Natural Sciences in Archaeology VIII(2), 157-165.

Lisá, L., Staněk, P., Zůbek, A., Nejman, L. 2020b: Floor Maintenance as a Possible Cultural Behavioural Status? Preliminary Interpretations of Floor Formation Processes from Medieval Brno, Czech Republic. Interdisciplinaria Archaeologica. Natural Sciences in Archaeology XI(1), 63-72.

Loskotová, I., Procházka, R. 1995: Brněnské zemnice (Příspěvek $\mathrm{k}$ vývoji městské zástavby 13 . století). Brno v minulosti a dnes XIII, 112-149.

Macphail, R. I. 1990: Soil history and micromorphology. In: M. Bell (ed.): Brean Down Excavations 1983-1987. English Heritage Archaeological Report 15. London: English Heritage, 187-196.
Macphail, R. I., Cruise, G. M., Allen, M. J., Linderholm, J., Reynolds, P. 2004: Archaeological soil and pollen analysis of experimental floor deposits; with special reference to Butser Ancient Farm, Hampshire, UK. Journal of Archaeological Science 31, 175-191.

Macphail, R. I., Goldberg, P. 2018: Applied Soils and Micromorphology in Archaeology. Cambridge Manuals in Archaeology. Cambridge: Cambridge University Press.

Matthews, W. 2005: Lifecycle and lifecourse of buildings. In: I. Hodder (ed.): Çatalhöyük Perspectives. Reports from 1995-1999 seasons bymembers of the Çatalhöyük team. Cambridge: McDonald Institute Monographs and British School of Ankara, 125-149.

Mendl, B. (ed.) 1935: Knihy počtů města Brna z let 1343-1365. Brno: Historická komise při Matici moravské a Československého státního ústavu historického.

Merta, D., Peška, M., Zůbek, A. 2016: Stř̌edověká pyrotechnologická zařízení z parcely domu Biskupská 7 v Brně. Archeologia technica 27, 55-61. Dostupné také z: http://archeologiatechnica.cz/27_at.

Milek, K. B. 2012: Floor formation processes and the interpretation of site aktivity areas: An ethnoarchaeological study of turf buildings at Thverá, northeast Iceland. Journal of Anthropological Archaeology 31, 119-137.

Novotný, M. 2019: Metodika NÚLK 01/2020. Konstrukce hliněného mlatu. Rkp. Národní ústav lidové kultury 2020 [online]. [cit. 2021-09-12]. Dostupné z: https://www.nulk.cz/wp-content/ uploads/2020/12/NULK_2020_hlineny_mlat_metodika.pdf.

Piekalski, J. 2004: Wczesne domy mieszczan w Europie Środkowej. Geneza, funkcja, forma. Wroclaw: Wydawnictwo Uniwersytetu Wroclawskiego.

Procházka, R. 1996: Zur Frage der ältesten Bebauung in den südmährischen Städten. In: H. Brachmann, J. Klápště (eds.) 1996: Hausbau und Raumstruktur früher Städte in Ostmitteleuropa. Památky archeologické, Supplementum 6. Praha: Archeologický ústav, 120-141.

Procházka, R. 2000: Zrod stř̌edověkého města na př́ikladu Brna (K otázce odrazu společenské změny v archeologických pramenech). In: M. Ježek, J. Klápště (eds.): Brno a jeho region. Mediaevalia archaeologica 2. Praha: Archeologický ústav AV ČR Praha, 7-158.

Procházka, R., Kolař́ík, V., Zůbek, A. 2013: Předměstí. In: L. Jan (ed.): Dějiny Brna 2. Středověké město. Brno: Archiv města Brna, 568-600.

Procházka, R., Zůbek, A. 2012: Výpověd’ archeologických pramenů o prostorovém vývoji jihovýchodní části Brna ve 12.-15. století na př́kladu parcely někdejšího domu Josefská 7. Archaeologia historica 37, 189-208. Dostupné také z: http://hdl.handle.net/11222.digilib/128250.

Rębkowski, M. 2001: Pierwsze lokacje miast w księstwie zachodniopomorskim. Przemiany przestrzenne $i$ kulturowe. Kotobrzeg: Instytut Archeologii i Etnologii Polskiej Akademii Nauk.

Schneider, M. (ed.) 2012: Holzbau in Mittelalter und Neuzeit. Mitteilungen der der Deutschen Gesellschaft für Archäologie des Mittelalters und der Neuzeit 24. Paderborn. Deutsche Gesellschaft für Archäologie des Mittelalters und der Neuzeit.

Stoops, G. 2003: Guidelines for Analysis and Description of Soil and Regolith Thin Sections. Madison: Soil Science Society of America.

Vičar, O. 1965: Místopis Brna v polovici 14. století (Prostor uvnitř městských hradeb). Brno v minulosti a dnes VII, 242-283.

Vičar, O. 1971: Jak vypadaly měštanské domy v Brně v polovici 14. století. Monumentorum tutela - Ochrana pamiatok 7, 57-83.

Zapletalová, D., Hložek, M. 2010: Vážky z Polní ulice na Starém Brně. Archeologické rozhledy LXII(1), 137-149. Dostupné také z: https://bit.ly/3yf2NuM. 
Zůbek, A. 2018: Archeologické projevy středověké a raně novověké nezděné zástavby na parcelách někdejších domů č. 6 a 8 na Vídeňské ulici v Brně. Archaeologia historica 43(1), 65-95. Dostupné také z: http://hdl.handle.net/11222.digilib/138123.

Zůbek, A. 2019: Archeologické projevy středověké a raně novověké zástavby první předměstské čtvrti v Brně. Archaeologia historica 44(1), 289-311. Dostupné také z: http://hdl.handle.net/11222.digilib/141304.

\section{Summary}

Non-masonry timber and earth architecture is a crucial topic of medieval Brno archaeology. Buildings constructed with timber and earth had their heyday between the foundation of the town and the mid-14th century. They are primarily represented by floor sets of basements together with archaeological findings and the floor sets or the parts of above-ground structures. In the first century after the foundation of the town, the built-up area was spatially unstable and highly varied in terms of layout. The mass replacement of most timber and earth buildings apparently took place during the first half of the 14th century. Buildings with a masonry core already dominated in Brno in the pre-Hussite period. Erstwhile non-masonry buildings are mostly represented today by the sunken parts uncovered by archaeological excavations. Besides the unique small dug and driven cellars, they include non-masonry basements, which are the most distinct and frequent evidence of timber and earth constructions of medieval Brno. Sunken spaces, usually with a rectangular or square layout, served as cellars in houses and buildings with a farming and production function. Their walls were reinforced by wooden structures and they were accessed through a set-forward entrance staircase or an entrance isthmus. The location of basements on the land plots varies. We still lack convincing evidence of their above-ground parts. During numerous rescue excavations over the past 13 years, a team of archaeologists from the Archaia Brno institute, together with Lenka Lisá of the Institute of Geology of the Czech Academy of Sciences, took about 200 micromorphological samples from the are of Brno centre. This was to acquire information about the use and maintenance of timber and earth buildings, which is also reflected in the form of the documented floor sets. Samples of floors from timber and earth buildings taken for micromorphological analysis might help us in the future to find differences between individual buildings on the plot and specify their function. On the example of five sites incorporating 24 samples from 11 timber and earth buildings from the historical core of Brno (Bašty 2-4, Biskupská 7, Panenská 1, Orlí 19, Veselá), we demonstrate the type of information that can be acquired from these previously overlooked types of sedimentary records. All the samples taken were vacuum dried and impregnated using Polylite 2000 resin. After curing, which usually takes six weeks, the samples were sliced and processed into thin sections covered by glass. It was always apparent from the archaeological context whether the structures in question were the above or below-ground parts of the houses and in what parts of the plots the buildings were situated. The samples were studied using the method of micromorphology in an archaeological context.
The origin and treatment of the active layers were assessed within the present study: their interpretation was mutually compared and divided into three types. The first consists predominantly of accumulations of organic matting, hay or straw and are not washed with water. These types of surfaces are mostly found in above-ground structures. The second type of active layers came into existence by stepping and bear marks of at least partial direction; the passive layers under these stepping layers may consist of horizontal pores, testifying to high mechanical pressure. These types of active floors are mostly bound to dry basements. The last major group of layers, which occurs throughout basements and above-ground structures, are active layers consisting of at least a partially directed mineral fraction with an intensive presence of the results of leaks into by flowing solutions (fluids?). These types of active layers can be interpreted as caused by wet sweeping or, possibly, mechanical direction by stepping and exposure to the short-term presence of stagnant water. In general, micromorphological observation of the studied features enabled us to distinguish the floor stratigraphy in greater detail and, above all, essential information about the composition of the laminae that comprise macroscopically stratified contexts. The basic archaeological interpretations of the strata in the field have turned out to be true but without further information value. A comparison with ethnographic sources or with micromorphology applied to modern features, for which it was possible to describe the formational factors in detail, has shown that they are relatively different and, therefore, cannot be compared with the medieval contexts described so far. As yet, the survey has not answered the question of a possible functional classification of timber and earth basements.

\section{Kontakty}

Lenka Lisá

Geologický ústav AV ČR, v. v. i.

Rozvojová 269

CZ-165 00 Praha

lisa@gli.cas.cz

\section{Petr Holub}

Národní památkový ústav ÚOP v Brně

nám. Svobody 8

CZ-602 00 Brno

holub.petr@npu.cz

\section{Marek Peška}

Archaia Brno z. ú.

Bezručova 15

CZ-602 00 Brno

mpeska@archaiabrno.cz

\section{Antonín Zůbek}

Archaia Brno z. ú.

Bezručova 15

CZ-602 00 Brno

azubek@archaiabrno.cz 